Sandro Fortes da Silva Ramos

SEGURANÇA MARÍTIMA NO GOLFO DA GUINÉ: uma análise crítica sobre 0 processo de securitização da pirataria

Dissertação de Mestrado

Dissertação apresentada como requisito parcial para obtenção do título de Mestre pelo Programa de Pós-graduação em Relações Internacionais do Instituto de Relações Internacionais da PUC-Rio.

Orientadora: Profa. Adriana Erthal Abdenur 
Sandro Fortes da Silva Ramos

\title{
SEGURANÇA MARÍTIMA NO GOLFO DA GUINÉ: uma análise crítica sobre 0 processo de securitização da pirataria
}

\begin{abstract}
Dissertação apresentada como requisito parcial para obtenção do título de Mestre pelo Programa de Pós-graduação em Relações Internacionais do Instituto de Relações Internacionais da PUC-Rio. Aprovada pela Comissão Examinadora abaixo assinada.
\end{abstract}

Profa. prof Adriana Erthal Abdenur

Orientadora e presidente Instituto de Relações Internacionais - PUC-Rio

Prof. Carlos Frederico Pereira da Silva Gama Instituto de Relações Internacionais - PUC-Rio

Prof. André Panno Beirão

Escola de Guerra Naval

Profa. Monica Herz Vice-Decana de Pós-Graduação do Centro de Ciências Sociais - PUC-Rio

Rio de Janeiro, 13 de Março de 2015 
Todos os direitos reservados. É proibida a reprodução total ou parcial do trabalho sem a autorização da universidade, do autor e da orientadora.

\section{Sandro Fortes da Silva Ramos}

Bacharel em Direito pela Universidade Santa Úrsula (USU/2011) e Especialista em Relações Internacionais Contemporâneas pela Pontifícia Universidade Católica do Rio de Janeiro (PUC-Rio/2013).

Ficha Catalográfica

$$
\text { Ramos, Sandro Fortes da Silva }
$$

Segurança marítima no Golfo da Guiné : uma análise crítica sobre o processo de securitização da pirataria / Sandro Fortes da Silva Ramos ; orientadora: Adriana Erthal Abdenur. - 2015.

114 f. : il. (color.) ; $30 \mathrm{~cm}$

Dissertação (mestrado)-Pontifícia Universidade Católica do Rio de Janeiro, Instituto de Relações Internacionais, 2015.

Inclui bibliografia

1. Relações internacionais - Teses. 2. Golfo da Guiné. 3. Pirataria. 4. MEND. 5. Petróleo. 6. Complexo e subcomplexo regional de segurança. 7 . Securitização. 8. Dinâmica de segurança regional. I. Abdenur, Adriana Erthal. II. Pontifícia Universidade Católica do Rio de Janeiro. Instituto de Relações Internacionais. III. Título. 


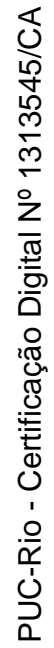

À minha companheira, Marina Berthet, e a nossa filha, Ayana Makeda. 


\section{Agradecimentos}

Em primeiro lugar, gostaria de agradecer ao Conselho Nacional de Desenvolvimento Científico e Tecnológico (CNPQ) por deferir o meu pedido no âmbito do Programa de Estudantes-Convênio de Pós-Graduação (PEC-PG) para ingressar no curso de Mestrado em Relações Internacionais da PUC-Rio. Agradeço, de igual modo, ao professor e Diretor do Instituto de Relações Internacionais - IRI-PUC-Rio - Dr. Paulo Luiz Moreaux Lavigne Esteves, que consentiu a carta de aceite para que eu fizesse parte do quadro discente da Instituição de Ensino Superior.

Meus agradecimentos também vão para todos os professores do Instituto de Relações Internacionais da PUC-Rio que, de forma direta ou indireta, contribuíram para a realização deste trabalho e se tornaram, no decorrer do mestrado, essenciais para a minha formação acadêmica e profissional. Ao professor Dr. Kai Michael Kenkel, meu orientador acadêmico, por ter me acompanhado desde a transição da pós-graduação (lato sensu) para o mestrado e por ter sido sempre solícito aos nossos encontros. A professora, e orientadora da dissertação, Dr. Adriana Erthal Abdenur, pelo incentivo e votos de confiança depositados no meu trabalho e também pelas dicas oferecidas para elaboração desta dissertação. Aos professores e professoras com os quais tive a oportunidade de aprender lições memoráveis: prof. ${ }^{a}$ Adriana Abdenur; prof. ${ }^{\text {a }}$ Carolina Moulin; prof. ${ }^{a}$ Marta Moreno; prof ${ }^{a}$.Monica Herz; prof. Fabiano Mielniczuk; prof. José María Gómes; prof. Nicolas Onuf; prof. Kai Kenkel; e prof. Roberto Yamato.

A todos os funcionários do IRI, pelo ambiente profícuo que me foi proporcionado todos os dias na Instituição, em especial, à Lia González, pela disponibilidade e atenção constantes.

Ao professor Alfa Oumar Diallo, da Universidade Federal de Grande Dourados, por acreditar no meu trabalho e no meu empenho em fazer o curso de mestrado. 
Ao professor Alain Pascal Kaly, da Universidade Federal Rural do Rio de Janeiro, e ao professor Mamadou Alpha Diallo, da Universidade Federal da Integração Latino-Americano, por aceitarem o meu convite para debater sobre o tema do meu trabalho e pelas sugestões propostas no quadro do meu projeto de dissertação.

À Casa das Áfricas, em especial a Presidente da Casa, professora e Dra. Denise Dias Barros, que me acompanhou na transição da graduação para o mestrado e que, por inúmeras vezes, se prontificou a ler o meu trabalho, quando ainda se tratava de um simples projeto inicial de pesquisa.

A todos os meus colegas da turma do mestrado (2013-2014), cujo apoio mútuo e amizade se confirmaram ao longo do curso. Pessoas com quem aprendi muito no decorrer dos debates propostos em sala de aula e das quais guardarei lembranças.

À minha família querida, principalmente, aos meus pais, irmãos e avó de Cabo Verde, por entenderem a minha ausência e acreditarem nos meus objetivos acadêmicos. Obrigado pelo apoio emocional incondicional.

A minha companheira querida, pelo amor e apoio integral durante todo o mestrado e por ter cuidado da nossa filha sozinha, enquanto eu elaborava esta dissertação.

Aos amigos do Rio de Janeiro, especialmente aos da Capoeira Angola, que embora sem entender o meu sumiço das rodas, sempre demonstraram carinho e solidariedade. Um especial agradecimento ao meu Mestre Manuel e ao Grupo Ypiranga de Pastinha.

Aos amigos de Cabo Verde, que incansavelmente mandam lembranças pelos familiares e continuam demonstrando o mesmo afeto e carinho de há quase dez anos atrás, quando saí do país para estudar no Brasil.

A todos vocês, meu muito obrigado! 


\section{Resumo}

Ramos, Sandro Fortes da Silva; Abdenur, Adriana Erthal. Segurança marítima no Golfo da Guiné: uma análise crítica sobre o processo de securitização da pirataria. Rio de Janeiro, 2015. 114 p. Dissertação de Mestrado - Instituto de Relações Internacionais, Pontifícia Universidade Católica do Rio de Janeiro.

Constatou-se que os atos piratas no Golfo da Guiné, especialmente em Nigéria, estão fortemente associados ao roubo de cargas de petróleo e à pilhagem das instalações de exploração do produto. As ações dos perpetradores de tais atos, como é o caso da Nigéria que se debruçou mais, visam atingir o Estado Federal e as multinacionais exploradoras do petróleo bruto nacional. Com base na "Teoria dos Complexos Regionais de Segurança" e nos conceitos teóricos sobre a securitização, procurou-se analisar a pirataria na região estudada como uma "ameaça existencial socialmente construída" e como um "objeto securitizado" por uma variedade de atores políticos (regionais e internacionais). O objetivo cabal é mostrar que, no atual contexto da corrida pelo petróleo no Golfo da Guiné, a "securitização" da pirataria provoca a "despolitização" de questões econômicas e sociais inerentes aos Estados locais e a ameaça suas soberanias e integridades territoriais.

\section{Palavras-chave}

Golfo da Guiné; Pirataria; MEND; Petróleo; Complexo e Subcomplexo Regional de Segurança; Securitização; Dinâmica regional de segurança. 


\section{Abstract}

Ramos, Sandro Fortes da Silva; Abdenur, Adriana Erthal (Advisor). Maritime security in the Gulf of Guinea: a critical analysis on the process of securitization of piracy. Rio de Janeiro, 2015. 114 p. Masters Dissertation - Instituto de Relações Internacionais, Pontifícia Universidade Católica do Rio de Janeiro.

It was found that pirates acts in the Gulf of Guinea, especially in Nigeria, are strongly associated with the theft of oil cargo and the pillaging of the product exploration installations. The actions of the perpetrators of such acts, as is the case of Nigeria which leaned more, aim to achieve the Federal State and the multinationals exploiting the national crude oil. Based on the "Theory of Regional Security Complex" and on the theoretical concepts of securitization, we tried to analyze piracy in the region studied as a "socially constructed existential threat" and a "securitized object" by a variety of political actors (regional and international). The full goal is to show that, in the current context of the race for oil in the Gulf of Guinea, the "securitization" of piracy causes the "depoliticization" of economic and social issues related to local states and threatens their sovereignty and territorial integrity.

\section{Keywords}

Gulf of Guinea; Piracy; MEND; Oil; Regional Security Complex and Subcomplex; Securitization; Regional security dynamic. 


\section{Sumário}

1. Introdução

2. Dinâmicas securitárias no Golfo da Guiné: a criação de um modelo de Complexos Regionais

Segurança a partir da securitização da pirataria

2.1 Apontamentos teóricos sobre o conceito de Complexo Regional de Segurança

2.2 A Comissão do Golfo da Guiné: o SubComplexo

Regional de Segurança da África centro-ocidental

2.3 O movimento securitizador da pirataria no Golfo da Guiné

2.4 Aspectos jurídicos sobre a pirataria e segurança marítima no Golfo da Guiné

2.4. 1 A proliferação das Companhias de Segurança Marítima Privada no Golfo da Guiné

3. Repensando a pirataria no Golfo da Guiné

3.1 A pirataria e a corrida internacional pelo petróleo do Golfo da Guiné

3.2 Estados fracos e pirataria no Golfo da Guiné

3.3 A pirataria no Golfo de Guiné e no Delta do Níger:

aspectos teóricos, econômicos e políticos

3.4 Insurgências e reivindicações políticas a partir do

Delta do Níger: O Movimento de Emancipação do Delta do Níger

4. Reflexões sobre ações adotadas na luta contra a pirataria

e a noção de segurança no Golfo da Guiné

4.1 A perspectiva francesa (e europeia) na questão

da segurança marítima no Golfo de Guiné

4.2 Breve apresentação da política de segurança norte-americana para a África centro-ocidental 
4.3 A governança na luta contra a pirataria: reflexões sobre o regionalismo africano

5. Considerações finais

6. Referências bibliográficas 


\section{Lista de Figuras}

Figura 1 - Mapa da arquitetura regional marítima do Golfo da Guiné 33

Figura 2 - Limites Marítimos 43

Figura 3 - Mapa da região do Golfo da Guiné 56

Figura 4 - Mapa das principais regiões e países produtores de petróleo 58

Figura 5 - Mapa dos Estados do Delta do Níger 62

Figura 6 - Mapa da produção de petróleo no Delta do Níger 68

Figura 7 - Mapa das Missões e ameaças identificadas 87 


\section{Lista de Tabelas}

Tabela 1: Dados do BMI sobre a pirataria em Nigéria (2011-2013) 


\section{Abreviaturas e Siglas}

AFRICOM. Comando dos Estados Unidos para África

BMI. Bureau Marítimo Internacional

CEEAC. Comunidade Econômica dos Estados da África Central

CEDEAO. Comunidade dos Estados da África Ocidental Econômica

CGG. Comissão do Golfo da Guiné

CIC. Centro Interregional de Cooperação

CNUDM. Convenção das Nações Unidas sobre o Direito do Mar

CRIMGO. Rotas Marítimas Críticas do Golfo da Guiné

CRS. Complexo Regional de Segurança

CSMP. Companhias de Segurança Marítima Privada

CSNU. Conselho de Segurança das Nações Unidas

JTF. Joint Task Force

MEND. Movement for Emancipation of Delta Niger

MOSOP. Movement for the Survival of the Ogoni People

MT. Mar territorial

NDDC. Niger Delta Development Commission

NDPVF. Niger Delta People's Volunteer Force

NDTC. Niger Delta Technical Committee

NN. Nigerian Navy

NNPC. Nigerian National Petroleum Corporation

NIMASA. Nigerian Maritime Administration and Security Agency

OMI. Organização Marítima Internacional 
R.I. Relações Internacionais

UA. União Africana

ZEE. Zona Econômica Exclusiva

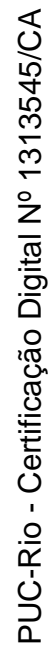




\section{1. INTRODUÇÃO}

A dinâmica securitária que perpassou as discussões, operações e decisões jurídicas da Comunidade Internacional ao tratar da pirataria nas costas somalis foi sem dúvida uma temática intrigante e que fez despertar a curiosidade para este estudo. Em menos de um ano, entre 2007 e 2008, as águas do Golfo do Áden e, consequentemente, as do Golfo de Guiné se tornaram mais conhecidas e temidas pela Comunidade Internacional - formada por membros como a Organização das Nações Unidas (ONU), o Conselho de Segurança das Nações Unidas (CSNU), a União Europeia (UE) e os seus Estados membros, os Estados Unidos, a China, etc. Um dos fatos que chamou atenção foi a posição do CSNU em relação à noção de segurança nestes dois espaços de importantes rotas do comércio marítimo internacional.

Neste mesmo fatídico 2008, diversos acontecimentos caracterizados por ataques violentos no mar e em terra na região do Golfo de Guiné mostraram que o fenômeno da pirataria no Golfo da Guiné não poderia ser mais considerado um epifenômeno da Somália. A quantidade de ataques e atos perpetrados desde o ano de 2008 até o final de 2014 no Golfo de Guiné, e o fato desse fenômeno ter sido construído como ameaça existencial por diversos atores internacionais e Estados regionais, foram elementos suficientes para que decidíssemos focar a atenção nessa temática. Rapidamente, e à medida que avançava o andamento das leituras, fomos levados a traçar um paralelo entre as ações políticas e militares ocorridas na região (conduzidas por países como França e Estados Unidos) e a corrida desenfreada pelo petróleo africano.

A análise do contexto sociopolítico e econômico do espaço onde ocorrem atos piratas no Golfo da Guiné se fez necessária para entender, por exemplo, as relações intraestatais marcadas por conflitos e problemas partilhados, as causas do aumento de atos de vandalismo e roubo nas águas internas dos países africanos da região. Além disto, tal análise colabora no entendimento a respeito de como o fenômeno da pirataria adquiriu novos significados.

Foi possível constatar a existência de um número acentuadamente maior de trabalhos e pesquisas que observam a pirataria como ameaça - avaliando suas causas e consequências - em detrimento de poucos estudos sobre os piratas, suas 
perspectivas e discursos. Diversas inquietações afluem neste cenário: os piratas roubam para o próprio enriquecimento? Para criar alternativas econômicas? Desestabilizar a ordem liberal? Defender alguma causa política?

"Eu defendo os direitos dos residentes privados da região do Delta que consideram que veem poucos benefícios do óleo extraído por baixo dos seus pés". Este trecho é de um dos discursos de Henri Okah - um dos ex-líderes do Movement for Emancipation of Niger Delta (MEND). Classificado como terrorista por alguns, como pirata por outros, considerado militante ativo do movimento por seus defensores.

Provavelmente, sua história - aqui brevemente resumida - não é representativa do que vive a maioria dos militantes que atuam na sombra e executam tarefas de soldados, implicados em operações de risco. Em fevereiro de 2008, a Nigéria acusa Okah de traição, terrorismo, tráfico de armas (etc.). O julgamento, em privado, ocorre meses depois, já que o então presidente Umaru Yar'Adua considera que um processo jurídico público ameaçaria a segurança nacional do país. Os advogados do réu contestam essa decisão, o MEND reage com ataque contra um oleoduto da Royal Dutch Shell. Um ano depois, Henri Okah escapa de uma possível pena de morte e aceita a anistia de 2009, concedida pelo presidente para os militantes dos diversos grupos armados da região do Delta. No dia 13 de julho de 2009, Henri Okah é liberado. O ex-militante volta a ser notícia nos jornais quando é novamente preso na África do Sul, tendo que responder a 13 acusações. Em poucas palavras, o veredito do juiz Nels Claassen resume-se no seguinte: "Chego a conclusão de que o Estado tem provado para além de qualquer dúvida razoável a culpabilidade do arguido". Henri Okah foi condenado a 24 anos de prisão. Seu percurso como militante foi midiatizado. Anistiado, nunca parou de defender as causas do MEND, que julga-se aqui, serem as causas de uma grande parcela da população do Delta.

Nesta dissertação, no marco cronológico compreendido entre os anos 2008 e o final de 2014, analisa-se o fenômeno da pirataria no Golfo de Guiné, e mais especificamente no Delta do Níger (na atual Nigéria), de forma distinta. No cerne deste trabalho consta a disputa pela posse e controle dos recursos petrolíferos entre uma gama de atores, o estudo das consequências da securitização da pirataria na região e a construção da arquitetura de segurança para a região marítima centro-oeste africana. 
Trata-se de um trabalho baseado no método qualitativo. Procurou-se coletar dados principalmente a partir da leitura de alguns romances e textos de escritores, artigos de Revista mensais (“Jeune Afrique” e o cotidiano nigeriano “The punch"), escuta de discursos, entrevistas de piratas, militantes e vozes de atores individuais ou das comunidades locais que constroem movimentos políticos alternativos ao Estado. Também revisitamos a análise de alguns discursos oficiais do CSNU, do governo francês e norte-americano. Livros e artigos acadêmicos foram utilizados para construir e defender alguns dos argumentos apresentados.

Dividiu-se o trabalho em três capítulos. O primeiro capítulo oferece um enquadramento teórico sobre a securitização e algumas dinâmicas securitárias no Golfo de Guiné. Apresenta-se um apontamento teórico sobre o conceito de Complexo Regional de Segurança, reflete-se sobre o movimento securitizador da pirataria na região e sobre o papel de um importante ator regional: a Comissão do Golfo de Guiné. Parte-se do princípio de que a Comissão pode ser interpretada como um Subcomplexo Regional de Segurança, envolvido em estratégias coletivas de segurança marítima regional. A questão da "extraversão" da política de segurança no Golfo de Guiné é também trabalhada e visa entender a participação de atores políticos internacionais implicados na luta contra a pirataria. Apresentamos ainda noções jurídicas de extrema relevância que corroboram a noção de securitização da pirataria.

No segundo capítulo dá-se prosseguimento a uma breve apresentação sobre as definições mais comuns da pirataria em Relações Internacionais, utilizase a perspectiva de ciências sociais para romper com a visão "superficial" e negativa dos piratas. Propõe-se ainda uma breve apresentação do contexto do Golfo da Guiné apontando para as relações entre a pirataria e a corrida internacional pelo petróleo da região. Em seguida, trata-se da questão dos "Estados fracos" e a pirataria, salientando a associação feita entre esses dois elementos. Exibe-se o contexto histórico e político do Delta do Níger, bem como as reivindicações políticas utilizadas por militantes que assumem a autoria dos roubos de carga de petróleo e atos piratas. Por fim, expomos algumas motivações e pretensões do Movimento de Emancipação do Delta do Níger e o contexto histórico no qual foi criado.

A noção de segurança perpassa as reflexões apresentadas nos capítulos anteriores. Descreve-se no terceiro capítulo algumas ações na luta contra a 
pirataria e visões dos atores envolvidos (Nigéria, França (e UE) e Estados Unidos). Procura-se evidenciar que essas visões se baseiam em elementos comuns: a noção de ameaça, o envolvimento na exploração e compra de petróleo, discursos que fazem referências a diferentes noções como segurança e insegurança, estabilidade e instabilidade, atos piratas e os riscos da desestabilização da ordem liberal. Questiona-se a apropriação do espaço político do Golfo de Guiné por parte de atores políticos internacionais e o papel dado aos países africanos na construção da segurança marítima regional. Encerra-se o capítulo com uma análise sobre o regionalismo africano, observando a questão da governança e da integração no que concerne ao combate à pirataria. 
2.

\section{DINÂMICAS SECURITÁRIAS NO GOLFO DA GUINÉ: A CRIAÇÃO DE UM MODELO DE COMPLEXO REGIONAL DE SEGURANÇA A PARTIR DA SECURITIZAÇÃO DA PIRATARIA}

O primeiro capítulo deste trabalho está orientado pela Teoria Clássica de Complexo Regional de Segurança (TCRS), que versa sobre determinados arranjos políticos entre Estados adjacentes, ou que compartilham ameaças em comum e, onde o processo de securitização e de desecuritização são frequentemente aludidos como exemplos de interação regional. Com esta, procurou-se desvelar o processo de securitização da pirataria em um determinado grupo de Estados da região marítima centro-oeste africana e entender por qual razão a pirataria é considerada uma ameaça existencial a ser securitizada pelos mesmos.

A partir da observação de uma série de noções teóricas consideradas cruciais para o entendimento das dinâmicas securitárias no espaço marítimo escolhido, obtivemos o aporte que nos auxiliou na abordagem do nosso objeto de estudo nos capítulos seguintes. Primeiramente, apresentamos alguns elementos teóricos que explicam o que é a securitização e evidenciam a sua prática - o movimento e ato securitizador. Em seguida, expomos alguns apontamentos teóricos sobre as espécies, formação e padrões dos Complexos Regionais de Segurança (CRS) para, na sequência, demonstrar a atuação da Comissão do Golfo da Guiné (CGG). Comissão definida no estudo como SubComplexo Regional de Segurança inserido no movimento securitizador da pirataria no Golfo da Guiné e que, entre seus maiores desafios tem a tarefa de lidar com a ingerência de vários atores extraterritoriais na política de segurança regional. Por último, procurou-se fornecer algumas noções jurídicas relevantes, que nos permitirá abalizar as proporções, limitações e consequências da securitização da pirataria na região marítima estudada.

Diante da necessidade de explicar o que afinal é a securitização, esclarecemos que, em primeiro lugar, se trata de uma abordagem "construtivista radical" criada no contexto dos estudos de segurança ${ }^{1}$. Buzan et al. (1998, p. 204),

\footnotetext{
${ }^{1}$ Os primeiros passos para a elaboração da teoria da securitização foram dados por Waever (1989) quando destacou o campo da prática da segurança e determinadas ferramentas que lhe eram peculiares, como por exemplo: o speech act (ato de fala) - conceito apropriado do campo da linguística. As ideias contidas em seu ensaio foram mais tarde aprofundadas em sua obra
} 
outrossim, a definiram como uma prática social ("social práxis", ibidem. p. 204) marcada por duas etapas: (1) a politização de uma determinada matéria (movimento securitizador) e (2) a despolitização da mesma matéria (ato securitizador).

Segundo Huysmans (2006, p. 47), na politização de determinadas matérias, o conjunto de unidades (grupos de Estados) passa primeiramente por um processo de distribuição do medo (criação de uma "comunidade política insegura") e por um procedimento de alienação, a partir da aceitação da ideia de que existe uma ameaça existencial que deve ser securitizada - sobretudo por meio de ações militarizadas. As percepções de ameaças, as preocupações compartilhadas e a construção de uma identidade política securitária entre os diferentes atores/unidades de uma determinada região, nesse sentido, funcionam como um movimento securitizador ("securitizing move").

Os próprios criadores das teorias sobre a securitização explicam que um dos primeiros critérios para que algo seja securitizado é precisamente a percepção intersubjetiva de ameaça existencial compartilhada (essencialmente em Complexos Regionais de Segurança ou Comunidades Regionais) e com saliência suficiente para produzir um efeito político (Buzan et al. 1998, p. 25). Disto decorre o entendimento da securitização como um processo intersubjetivo e socialmente construído (ibidem. p. 31).

O processo de securitização pode ser observado através do "ato de fala" (speech $\left.a c t^{2}\right)$. Os "atos de fala" são discursos, ou seja, práticas social e

"Securitization and Desecuritization" (1995), onde o autor retoma a sua análise ontológica e metateórica sobre o conceito de segurança, incorporando definitivamente o conceito de speech act e destacando a importância de aspectos intersubjetivos, emergenciais e excepcionais nas políticas de segurança. Algumas das reflexões mais categóricas desenvolvidas por Wæver (1995) foram posteriormente associadas às noções apresentadas por Buzan (1983; 1991), mais precisamente as sobre TCRS, que resultariam mais tarde em um sofisticado "framework" de análise para os estudos de segurança contemporâneos. Neste contexto, o Copenhagen Peace Research Institute (COPRI), criado em 1988, havia servido tanto como espaço de desenvolvimento criativo dos conceitos individuais desses autores quanto como espaço de convergência de um arcabouço coletivo. A obra "Security: A New Framework for Analysis" de Buzan, Wæver e Wilde (1998) é o resultado das análises teóricas e empíricas desses autores. Nesta obra são apontados questionamentos essenciais: (...) "quem securitiza, para quem, em que questão, porque, sob quais condições e com que resultado”. Para mais informações ver Buzan et al. 1998, p. 32.

${ }^{2} \mathrm{O}$ conceito de speech act é também trabalhado por Nicholas Onuf, um dos pioneiros do construtivismo social, em "Constructivism: A User's Manual” (1998), e em "Makingsense, makingword: constructivism in social theoryandinternationalrelations". New York: Routledge, 2013. O autor subdivide o speech act em três espécies: assertive speech act, directive speech act $\mathrm{e}$ commissive speech act. Conforme explica Onuf, é o speech act que dá forma às regras e às práticas sociais. Apesar da importância deste conceito, não cabe neste trabalho proceder a uma análise detalhada sobre o mesmo. Contudo, futuramente esta análise poderá ser aprofunda com o intuito 
culturalmente construídas. A multiplicação dos atos de fala, entre outros elementos, provocam um movimento securitizador que, em seguida, se transforma em um ato securitizador.

Buzan et al. (1998, p. 26-27) lembram que quando se expressam sentidos ligados à ideia de segurança - mesmo que a palavra segurança não seja mencionada - significa que o ator que pronuncia a ideia quer dizer: "algo deve ser feito". Se, por exemplo, algum ator político internacional expõe o fato de que piratas na costa ocidental africana têm dificultado a exploração e o comércio de petróleo local - embora não seja mencionada a palavra segurança - isto significa que alguma providência de imediato deve ser tomada. Não importando se tratar de reivindicações políticas, corso ou pirataria de fato.

Conforme explicam Buzan et al. (1998, p. 204), o "ato de fala" leva os atores a inserir questões do campo de segurança em discursos e debates políticos, com intuito de ganhar a aceitação da audiência e assim angariar legitimidade para suas ações em contexto de "segurança extraordinária". Politizar um tema, construí-lo como objeto ameaçante e formar opiniões a favor de intervencionismo militar faz parte de uma estratégia construída a partir de discursos ou atos de fala.

No entanto, conforme o framework da securitização, a existência de discursos - que constroem uma ameaça existencial ou apontam para objetos de referência - não cria, ou não é "suficiente", para que seja constatada a securitização propriamente dita. A ameaça existencial é efetivamente securitizada somente a partir da aceitação de uma audiência relevante (as elites e atores políticos em geral) que, em seguida, legitima o ato securitizador (ibidem. p. 25). Daí a importância da audiência ou auditório que, embora não participe do ato securitizador propriamente dito, é extremamente importante para a efetivação do processo de securitização como um todo.

Depois da primeira etapa da securitização - a politização ou o movimento securitizador - temos uma etapa que é trabalhada somente pelos profissionais e experts em segurança, e que está fora do âmbito público. Alguns trechos da explicação de Buzan et al. (1998), enfatizando as nuances do processo de

de buscarmos uma melhor compreensão do processo através das quais determinadas questões são definidas e construídas como ameaças existenciais em regiões, comunidades e unidades específicas. 
securitização, são apresentados aqui com o objetivo de ilustrar a distinção entre a politização e a despolitização, isto é, entre o movimento e o ato securitizador.

\begin{abstract}
Although in one sense securitization is a further intensification of politicization (...), in another sense it is opposed to politicization. Politicization means to make an issue appear to be open, a matter of choice, something that is decided upon and that therefore entails responsibility, in contrast to issues that either could not be different (laws of nature) or should not be put under political control (...). By contrast securitization (...) means to present an issue as urgent and existential, as so important that it should not be exposed to the normal haggling of politics but should be dealt with decisively by top leaders prior to other issues. (Buzan et al.,1998, p. 29, grifos meus)
\end{abstract}

Por conseguinte, a segunda etapa da securitização (o ato securitizador) é apreendida pelos pesquisadores da escola dinamarquesa como um processo gradual de despolitização. Dessa forma, uma vez que o tema foi exposto ao público ou audiência, este passa a não fazer mais parte do debate público e tornase assunto exclusivo dos atores/agentes securitizadores ${ }^{3}$.

Este é o estágio mais problemático na prática do processo de securitização. Dado que, as medidas tomadas no ato securitizado - ou seja, após a aceitação da audiência - dispensam justificativas para ações que saem da esfera de "política normal", passam a fazer parte de questões de segurança máxima e são consequentemente transferidas para uma agenda de "política de pânico" (Buzan et al., 1998, p. 23-24 e p. 34). Certamente, é por isto que os autores da escola dinamarquesa argumentam que a securitização não necessariamente deve ser vista como algo positivo. Muitas vezes ela pode significar uma falha na resolução de questões dentro da esfera "política normal" (ibidem. p. 29). Circunstância que, no caso de estudo apresentado, mostra-se ainda mais crítica devido a um aspecto fundamental: a securitização e a despolitização de questões regionais por parte de atores externos (internacionais).

Conforme Fierke (2007, p.108), esta etapa da securitização - marcada pela suspensão da ordem política normal (despolitização) - é baseada na concepção política de Carl Schmitt, caracterizada pelo binômio amigo/inimigo e intimamente relacionada com a "teoria da soberania decisionista" e a política de exceção. Fierke explica que o ato da soberania, neste caso, passa a ser: “(...) the ability to

\footnotetext{
${ }^{3} \mathrm{O}$ ator securitizador ("securitizing actor") é aquele que promove a securitização de uma determinada matéria, anunciando um objeto referente como existencialmente ameaçado (Buzan et al., 1998, p. 36).
} 
decide when a threat to the prevailing political order has reached a point where it constitutes an emergency, thereby requiring the suspension of the normal rules and procedures to the end of preserving political order" (Fierke, 2007, p.109).

A autora citada lembra ainda que a suspensão da ordem política normal, em algumas situações, pode se tornar um "estado de exceção permanente", onde o soberano schmittiano tem a prerrogativa de obstruir os direitos civis ao impor poderes excepcionais e utilizar tecnologias de controle governamental (Fierke, 2007, p. 116). Revisitando ideias de Foucault, Fierke explica que o poder da soberania passa a se resumir em uma espécie de governança da população, da sua vida biológica (“biopolítica”) e não exatamente da sua vida política/jurídica (ibidem. p. 116). A autora insinua que, nesse caso, ocorre um abuso da autoridade que ultrapassa os limites do exercício do poder.

Por sua vez, Neocleous (2008, p. 55), com um olhar crítico sobre as práticas de segurança contemporâneas, mostra como estas podem ressignificar conceitos como: democracia, liberalismo e paz liberal. Em seu trabalho, o autor desvela que a segurança, em determinados casos, consiste muito mais em estabelecer uma ordem democrática liberal do que em proteger-se de um inimigo ou ameaça existencial. Destarte, alguns Estados vivem atualmente em um "estado de emergência permanente", onde a lei marcial se sobrepõe e toma conta das suas realidades. Conforme Neocleous, a segurança se torna então uma forma de opressão, e não uma prática cuja função seja garantir a liberdade dos indivíduos. $\mathrm{O}$ autor explica que as práticas de segurança - permeadas pelo espírito neoliberalista - podem até garantir a segurança de fato, mas não a liberdade dos cidadãos. Adverte, então, que segurança e liberdade não são antônimos e, para evitar condutas autoritárias e absolutistas justificadas em nome da segurança, sugere a redefinição do conceito de segurança - que poderia ser compreendida como uma prática indissociável ao princípio da liberdade dos indivíduos.

Para ilustrar o problema da separação dos dois conceitos trabalhados por Huysmans (2006) - segurança e liberdade -, no caso do Golfo da Guiné aqui em estudo, sinalizamos o fato de que indivíduos locais exercendo suas atividades, como pescadores, muitas vezes são molestados nas operações militares (seja nacional, bilateral ou internacional), em pleno exercício de suas profissões, sob suspeita de pirataria. Estes fatos não são relatados pelas instituições regionais e internacionais e não podem ser quantificados aqui. Além disto, ocorrem em 
operações que têm algum respaldo legal e que, a princípio, não devem ser questionadas.

Todavia, a escalada da violência entre militares e grupos de indivíduos armados no Golfo da Guiné, como perceberemos mais adiante, não é nada trivial e tende-se a perpetuar. Fica claro que uma operação conjunta tão somente militar para combater a pirataria no Golfo da Guiné é ineficiente. A pirataria na região marítima se desponta como complexa o bastante para ser tratada somente na esfera do setor militar. É também necessário pensar em práticas de segurança que considerem as motivações em vários setores: político, econômico, social e ambiental. Pois, como bem lembra Ullman (1983, p. 130) definir a segurança nacional apenas em termos militares transmite uma falsa imagem da ordem política mundial. E, o uso exclusivo dos meios militares para garantir a segurança acaba por reduzir a percepção de total segurança.

Talvez seja por isto que alguns pesquisadores tentaram propor soluções para remediar esse tipo de situação. Em certos casos, como explicam os autores da Escola de Copenhague, é mais profícuo pensar em "desecuritizar", isto é, trazer a questão securitizada para o âmbito da política normal (Buzan et al. 1998, p. 4). Ou então, como sugere o sociólogo Huysmans: "desconstruir o processo de produção de ameaça/insegurança" (Idem, 2006, p. 125) para garantir que a questão volte a ser discutida em setores não militares, notadamente os setores social, político e econômico. Os debates sobre matérias já securitizadas podem tornar-se públicos, democráticos e mais responsáveis. O que para Huysmans (Idem, 2006, p. 127) é também uma importante estratégia de realocação de questões para o contexto de um "julgamento ético-político", onde o imaginário político baseado no conceito schmitteano é eliminado e a desecuritização é pensada como forma de criar práticas alternativas para as políticas de segurança.

A desecuritização, bem como o processo de securitização de objetos de referência, é sempre mais saliente nos Complexo Regional de Segurança. Por isto, na próxima seção procedemos a uma sucinta apresentação do conceito de CRS para então demonstrar algumas dinâmicas do SubComplexo Regional de Segurança escolhido para análise: a Comissão do Golfo da Guiné. 


\section{1 \\ Apontamentos teóricos sobre o conceito de Complexo Regional de Segurança}

A Teoria Clássica de Complexo Regional de Segurança (TCRS), criada por Buzan em 1991, permitiu analisar dinâmicas e questões de segurança internacional na Europa e em outras regiões do mundo, em épocas diferentes, a partir de uma abordagem regional. Buzan e Waever perceberam que após a Guerra Fria as questões de segurança estavam muito mais atreladas a algumas regiões geográficas específicas do que ao sistema internacional como um todo com um pormenor habitual que é a interferência de atores internacionais nas dinâmicas regionais. Assim criaram um quadro de análise que pudesse alcançar um melhor diagnóstico da nova realidade securitária e política mundial.

Segundo Buzan et al. (2003) esta abordagem se baseia em um nível de análise intermediário (situada entre os estudos de segurança nacional e internacional), podendo ser considerada uma abordagem abrangente por levar em conta os elementos dos diferentes níveis de análise, com enfoque na relevância de variáveis internacionais, regionais e locais.

$\mathrm{Na}$ construção da TCRS, Buzan e Waever consideraram que as questões de segurança deveriam ser determinadas primeiramente por quesito geográfico e se inspiraram, em parte, nos sistemas regionais, regimes de segurança e comunidades de segurança para pensar os CRS. Com efeito, os autores consideram que a interação regional e o grau de ameaça/medo que sentem dois ou um grupo de Estados configuram os elementos principais utilizados para explicar a formação de um CRS. Segundo Buzan (1991, p.190, 193-194) e Buzan et al. (1998, p.12), a noção de CRS remete a um conjunto de Estados em que a maioria das percepções e preocupações de segurança estão tão interligadas que seus problemas de segurança nacional não podem mais ser razoavelmente analisados ou resolvidos de forma independente dos demais. Com esta definição, entende-se que a questão da interdependência existe quando Estados vizinhos partilham as mesmas ameaças e se inscrevem em padrões de relacionamentos amizade/inimizade (Buzan, 1991, p.118-190).

Ao longo dos anos e das pesquisas realizadas, a TCSR foi paulatinamente sendo aperfeiçoada e adaptada às realidades de cada região. Inicialmente o Estado era considerado o ator principal, senão o único, de um Complexo Regional de 
Segurança. Uma década depois, o CRS passa a ser caracterizado como um conjunto de unidades, no qual o Estado é apenas um dos atores relevantes do contexto regional ${ }^{4}$. Outra mudança fundamental nos estudos dos CRS é a inclusão de temas vinculados a setores não-militares para a análise da realidade sociopolítica. Com base em uma perspectiva construtivista, Buzan et al. (1998) introduziram outros setores (político, social, econômico e ambiental) considerados chaves para análise de dinâmicas de segurança. Os CRS assumem então a seguinte definição: "conjunto de unidades cujos processos principais de securitização e desecuritização (ou ambos) são tão interligados que seus problemas de segurança não podem ser analisados de maneira separada” (Buzan e Waever, 2003, p.44). Esta definição vale também para os "SubComplexos Regionais de Segurança” incorporados a grandes CRS. A ideia de SubComplexo é interessante, porque apesar de estar inserido dentro de um Complexo Regional de Segurança maior, possui características e dinâmicas próprias. O critério para distinguir o Complexo e o SubComplexo resume-se a uma questão de tamanho. Isso significa que os elementos apresentados para o uso de CRS na análise de dinâmica de política de segurança podem ser utilizados também para a análise do SubComplexo Regional de Segurança (SubCRS).

É válido trazer a constância da variável "proximidade geográfica" elemento trabalhado pelos pesquisadores da escola dinamarquesa, citada anteriormente. Em trecho do livro Regions and Powers: the structure of International Security (2003), Buzan et Wæver valorizam o elemento de proximidade e sua relevância para a análise da questão securitária: “A contiguidade aumenta mais a interação em termos securitários do que em termos econômicos" (2003, p. 45). Esses autores propõem outro elemento para construir a teoria de CRS: uma tipologia de CRS que permita levar em consideração a lista heterogênea de CRS existente. Destaca-se o CRS centrado (com variáveis) e o CRS padrão. O primeiro se define pela existência de um poder centralizado: unipolar (tendo uma potência ou uma superpotência como polo) ou então com um poder entre diferentes instituições (sem poder regional). O segundo tipo é o CRS padrão, com seu poder definido por diversos atores regionais, não tendo uma

\footnotetext{
${ }^{4}$ Buzan e Wæver (2003, p. 45) afirmam que, embora existam atualmente outros atores com a capacidade de afetar a dinâmica de um sistema securitário, o Estado é uma referência nacional/internacional e não deve ser descartado na análise do sistema regional.
} 
potência centralizadora. É o caso do chifre da África e da África austral, para nos limitarmos a exemplos do continente africano.

Os autores da Escola de Copenhague definiram também as relações que formalizam a estrutura e funcionamento de um CRS. Isto é: (1) distribuição de poder entre os Estados da região (âmbito geográfico); (2) padrões de "amizade/inimizade" em diferentes setores - mencionados acima - e entre diferentes unidades/atores e, por fim, (3) interferência do sistema global nas relações de poder entre atores regionais e atores internacionais (entenda-se aqui principalmente as superpotências globais).

Quando Buzan e Waever (2003, p.445 e 446) aplicaram a TCRS, se debruçaram sobre diversas estruturas regionais e identificaram um total de onze $\mathrm{CRS}^{5}$ no mundo que seguem o padrão de relacionamento "amizade/inimizade", com três categorias distintas: formações conflitais; regimes de segurança; comunidades de segurança. Esse estudo foi comentado e criticado por outros autores.

Apontando para alguns limites da TCSR, Balzacq (2007, p.39-40) McSweeney (1999, p.63) avaliam que o uso dos "padrões de relacionamento" simplifica as relações que ocorrem num CRS. Para o primeiro autor é primordial usar esse conceito, porém, complementando-o com as noções de "diferenciação", "alteridade" e "distanciamento estratégico" para considerar a complexidade das situações vividas na região ${ }^{6}$. Constatamos que o uso deste binômio limita a compreensão do jogo político da região estudada. Isto é, considerar a competitividade pela liderança, a multiplicidade dos atores e as diversas relações que se estabelecem e se transformam, ou ainda, o significado dos acordos bilaterais e sua importância na captação de recursos.

Outra crítica avançada em relação ao uso da tipologia do CRS é a questão dos regimes e comunidades de segurança. Deutsch et al. (1957), Adler e Barnett (1998, p. 3-65) e McSweeney (1999, p. 63) ${ }^{7}$ são autores imprescindíveis sobre a questão. McSweeney, por exemplo, avaliou que a ideia inicial de Buzan e Waever

\footnotetext{
${ }^{5}$ América do Norte; América do Sul; Europa (pós-URSS); Oriente Médio; África Ocidental; África Central; Chifre da África; África Austral; Sul da Ásia; Leste Asiático.

${ }^{6}$ Wolf $(2007$, p.77) sugere que a noção de insiders/outsiders pode ser associada ao binômio amizade/inimizade para que a análise das relações possa apreender as relações complexas entre unidades que se estabelecem na região.

${ }^{7}$ Little, Krashner e Baylis também trabalharam essas noções evidenciando o papel dos Estados, sua cooperação para eliminar o dilema segurança.
} 
é sugerir um tipo de continuum ou "evolução linear" com duas extremidades: o caos por um lado e a comunidade de segurança por outro. Para os autores da Escola de Copenhague, a guerra é inconcebível dentro de uma comunidade de segurança (exemplo: a União Europeia) e os conflitos se resolvem sem violência. O que levaria Buzan a considerar que as "comunidades de segurança são complexos regionais de segurança maduros" (1991, p.115).

A ideia de McSweeney e corroborada aqui, partindo da suposição de que a análise de Buzan no fundo está baseada em uma evolução linear, que conclui que na Europa existem "complexos maduros" enquanto na África existem apenas "protocomplexos regionais de segurança". Dentro dos complexos de segurança africanos, Buzan constata o potencial de violência presente, que pode ser utilizado para resolver um conflito dentro do CRS. O autor sublinha a persistência dos conflitos intra e interestatais, entre centro e periferia, com muitas restrições, como regras, normas, etc. $\mathrm{O}$ que faz com que dificilmente um CRS se torne um regime de segurança ou uma comunidade de segurança. Um dos limites da TCRS de Buzan et al. (2003) é portanto a ideia "evolucionista" na qual temos "o caos" por um lado e "a comunidade de segurança" por outro.

Apesar dos limites apresentados acima, considera-se que os conceitos de CRS e SubCRS foram conspícuos para o entendimento das dinâmicas políticas em torno da questão de segurança no Golfo de Guiné. Na próxima seção, baseando-se na TCRS, apresenta-se um desenho da arquitetura de segurança do Golfo da Guiné, focado na análise da atuação de um dos conjuntos de unidades mais proeminentes da região marítima estudada. Esta análise nos possibilitará uma melhor compreensão do movimento securitizador em torno da pirataria no seu espaço marítimo.

\section{2}

\section{A Comissão do Golfo da Guiné: o SubComplexo Regional de Segurança da África centro-ocidental}

Para Buzan e Waever, a África subsaariana é dividida em quatro CRS. O primeiro - a África austral, é um CRS consolidado (2003, p. 233-238) enquanto o chifre da África e a África ocidental (p. 241-243) são "protocomplexos" e a África central um Complexo em estruturação (p. 243-247). Outras áreas, ou seja, países, 
(por sinal, situados no Golfo de Guiné) são considerados "insulares" nas dinâmicas inter-regionais.

Os autores supracitados consideram que a África ocidental se caracteriza como um espaço geopolítico no qual ocorrem diversas mazelas (entre conflitos domésticos e presença de rotas de diferentes tráficos), mas sem padrões regulares de interação de segurança. A região encontra-se assolada por diversos conflitos interestaduais e intraestaduais ${ }^{8}$ - fator chave para caracterizar o CRS - e por ameaças semelhantes, se comparamos os Estados vizinhos da região, que comportam enormes repercussões regionais. Uma dessas ameaças é a migração e deslocamento de refugiados para além das fronteiras estatais. Esses deslocamentos são consequências diretas de conflitos internos, condições de vida etc. e, conforme Herz (2005, p.1), devem ser resolvidos em âmbito regional.

Além da CGG, cabe mencionar que a região do Golfo da Guiné possui instituições regionais de peso que merecem ser destacadas: a Comunidade Econômica dos Estados da África Ocidental ${ }^{9}$ (CEDEAO ou ECOWAS) existente desde 1975; a Comunidade Econômica dos Estados da África Central (CEEAC) criada em 1985. Essas duas comunidades regionais são constantemente citadas na questão da dinâmica e arquitetura de segurança da região. A $\mathrm{CEDEAO}^{10}$, por exemplo, é apontada por Buzan et al. (2003) como o conjunto de unidades mais complicado no "ProtoComplexo de Segurança Oeste africano", em razão da existência de "microcomplexos sub-regionais" que possuem dinâmica própria. O autor se refere às dinâmicas operadas por atores subnacionais (exemplo: grupos insurgentes), nacionais (exemplo: Estado) ou transnacionais (exemplo: grupos ligados ao terrorismo ou crime organizado) e extrarregionais (exemplo: os EUA, o Reino Unido e a França). Essas duas instituições já foram objetos de pesquisa

\footnotetext{
${ }^{8}$ Os Estados da região se caracterizam por certa instabilidade política, que ocasiona tentativas de golpes de Estado, guerras civis, degradação das condições de vida. Cabo Verde e Senegal são as duas exceções.

${ }^{9}$ Desde a saída da Mauritânia a CEDEAO é formada por quinze Estados: Benim; Burkina Faso; Cabo Verde; Costa do Marfim; Gâmbia; Gana; Guiné; Guiné Bissau; Libéria; Mali; Níger; Nigéria; Senegal; Serra Leoa e Togo.

${ }^{10}$ Alguns autores (Cepik, 2005 e Diallo, 2012) discordam de Buzan e Waever quando estes afirmam que na ausência de interações securitárias significativas, a África do Oeste sequer poderia ser considerada pré-complexo de segurança. Segundo os autores, o CRS não implica a presença de uma organização regional. Contudo, no caso da CEDEAO, se essa foi originalmente criada para ser uma comunidade econômica, a instituição se destacou nesses últimos anos no campo da segurança, principalmente através da Economic Community of West African States Monitoring Group - força militar multilateral oeste-africana, estabelecida pela CEDEAO e que interveio na Libéria e Serra Leoa (ECOMOG).
} 
com foco na segurança regional, operações de paz, etc. Contudo, salvo engano, localizamos pouquíssimos elementos e reflexões sobre o papel da CGG no desenvolvimento de uma estratégia de segurança regional. Por essa razão, julgamos oportuno apresentar brevemente as diferentes etapas constitutivas dessa Comissão e em seguida, explicar por que a CGG foi definida neste estudo como um SubComplexo Regional de Segurança.

É importante saber que, inicialmente a $\mathrm{CGG}^{11}$ representava o órgão responsável por facilitar consultas na sub-região, prevenir, gerir e resolver os conflitos que poderiam surgir da demarcação de fronteiras marítimas e na exploração econômica e comercial dos recursos naturais dentro das fronteiras marítimas dos seus países membros ${ }^{12}$. A resolução de conflitos interestaduais, a gestão dos recursos petrolíferos e a definição de estratégias para o desenvolvimento econômico do Golfo eram os objetivos centrais que norteavam seu funcionamento. Ao mesmo tempo, questões sobre segurança ou crimes marítimos não faziam parte de sua agenda de órgão regional. Isso significa que seus Estados membros não haviam desenvolvido bases e diretrizes para uma estratégia concreta de cooperação regional no âmbito da segurança marítima.

Nessa circunstância, a CGG, após o início do seu funcionamento (em 2008), se defrontou com um grande desafio: manter a segurança e a ordem no seu espaço marítimo. Isto é, mitigar os crimes organizados, assaltos à mão armada e sequestros às embarcações comerciais e petrolíferas estrangeiras que se tornavam crescentes na região. Foi a partir de então que, progressivamente, a Comissão passou a priorizar questões ligadas à segurança marítima e energética, participar de reuniões e conferências sobre o assunto e tornou-se reconhecida por outros atores como instituição com papel regional promissor.

Pressionada pelas denúncias internacionais sobre os atos ilícitos ocorrendo nos mares do Golfo da Guiné, a CGG começa então a elaborar um novo plano político em torno da segurança marítima e energética. Isto posto, a Comissão juntava os principais Estados produtores de petróleo locais e os maiores interessados na segurança marítima e energética da região e, sem esquecer,

\footnotetext{
${ }^{11}$ São membros fundadores da Comissão africana: Angola, Camarões, Congo (Brazzaville), Congo (Kinshasa), Gabão, Guiné Equatorial, Nigéria e São Tomé e Príncipe. Para mais informações consultar: http://www.revistamilitar.pt/artigo.php?art_id=797. Acesso em: 03/05/2014.

${ }^{12}$ Informações disponíveis em: http://www.ggcn-rcgg.org/spip.php?article58. Acesso em: $17 / 06 / 2014$
} 
tratava-se de um quesito onde a responsabilidade primária pertencia à Comissão.

O plano político traçado pelo então novo presidente da CGG, José Eduardo dos Santos, parecia coincidir com a circunstância específica do Golfo da Guiné, que passara a ser integrado à agenda de segurança energética de vários países estrangeiros e multinacionais. Em 2008, conforme Joveta José (2011, p. 255), ocorreu a segunda Cimeira de Chefes de Estado do Golfo da Guiné, em Luanda, ocasião em que o presidente de Angola assumiu efetivamente a presidência da CGG com o compromisso de tornar a sub-região africana um espaço de relevância geopolítica, geoeconômica e geoestratégica no cenário da África central e continental.

$\mathrm{O}$ aspecto regional da luta contra a pirataria se tornou efetivo a partir das declarações da CGG nesta mesma altura. Em diversas ocasiões e conferências a CGG confirmou seu interesse em participar de maneira ativa na luta contra a pirataria no seu espaço marítimo. Assim o fez durante a terceira Cimeira de Chefes de Estado - organizada após as resoluções do CSNU, realizada nos dias 24 e 25 de junho de 2013 em Yaundé (Camarões). $O$ foco dado à segurança marítima cooperativa e coletiva para lutar contra os atos ilícitos dos mares do Golfo da Guiné retratou a preocupação dos países da região ${ }^{13}$.

Na ocasião, a CGG ratificou o pedido de inclusão na sua Comissão para três países africanos do Golfo da Guiné (Gana, Costa do Marfim e Libéria ${ }^{14}$ ) com o objetivo provável de alcançar uma nova performance na atuação da Comissão. A CGG passou a representar uma voz conciliadora e relevante no tabuleiro da cena política regional do Golfo, contando com a participação e apoio de outras instituições e Estados (regionais e internacionais). José Eduardo dos Santos, no contexto da cúpula de chefes de Estados citada, ainda enfatizou o fato de que a luta contra a pirataria é uma luta internacional: "É necessário estabelecer-se uma conjugação de esforços mais eficazes entre os países da África Central e Ocidental, da União Africana, do Atlântico Sul e das Nações Unidas"15.

\footnotetext{
${ }^{13}$ Declaração de Chefes de Estado e de Governos da África Central e Ocidental sobre a Segurança Marítima no Domínio Marítimo Comum. Documento disponível em: http://www.ecowas.int/publications/en/maritime_security/declaration.pdf. Acesso em 10/02/2014. ${ }^{14}$ Informação disponível em: http://www.angola.org.uk/press/en/press_releases/3rd_Summit_Meeting_Of_Heads_Of_State_An d Government.htmlAcesso em: 15/02/2014.

${ }^{15}$ Para mais informações consultar: http://www.dnoticias.pt/actualidade/mundo/400816-presidenteangolano-elogia-comissao-do-golfo-da-guine-no-combate-ao-crime-n Acesso em: 23/07/2014
} 
Em outra conferência dos chefes de Estado da CGG, realizada em Malabo (Guiné Equatorial) em agosto de 2013, um dos maiores desafios estabelecidos para a CGG foi criar uma estratégia baseada em "instrumentos próprios africanos" e desenvolver uma segurança coletiva entre os países africanos desta região com base nas orientações da União Africana (UA), sugeridas em dezembro de 2012. Criou-se o plano chamado: “Africa Integrated Maritime Strategy" (2050 AIM Strategy) para: “assegurar a promoção da paz, segurança e estabilidade no espaço marítimo do Golfo da Guiné pela mobilização de meios operacionais institucionais e logísticos" e "garantir a circulação de bens e das pessoas"16.

Outras decisões tomadas durante a conferência estão todas vinculadas à questão da segurança marítima. Os diferentes chefes de Estados membros da CGG reunidos na ocasião decidiram pelas seguintes ações:

- Criação de um memorando sobre a segurança nos espaços da África Ocidental e Central;

- Adoção de um código de conduta relativa à prevenção e repressão dos atos piratas;

- Criação de um centro inter-regional de segurança marítima na África central e ocidental (CIC) ${ }^{17}$.

Em comunicado final ${ }^{18}$, os chefes de Estado da CGG reiteraram sua preocupação com "as graves ameaças" relacionadas à pirataria, roubos, atividades marítimas ilícitas militares e outros crimes no Golfo da Guiné e congratularam o Conselho de Segurança da Nações Unidas (CSNU) pela aprovação das Resoluções (Res. 2018 (2011) ${ }^{19}$ do 31/10/2011 e Res. 2039 (2012) ${ }^{20}$ do 29/02/2012) e a União Africana pela sua estratégia integrada para os mares e oceanos (se referindo ao AIM strategy 2050).

\footnotetext{
16 Informação disponível em: http://gabonreview.com/blog/les-decisions-du-sommet-sur-lapiraterie-maritime-de-yaounde/ Acesso em:23/04/2014

http://www.portalangop.co.ao/angola/pt pt/noticias/politica/2013/7/32/Conselho-Ministrosadopta-relatorio-para-aprovacao-Cimeira,bdd23b88-b751-4352-9119-f55e7a24bb31.html Acesso em: 22/07/2014

${ }^{18}$ Communiqué Final du Sommetdes Chefs d'Etat et de Gouvernement de La Communauté Economique dês Etats de l'AfriqueCentrale (CEEAC), de La CommunautéEconomique dês Etats de l'Afrique de l'Ouest (CEDEAO) et de La Commissiondu Golfe de Guinée (CGG) surlaSûreté et La SécuritéMaritimesdansle golfe de Guinée.

${ }^{19}$ Documento disponível em: http://www.securitycouncilreport.org/atf/cf/\%7B65BFCF9B-6D274E9C-8CD3-CF6E4FF96FF9\%7D/UNOWA\%20S\%20RES\%202018.pdf.Acesso em 05/01/2014.

${ }^{20}$ Documento disponível em: http://unscr.com/files/2012/02039.pdf. Acesso em 05/01/2014.
} 
A pirataria, por conseguinte, foi sendo uma ameaça "autorreferida" pela CGG desde 2008. Mas é em 2012/2013, principalmente a partir das resoluções do CSNU, que a Comissão passa a expor as suas percepções intersubjetivas compartilhadas entre os seus membros para a mídia (local e internacional) e a salientar a necessidade de conjugação de esforços entre atores regionais e extra regionais para assolar o fenômeno da pirataria no seu espaço marítimo.

No mapa a seguir, pode-se observar a configuração da "arquitetura regional de segurança" e as áreas de atuação de algumas instituições regionais que cooperam constantemente com a CGG. Diversas instituições regionais (CGG é destacada em cor roxa, o CIC (ou ICC), a CEDEAO e a CEEAC) participam desta estratégia de segurança marítima conduzida pela CGG. A CEDEAO e a CEEAC são as principais atrizes do processo de estruturação e luta contra a pirataria. Cada uma delas é responsável por setores (A, B, etc.) dentro de uma região que se encontra sob sua administração. Os setores E e F se encontram na região da África do oeste, onde a CEDEAO também atua.

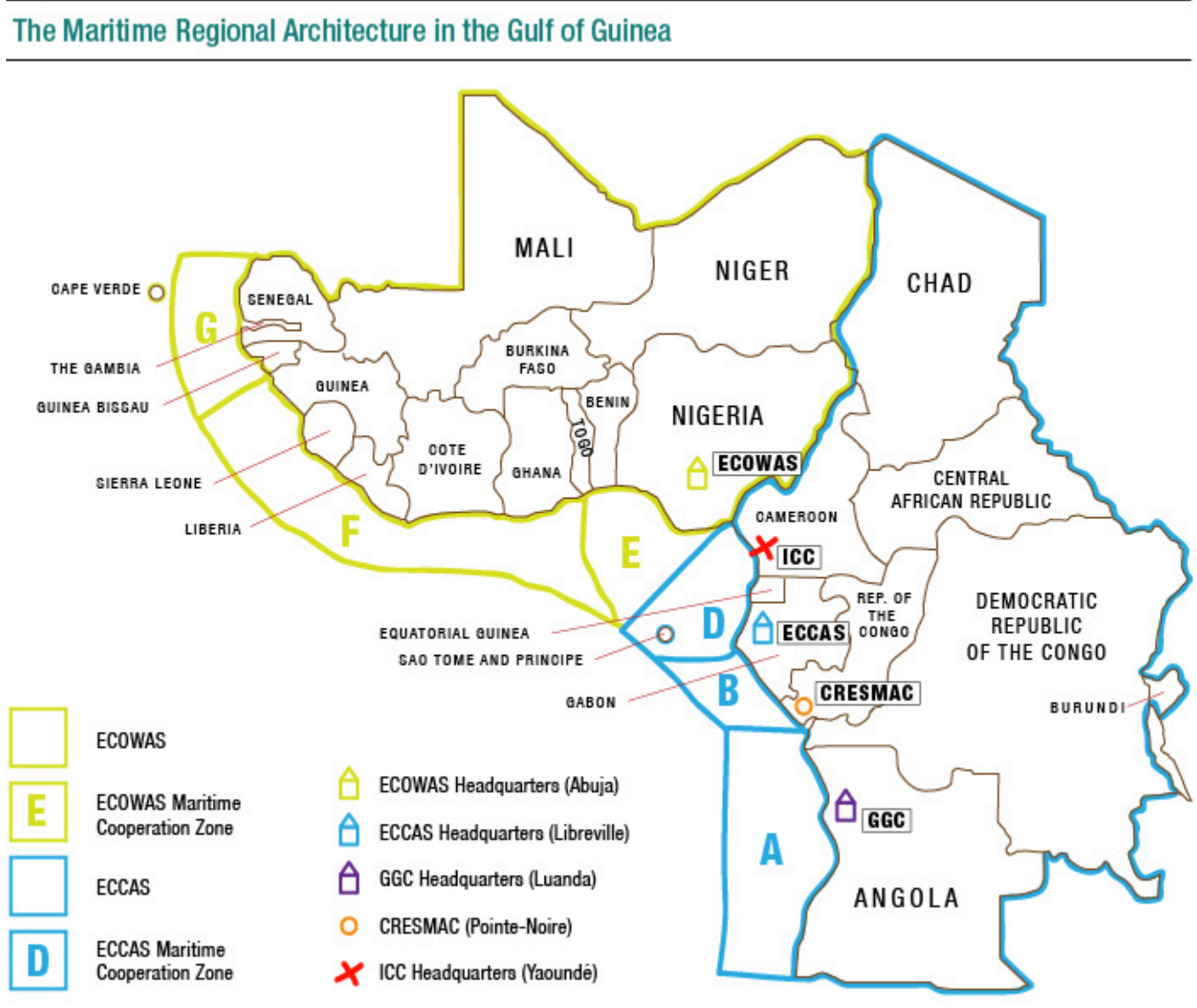

Figura 1: Mapa da arquitetura regional marítima do Golfo da Guiné.

Fonte: Internacional Crisis Group. Disponível http://blog.crisisgroup.org/africa/2014/09/04/gulf-of-guinea-a-regional-solution-to-piracy/ 
A CGG, como se pode notar, possui atualmente um papel de coadjuvante na vigilância das zonas marítimas ou na luta efetiva contra a pirataria. Todavia, apesar do fraco desempenho militar, a CGG tem a preocupação de alcançar todos os meios necessários para a atuação como um CRS. A Comissão procura constantemente propor soluções regionais no campo securitário, apesar de suas dificuldades (falta de recursos financeiros, problemas internos ligados à pobreza, saúde e educação e competitividade entre Estados). Ainda a despeito de sua fragilidade, a CGG busca firmar seu engajamento em uma proposta securitária, conectando entre si países contíguos com saídas para o mar.

A língua francesa dá coesão entre a maioria dos Estados e favorece a criação de um SubCRS condizente à tipologia de CRS padrão de Buzan et al. (2003), mesmo tendo a Nigéria como sendo a maior potência da região. As percepções intersubjetivas ligadas à insegurança marítima, notadamente a pirataria, são compartilhadas entre as unidades e a preocupação máxima é: criar mecanismos de segurança e defesa e securitizar os crimes marítimos na região.

Há, portanto, uma mudança evidente na forma como a CGG passou a selecionar suas prioridades e na maneira como tem lidado com o problema de insegurança marítima - que se tornou nos últimos anos a questão principal compartilhada pelos países vizinhos do Golfo. A CGG passou a cumprir uma agenda de missões ligadas à segurança, deixando praticamente para segundo plano as suas preocupações relacionadas à integração econômica. O que também nos fez inferir que, de uma comunidade econômica, a CGG estaria se transformando em um Subcomplexo Regional de Segurança.

Todavia, sem meios próprios (tecnologia e know-how) para conter a insegurança nas suas águas territoriais, com baixa capacidade de exercer coerção sob os crimes marítimos e assumir efetivamente a posição de um ator securitizador, a CGG tem outorgado a atores externos o direito de interferir na construção de sua estratégia política de segurança regional. Três desses atores citados aqui são clientes do petróleo bruto da região e também membros permanentes do CSNU: Estados Unidos, Reino Unido e França.

Conjectura-se que, a curto prazo, tal manobra da CGG poderá até resultar na diminuição dos atentados às embarcações comerciais privadas - como aconteceu no largo da Somália, em 2008, após a "Operação Atalanta”. No entanto, dificilmente colocará um fim à pirataria no Golfo da Guiné, dado as 
peculiaridades do fenômeno na região marítima estudada. Além disso, há a possibilidade desta manobra vir a condicionar a estratégia da CGG, CEDEAO e CEEAC baseada em instrumentos próprios africanos, minimizando os seus papeis como atores regionais na construção de uma arquitetura de segurança regional.

Entretanto, a participação ativa de atores externos - principalmente os do Ocidente - em assuntos de segurança (nacional e regional) e no ato securitizador da pirataria no Golfo da Guiné já é um fato. Entre outros atores e iniciativas internacionais inseridos na luta contra a pirataria e que não foram mencionados até então, citamos os especialistas em segurança marítima G8++ dos Amigos do Golfo de Guiné; a iniciativa Atlântica; a União Europeia (com apoio financeiro, logístico e de formação de agentes militares) e, o programa Evidence Exploitation Intelligence (EVEXI) da Organização Internacional da Policia Criminal (INTERPOL) que fornece apoio na exploração das informações relativas à pirataria (Ukeje e Mvomo Ela, 2013).

Em suma, países como Estados Unidos ${ }^{21}$, França, Reino Unido, Brasil e China (para citar somente os mais presentes) estão envolvidos de forma direta na luta contra a pirataria no espaço marítimo e de jurisdição dos Estados do Golfo da Guiné e oferecem seu apoio financeiro em questões logísticas de know-how ou em intervenções militares. Vale reiterar o papel da França e sua interferência como ator internacional que modela a dinâmica de segurança interna das organizações regionais. Na África do Oeste a França atua, por exemplo, na formação de exércitos nacionais, na discussão sobre a paz e a segurança no continente africano e lidera congressos sobre o assunto ${ }^{22}$.

A multiplicação de acordos, de cooperação bilateral e multilateral, a proliferação de instituições interferindo no assunto de segurança leva à consolidação do processo de securitização da pirataria no Golfo de Guiné, compartilhado entre atores regionais e internacionais. Essa interferência em assuntos de segurança regional é analisada por Ukeje e Mvomo Ela (2013) que sinalizou o risco de "extraversão" 23 da política de segurança regional. Ou seja, a

\footnotetext{
${ }^{21}$ Nos últimos cinco anos, os Estados Unidos teriam gasto mais de 35 milhões em logística, formação e equipamento de forças navais estrangeiras.

${ }^{22}$ Para mais informações, consultar: http://www.elysee.fr/declarations/article/la-declaration-finaledu-sommet-de-1-elysee-pour-la-paix-et-la-securite-en-afrique/Acesso em: 24/07/2014

${ }^{23}$ Expressão proposta por Ukeje e Mvomo Ela. Consultar: http://library.fes.de/pdffiles/bueros/nigeria/10647.pdf.
} 
perda das características securitárias e identitárias traçadas no âmbito do último encontro de cúpula da CGG.

É necessário deixar claro que, ao analisarmos esta questão de insegurança marítima, não podemos cair na armadilha de comparar a luta contra a pirataria no Golfo de Áden e a luta contra a pirataria no Golfo da Guiné. Menciona-se apenas a existência de "Estados democráticos" (ao contrário do alegado para o caso da Somália) e de instituições regionais como CGG, CEDEAO e CEEAC. O que, aliás, fez com que a Comunidade Internacional apoiasse o conjunto de atores regionais que, de certo modo, deveriam assumir sua parte de responsabilidade na luta contra o fenômeno de pirataria marítima na região.

A atuação de atores internacionais na luta contra pirataria, no entanto, é preponderante e se concretiza com uma presença militar; imposição de normas securitizadoras; pressões constantes através de discursos de porta-vozes; pela tomada de decisões e de um know-how estrangeiro na formação, por exemplo, de guardas armadas. Essa presença imutável de atores políticos estrangeiros poderá ainda provocar a perda de soberania dos países; incentivar a competição entre presidentes da região para a liderança e questões conflituosas entre alguns países do Golfo relativas às fronteiras comuns; e tornar a questão de segurança na região um problema internacional, em vez de um problema regional. Por isto, consideramos que assistimos a um processo de extraversão dos mecanismos de segurança regional e de resolução de problemas, com a interferência explícita e constante dos atores internacionais na produção de normas securitizadoras que, por vezes, questionam a soberania dos Estados do Golfo de Guiné.

A CGG, em suma, pode ser caracterizada como um SubComplexo Regional de Segurança em emergência, repleto de conflitos internos/intraestaduais e marcada por uma densidade de interações com atores externos. Entretanto, ocupa o lugar de "ator funcional" no movimento securitizador da pirataria na região marítima. Isto é, o lugar de uma "mera" audiência a ser convencida por exercer soberania plena sob o espaço onde o fenômeno é securitizado.

$\mathrm{Na}$ próxima seção, apresenta-se o movimento securitizador da pirataria no Golfo da Guiné, fazendo uso de algumas noções teóricas sobre o processo de securitização estudada no início deste primeiro capítulo. Busca-se mostrar a relevância de algumas práticas no estabelecimento do movimento securitizador em torno da pirataria na região analisada. Notadamente os atos de fala (discursos) 
e o compartilhamento das percepções intersubjetivas sobre a pirataria entre um conjunto de atores (regionais e extrarregionais).

\section{3}

\section{O movimento securitizador da pirataria no Golfo da Guiné}

É notável a existência de um movimento securitizador em torno da pirataria na região do Golfo da Guiné, envolvendo uma variedade de atores. Entre eles, temos: instituições internacionais, atores políticos individuais (países, líderes políticos), multinacionais, comunidades econômicas regionais, Complexos e SubComplexo Regional de Segurança, etc.

Para ilustrar como, na prática, se deu este início do processo de securitização, apresentamos a definição de Koungon, que esclarece o seguinte: "La sécuritisation est la construction pragmatico-linguistique qui transforme um sujet donné, à priori sans ou d'un enjeu limité, en question de sécurité" (Koungon, 2014, p.3). A partir desta, a pirataria no Golfo da Guiné pode ser entendida como uma ameaça existencial socialmente construída. Dado que há uma recente construção pragmática e linguística deste fenômeno - inicialmente pouco expressivo para a questão da segurança marítima e energética na região estudada visando destacá-lo como um tema prioritário para segurança regional e uma ameaça a ser securitizada.

As percepções compartilhadas sobre a insegurança marítima e os atos de fala são instrumentos significativos nesse processo de construção linguística. Inclui-se aqui os artigos publicados pela mídia internacional e os relatos, com depoimentos de tripulantes que foram vítimas de piratas, contribuindo para criar uma visão peculiar dos mesmos e da violência na região ${ }^{24}$. Com base nesses relatos, os elementos constitutivos da imagem construída sobre pirataria são: ameaça constante, perigosa e difícil de controlar. Seus atores são: criminosos, rebeldes, terroristas, homens de negócio, pobres desesperados e armados (...).

Faz-se necessário esclarecer que não ignoramos a pirataria ativa no Golfo da Guiné, afirmamos, ao contrário, sua existência. Tão pouco se teve a intenção de minimizar situações dramáticas vividas por indivíduos vítimas de tais atos.

\footnotetext{
${ }^{24}$ Existem inúmeros depoimentos, matérias em jornais e filmes. Podemos citar aqui o filme "Captain Philips" (2013, dirigido por Paul Greengrass) que retrata a atuação dos piratas somalis, baseado em fatos reais.
} 
Buscou-se deslindar a permanência de uma representação do fenômeno criada por atores políticos que impõem uma perspectiva subjetiva sobre os atos piratas e, baseados em interesses específicos, determinam de que forma a questão deva ser tratada.

É importante perceber, por exemplo, que os atores que constroem a imagem dos piratas são os que possuem maiores interesses econômicos na região: as multinacionais que operam na exploração do petróleo offshore, os donos de embarcações comerciais e petrolíferas e diversos países compradores do petróleo local. Ou aqueles que, enfim, têm legitimidade suficiente para definir prioridades na agenda de segurança marítima: as instituições internacionais como o Bureau Marítimo Internacional (BMI), a Organização Marítima internacional (OMI), a Câmara Comércio Internacional (CCI) e o Conselho de Segurança das Nações Unidas (CSNU).

A pirataria no Golfo da Guiné, por conseguinte, é primeiramente definida como ameaça existencial a partir dos discursos de atores políticos extra territoriais. Atores que exercem influência na mídia e opinião pública internacional têm grandes capacidades de apresentar os objetos de referência ${ }^{25} \mathrm{e}$ determinar prioridades na agenda de segurança internacional.

Essencialmente a partir dos discursos destes atores, a pirataria foi aceita como "uma ameaça existencial" e se inscreve atualmente num dos momentos mais delicados da prática de securitização - a transição do movimento para o ato securitizador. Pelo fato deste processo estar associado à questão da despolitização, a opinião das populações locais (incluímos aqui a opinião dos próprios piratas), bem como as ameaças existenciais ligadas à segurança objetiva local (citamos aqui a questão da poluição dos mares com a exploração de petróleo e suas consequências para as populações ribeirinhas e piscatórias) passaram a ser definitivamente ignoradas, corroborando o que foi defendido pelos autores da Escola de Copenhague sobre a forma como uma ameaça é construída socialmente e depois despolitizada no decorrer do processo de securitização.

Atualmente, a preocupação em erradicar os atos piratas em termos militares ganhou tal abrangência que praticamente não se cogita a possibilidade

\footnotetext{
${ }^{25}$ Objeto de referência ("referent object"), conforme os autores da Escola de Copenhagen, é algo existencialmente ameaçado em que há uma reivindicação pela sua "sobrevivência" (Buzanet al. 1998, 36).
} 
das causas e vazões para a pirataria na região marítima estarem em outros setores, como o econômico, o social, o político e o ambiental. Se tratando, portanto, de uma ameaça militar a ser dissipada com meios militares.

Nesta "política de pânico", entretanto, não só há uma acentuada predominância do setor militar, como também, há um gradual descaso com outras preocupações atuais importantes. Como exemplo cita-se: a imigração clandestina, os conflitos interestaduais e intraestaduais, o tráfico de drogas, a prática de Pesca Ilegal, não Reportada e não Regulada (pesca INN) ${ }^{26}$ cometida por atores extrarregionais e que resulta em consequências desastrosas para as populações locais.

Todo este imbróglio na atual conjuntura política do Golfo da Guiné nos sugere então que a securitização da pirataria corresponde a uma prática de "segurança subjetiva". Visto que os ataques piratas se tornaram um assunto de segurança prioritária a partir de interesses político-econômicos em jogo, e não por representar um problema social e inerente aos Estados ou, ainda, um problema de segurança de fato.

Para os principais atores envolvidos no movimento securitizador da pirataria no Golfo da Guiné - China, Reino Unido, Holanda, França, Estados Unidos, Brasil, etc. - a estabilidade no fornecimento do petróleo africano é importante. Pois, os países africanos do golfo exportam praticamente todo o produto bruto extraído e têm o melhor mercado petrolífero, depois do mercado do Golfo Pérsico. Para as companhias de exploração de petróleo (empresas privadas e multinacionais) estabelecidas na região, especialmente as localizadas na região do Delta do Níger, a segurança marítima é a condição para garantir a segurança energética local. Se encontram em uma situação de risco por serem os principais alvos dos ataques piratas - roubos, saques de petróleo, sequestros a pessoas e embarcações e, por vezes, destruição e perda completa de suas instalações - e suas demandas precisam ser priorizadas.

Por seu turno, as Instituições Internacionais - CSNU, BMI, OMI - tentam mediar a situação, fomentando parcerias militares entre atores regionais e extrarregionais, fornecendo dados sobre os movimentos e ataques piratas e

\footnotetext{
${ }^{26}$ Illegal Unreported Unregulated (IUU) Fishing in West Africa (Nigeria\&Ghana), by Professor A. Eyiwunmi Falayeffs Department of Wildlife \& Fisheries Management University of Ibadan, Ibadan Nigeria Report of a study prepared for MRAG. Para mais informações, consultar: http://www.mrag.co.uk/Documents/IUU_WestAfrica.pdf. Acesso em: 03/02/2014
} 
apresentando sugestões para estratégias de defesa e segurança de embarcações e plataformas petrolíferas. O CSNU, por exemplo, vem tendo um papel preponderante no fomento da cooperação entre os países do Golfo e as indústrias navais estrangeiras. Afirmou o seu compromisso com a securitização da pirataria no Golfo da Guiné com as duas Resoluções supracitadas, instrumentos pelos quais oficialmente expressou a sua preocupação com o fenômeno, entre outros crimes, considerando-o uma ameaça existencial para as embarcações internacionais, para a segurança marítima e desenvolvimento regional.

$\mathrm{Na}$ Res. 2018 (2011), o Conselho preconizou a importância de uma estratégia regional integrada (entre a CEDEAO, CEEAC e CGG) para erradicar a pirataria. Em novembro de 2011, três meses após essa primeira resolução e respondendo aos pedidos de assistência de alguns países da região, o CSNU organizou e financiou uma missão de avaliação da pirataria no Golfo de Guiné ${ }^{27}$. Uma das consequências da publicação do relato da missão foi a adoção de uma nova resolução: a Res. 2039 (de 2012) que promovia, com o apoio das Nações Unidas, o desenvolvimento de "um plano de estratégia regional" e a harmonização das ações dos atores regionais no mar.

O CSNU pode ser considerado, ao mesmo tempo, uma audiência a ser convencida por meio de discursos e um ator que profere discursos e se dirige a uma variedade de atores, como chefes de Estados e membros de organizações regionais, com o intuito de promover o ato securitizador da pirataria na região do Golfo da Guiné. Pelo fato de praticamente todos os membros permanentes do Conselho (Reino Unido, França, Estados Unidos e China) estarem envolvidos no movimento securitizador da pirataria no Golfo da Guiné, sua atuação tende a ser um tanto duvidosa.

Inicialmente, o CSNU foi a audiência solicitada por Yayi Boni (presidente da república do Benim) com apoio da França e dos Estados Unidos (Ukeje e Mvomo Ela, n.d, p.28). O CSNU tomou posição a favor da luta contra a pirataria e roubos à mão armada cometidos nos mares dos países do Golfo precisamente após este episódio e, logo em seguida, publicou as Res. 2018 e a Res. 2039.

Duas outras instituições internacionais trabalham lado a lado com o CSNU e, de certa forma, também contribuíram para as tomadas de decisões no curso do

\footnotetext{
${ }^{27}$ Relatório da missão de avaliação das Nações Unidas sobre a pirataria no Golfo de Guiné (07 a $24 / 11 / 2011)$.
} 
movimento securitizador da pirataria no Golfo da Guiné: o BMI e a OMI. Suas atuações estão voltadas tanto para o fomento de implementação de estratégias de segurança marítima, quanto para o fornecimento de dados e estatísticas por meio de relatórios .

A respeito das informações publicadas sobre pirataria no Golfo da Guiné, Pérouse Montclos (2011, p. 2) mostrou alguns limites e explicou como a metodologia utilizada pelo BMI, por exemplo, apresenta falhas. O autor comenta o fato do Bureau se limitar a dar estatísticas a partir do registro de ataques sofridos por navios estrangeiros, sabendo que muitos ataques não são declarados devido a questões financeiras ligadas às taxas e custos dos seguros privados. A BMI, por conseguinte, manipula as informações sobre a pirataria em função de determinados interesses.

Outro aspecto metodológico levantado por Pérouse (Idem) é que a noção de "ataque" é muito vaga. O autor destaca ainda a subjetividade do BMI, que como porta-voz da indústria marítima, denuncia os atos piratas e qualquer outro ato criminoso nos mares e defende seus clientes. Cabe destacar que o Bureau é também membro consultivo na Assembleia Geral da Organização Marítima Internacional (OMI), o que o leva a exercitar um papel de peso na construção da pirataria como ameaça existencial e na securitização do fenômeno com base em estatísticas que são os únicos dados processados e aceitos pelas organizações internacionais e organizações regionais de referência, como a CSNU e a CGG, respectivamente (Oliveira, 2013) ${ }^{28}$.

Diante da subjetividade e dos interesses políticos e econômicos óbvios do BMI, questiona-se o fato do Bureau emitir soluções para erradicar a pirataria da região. O BMI acusa o fraco desempenho do sistema jurídico dos Estados do Golfo de Guiné, que facilita a atuação dos piratas e aproveita dos discursos e de sua autoridade e reconhecimento internacional para pressionar esses Estados, bem como atores internacionais e imprensa, a considerar a pirataria na região como “ofensa grave” ao Direito Internacional do Mar.

A OMI, por sua vez, mais recentemente apoiou a criação do West and Central Africa Maritime Security Trust Fund, que levou à adoção do "código de conduta" para a prevenção dos crimes marítimos, mencionado anteriormente. A

\footnotetext{
${ }^{28}$ Para mais informações, consultar o site: http://www.scielo.gpeari.mctes.pt/scielo.php?pid=S1645-91992013000400003\&script=sci_arttext
} 
iniciativa do Código de Conduta de Repressão da pirataria, roubo à mão armada contra navios e atividade marítima ilegal no Golfo da Guiné, assinado em junho de 2013, respondia diretamente às preocupações da Comunidade Internacional e do CSNU e visava a "adoção de um acordo multilateral limitador" com "objetivo de erradicar as atividades ilícitas nas costas da África do oeste e central"29. Vinte e dois países da região do Golfo da Guiné assinaram este código que foi ainda ratificado pela CEDEAO, a CEEAC e a CGG num dos encontros mais solenes entre atores políticos regionais e atores políticos internacionais.

A seguir, apresenta-se algumas noções jurídicas que corroboram o fato da pirataria no Golfo da Guiné ser uma ameaça existencial socialmente construída e que fornecem uma dimensão mais precisa sobre o quão este fenômeno se encontra inserido na esfera de "política de pânico". A atuação das Companhias de Segurança Marítima Privada (CSMP) será ilustrada com o objetivo de fornecer mais dados sobre a implementação do ato securitizador da pirataria no Golfo da Guiné.

\section{4}

\section{Aspectos jurídicos sobre a pirataria e segurança marítima no Golfo da Guiné}

É importante saber que, em termos jurídicos, a maioria dos crimes de ordem marítima e econômica no Golfo da Guiné não configuram o crime internacional de pirataria. Pois, conforme dispõe o artigo que conceitua esta prática - $101^{\circ}$ da Convenção das Nações Unidas sobre o Direito do Mar $(\mathrm{CNUDM})^{30}$, configura-se como pirataria atos criminosos praticados em alto mar $^{31}$ ou fora do espaço de jurisdição de um Estado costeiro. A figura 2 ilustra os limites marítimos de um Estado costeiro e suas respectivas distâncias.

\footnotetext{
29 Informação disponível em: http://gabonreview.com/blog/les-decisions-du-sommet-sur-lapiraterie-maritime-de-yaounde/. Acesso em: 20 de janeiro de 2015.

30 A CNUDM de Montego Bay (1982), UNCLOS na sigla em Inglês, é a norma costumeira do Direito Internacional do Mar. Foi ratificada pela maioria dos países da comunidade internacional em 1988 e está em vigor desde 16 de novembro de 1994. Para acessar a Convenção na íntegra ver o link abaixo: http://www.un.org/depts/los/convention_agreements/texts/unclos/unclos_e.pdf

${ }^{31} \mathrm{O}$ alto mar é o espaço marítimo que se inicia depois da zona econômica exclusiva (ZEE) do Estado costeiro, incluindo as águas sobrejacentes à plataforma continental (PC).
} 


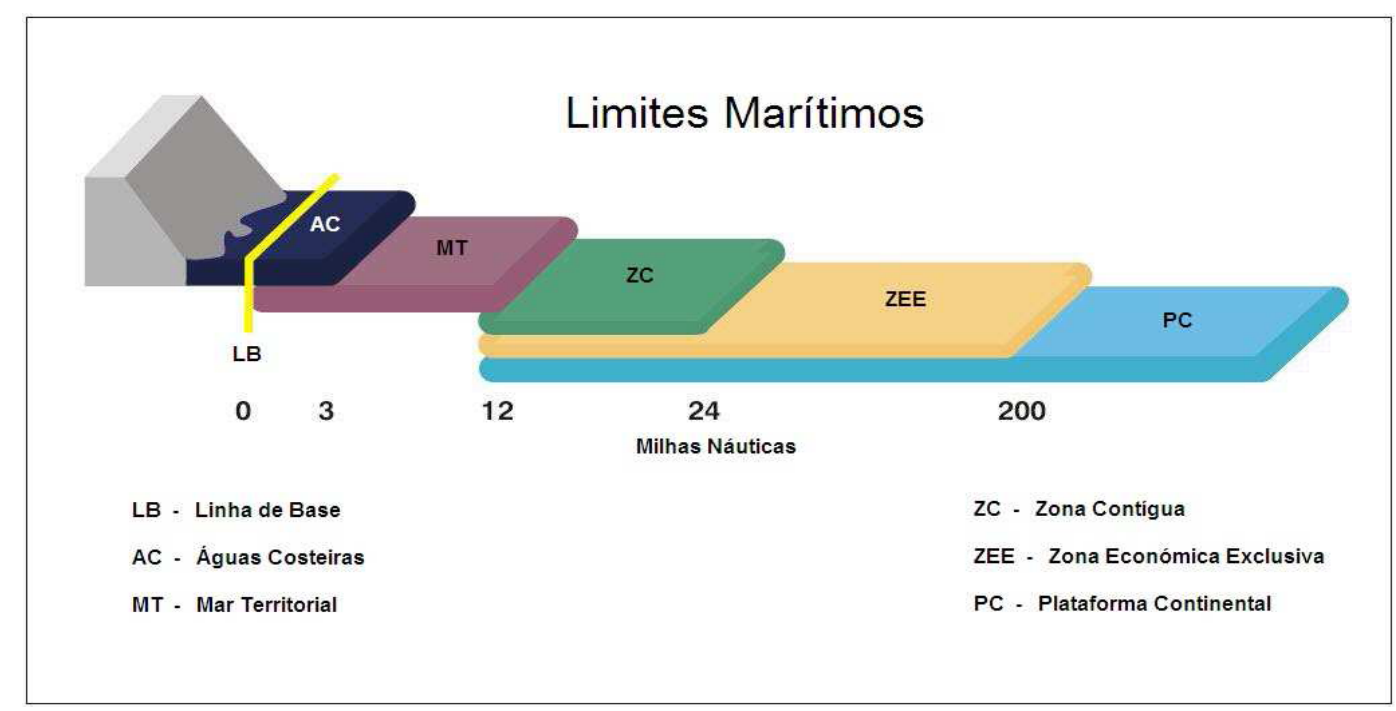

Figura 2: Limites Marítimos

Fonte: Disponível em: $<$ http://www.isegi.unl.pt/unigis/Dissertacoes.asp $>$. Acesso em: 03/03/2010.

A pirataria, em concorde com o disposto no artigo $101^{\circ}$ da Convenção supracitada, é ${ }^{32}$ :

a) Todo o ato ilícito de violência ou de detenção ou todo o ato de depredação cometidos, para fins privados, pela tripulação ou pelos passageiros de um navio ou de uma aeronave privados, e dirigidos contra:

i) Um navio ou uma aeronave em alto mar ou pessoas ou bens a bordo dos mesmos;

ii) Um navio ou uma aeronave, pessoas ou bens em lugar não submetido à jurisdição de algum Estado;

b) Todo o ato de participação voluntária na utilização de um navio ou de uma aeronave, quando aquele que o pratica tenha conhecimento de fatos que deem a esse navio ou a essa aeronave o caráter de navio ou aeronave pirata;

c) Toda a ação que tenha por fim incitar ou ajudar intencionalmente a cometer um dos atos enunciados na alínea a) ou b).

No Golfo da Guiné, os ataques às embarcações comerciais privadas ocorrem essencialmente nas Zonas Econômicas Exclusivas (ZEE), nos mares territoriais (MT) e nos portos dos Estados costeiros. Não se tratando, portanto, do que se convencionou chamar de pirataria, pela CNUDM de 1982. O próprio diretor adjunto da Divisão de Segurança Marítima na OMI, Cris Trelawny, problematizando a questão de segurança marítima no Golfo da Guiné explicou: “(...) the vast majority of attacks over the past few years had occurred within the jurisdiction of coastal states and therefore were not piracy per $s e^{33}$. Estes crimes,

\footnotetext{
${ }^{32}$ CNUDM, tradução e grifos nossos.

${ }^{33}$ Ver a página 15 do relatóro da conferência sobre segurança marítima no Golfo da Guiné organizada a 6 de dezembro de 2012 pela Coventry University e a Chatham House de Londres:
} 
segundo Trelawny (idem) e conforme o entendimento jurídico, são classificados como roubos ou assaltos à mão armada. Crimes regidos pelos códigos de processos penais de todos os Estados da costa africana.

A diferenciação dos tipos de crime tem implicações significativas no tratamento e prevenção dos mesmos. A pirataria é designada como crime internacional pela CNUDM e todos os Estados, inclusive as que não ratificaram a Convenção de 1982, tem a obrigação de "cooperar com todos os meios possíveis" para erradicá-la "no alto mar ou em qualquer outro lugar fora da jurisdição de qualquer Estado"34. No alto mar particularmente, por ser considerado pela CNUDM como res comunis ("patrimônio comum da humanidade"), todos os Estados têm a prerrogativa de poder fazer cumprir as leis internacionais e, portanto, de erradicar a pirataria. Por seu turno, os roubos ou assaltos à mão armada no espaço de jurisdição de um estado costeiro são de responsabilidade única do Estado. Ao menos que exista uma autorização do Estado costeiro, a perseguição a uma suposta embarcação pirata por parte de uma embarcação militar de outro Estado e/ou qualquer embarcação militar internacional dentro do seu espaço de jurisdição, por exemplo, é extrajurídica e improcedente, pois fere os princípios da CNUDM de Montego Bay.

Neste sentido, a situação no Golfo da Guiné se apresenta como sendo bem diferente das situações anteriores em que o CSNU se propôs a combater a pirataria. Como exemplo, cita-se o Golfo de Áden (largo da Somália), onde o Conselho permitiu a intervenção de forças militares internacionais para erradicar o crime através das resoluções 1814 (2008);1816 (2008); 1838 (2008); 1844 (2008); 1846 (2008); 1851 (2008) e 1897 (2009). Os ataques às embarcações privadas no largo da Somália, na maioria dos casos, eram perpetrados bem distante da sua ZEE, por vezes, até nas proximidades das costas de Moçambique e da Índia e, por isso, justificavam uma intervenção internacional na luz da CNUDM.

Já no Golfo da Guiné, embora o CSNU nas Resoluções 2018 (2011) e 2039 (2012) também tenha frisado a necessidade de uma intervenção para combater a "pirataria", entendeu-se que, em razão do disposto na CNUDM, a

\footnotetext{
$<$ http://www.chathamhouse.org/sites/files/chathamhouse/public/Research/Africa/0312confreport maritimesecurity.pdf.>Acesso em: 04/03/2014.

${ }^{34}$ Artigo $100^{\circ}$ da CNUDM de 1982.
} 
responsabilidade primária seria dos Estados costeiros ${ }^{35}$. Relegando a intervenção internacional na região, o CSNU afirmou assim o seu compromisso com a soberania e a integridade territorial dos Estados costeiros, porém, sinalizando a abertura para crimes marítimos que havia sido criada pela Convenção de $1982^{36}$.

Coube então à CSNU forjar parcerias entre os países e entre as comunidades regionais do Golfo da Guiné. Várias iniciativas, organizadas entre estes, ganharam fôlego a partir de então. Entre elas citamos: a atuação em conjunta da Força Naval Nigeriana (NN) com a Agência de Segurança e Administração Marítima Nigeriana (NIMASA); os projetos de segurança cooperativa entre as potências regionais (por exemplo, Nigéria e Benim); a articulação da CGG com a CEDEAO e a CEEAC e as várias estratégias criadas individualmente e com mecanismos próprios de cada uma das comunidades citadas.

Entretanto, devido às dificuldades encontradas pelos países e comunidades regionais em dar a resposta desejada ao CSNU e à comunidade internacional, novas formas de cooperação extrarregional começaram a ganhar amplitude, contando com a participação essencialmente dos Estados Unidos, do Reino Unido e da França no patrulhamento do local. A título de exemplo citamos quatro modelos de cooperação e parcerias recém pactuados entre atores regionais e internacionais:

- O "Exercício Militar Obangame Express" que sob o auspício da African Command (AFRICOM) dos EUA, reuniu Alemanha, Angola, Bélgica, Benim, Brasil, Camarões, Costa do Marfim, Dinamarca, Espanha, França, Gabão, Gana, Guiné Equatorial, Holanda, Itália, Nigéria, República do Congo, Portugal, São Tomé e Príncipe, Togo e Turquia ${ }^{37}$.

- As "atividades operacionais conjuntas de treinamento, desportivas e de relações entre comunidade" entre a Marinha Real (Reino Unido) e a Marinha de Gana ${ }^{38}$.

\footnotetext{
${ }^{35}$ Artigo 3 da Resolução 2039 (2012) do CSNU.

${ }^{36}$ Enfatizamos o fato de que a CNUDM de 1982 é de carater essencialmente político. Contempla a questão da soberania dos Estados - limites de fronteiras marítimas, os modos de passagem no espaços de jurisdição de um estado costeiro, o acesso exclusivo à exploração dos recursos naturais vivos e não vivos, etc. - e não questões ligadas à segurança marítima propriamente dita.

${ }^{37}$ Informações disponíveis em: http://www.emfa.pt/www/noticia-553. Acesso em: 15/04/2014.

${ }^{38}$ Informações disponíveis em: http://www.ghanaweb.com/GhanaHomePage/regional/artikel.php?ID=318002.

Acesso em 25/07/2014.
} 
- O “Centro Inter-regional de Coordenação e Segurança Marítima do Golfo da Guiné" inaugurado com o apoio da França para operar como uma "ferramenta para a securitização" dos espaços marítimos da região africana $^{39}$

- A "participação conjunta em exercícios de vigilância no Golfo da Guiné" estabelecida entre Portugal e Angola para o período referente a 2015$2017^{40}$.

Desta forma, os países estrangeiros com vínculos históricos locais e interesses estratégicos na região marítima acondicionaram a CNUDM de 1982 e, por assim dizer, criaram uma espécie de jurisprudência para securitizar/erradicar a "pirataria" no espaço de jurisdição dos Estados africanos. Passaram então a patrulhar as águas territoriais dos países do Golfo da Guiné (com a autorização outorgada pelos seus respectivos Estados costeiros) e estabeleceram um conjunto de decisões e orientações jurídicas sobre a forma de lidar, julgar e punir os "piratas".

Para se ter uma noção concreta desta "política de exceção" - pelo fato de conformarem crime internacional - atos piratas na luz da CNUDM só poderiam ser julgados no Tribunal Penal Internacional (TPI - foro de jurisdição competente). Entretanto, salvo engano, isto nunca acontece. Por acarretar elevados custos processuais, "os piratas" são julgados em "tribunais de aluguel" dos países vizinhos. E, vale frisar, jamais nos seus próprios países. Embora não seja um assunto abordado, julgar um pirata no TPI ou no seu próprio país dá voz e agência a este indivíduo como um ator político. Assim, este é julgado longe de qualquer audiência relevante que o possa escutar ou propagar o seu discurso, que, por vezes, é melindrado e se confunde com uma espécie de militância política. Aliás, o caso do nigeriano e militante do MEND, Henry Okah (citado na introdução) não é um caso isolado. Foi certamente pelas razões acima mencionadas que este foi condenado pela corte sul-africana e não pelo TPI ou pela corte jurídica do seu país.

\footnotetext{
${ }^{39}$ Informação disponível em: http://www.ambafrance-cm.org/Inauguration-du-Centre. Acesso em $12 / 09 / 2014$.

${ }^{40}$ Informação disponível em:

http://www.cargoedicoes.pt/site/Default.aspx?tabid=380\&id=10835\&area=Cargo. Acesso em 03/12/2014.
} 
É por esta razão, e pelas noções jurídicas apresentadas no início desta seção, que questiona-se aqui a securitização da pirataria no Golfo da Guiné. Quanto mais dados tem-se sobre esta prática de segurança em torno da questão da pirataria na região marítima, fica mais nítido que se trata de uma "política de exceção permanente" sendo instaurada de fato. A proliferação da atuação das CSMP apresentada a seguir remete a questões jurídicas, políticas e econômicas deveras controvérsias no Golfo da Guiné e ilustra algumas tendências desta "política de exceção".

\subsection{1}

\section{A proliferação das Companhias de Segurança Marítima Privada no Golfo da Guiné}

A questão de passagem e de circulação no espaço marítimo dos Estados costeiros do Golfo da Guiné é ainda mais problemática quando se trata das CSMPs oferecendo os seguintes serviços: escolta para as embarcações comerciais privadas; aluguel de pessoal armado para as embarcações comerciais privadas; resgates de navios e de mercadorias roubadas; recolha de informações sobre a atuação de grupos piratas; etc. Pois, até o presente momento, além desta espécie de companhia não ter respaldo jurídico/legal para atuar a nível internacional, na região marítima estudada não existe consenso sobre a circulação das CSMPs nos espaços de jurisdição dos Estados costeiros. Desta conjunção, resulta seu contínuo tráfego às margens das leis do Direito Internacional do Mar estabelecidas pela CNUDM de 1982.

É comum as CSMPs adentrarem as fronteiras marítimas de Estados costeiros armados e, em grande parte dos casos, abrirem fogo contra embarcações supostamente piratas alegando o "direito à legítima defesa". No entanto, salientase que, embora a Convenção não verse sobre as CSMPs, ela prevê uma modalidade de trânsito para todas as espécies de embarcações (militares ou privadas) no espaço de jurisdição do Estado costeiro: a "passagem inocente". Esta é uma das poucas restrições à soberania do Estado costeiro prevista pela Convenção. O "direito de passagem inocente" é concedido essencialmente para adentrar no mar territorial de um Estado, direcionar ao porto ou transitar entre fronteiras marítimas de Estados costeiros. E, como dispõe o artigo $19^{\circ}$ da CNUDM, "a passagem é inocente desde que não seja prejudicial à paz, à boa 
ordem ou à segurança do estado costeiro". Destarte, esta deixa de ser inocente quando a embarcação ameaça a soberania e a integridade territorial do Estado.

O uso da força ou o simples porte de qualquer tipo de arma no espaço de jurisdição de um Estado costeiro por parte das CSMPs, no caso concreto pode ser lido como uma ameaça à soberania e à integridade física do Estado e, se este assim o entender, pode adotar medidas sérias para punir tal conduta. Um caso curioso envolvendo uma CSMP russa e a autoridade marítima nigeriana foi relatado por Anyimadou e delineia as medidas que podem ser tomadas pelos Estados costeiros contra as companhias.

The Myre Seadiver and its crew were seized by the Nigerian navy in October 2012, accused of illegally entering Nigerian waters carrying weapons. The ship's owner insisted that the vessel had secured licenses from the Nigerian authorities to carry this weaponry, but this claim was rejected and the crew was charged with illegally possessing and importing arms and ammunition (Anyimadou, 2013, p. $11)$.

As CSMPs, ou guardas armados contratados por embarcações privadas, como se percebe, não estão autorizados a atuar nas águas territoriais dos países do Golfo da Guiné. Todavia, por esta modalidade ser extremamente recente na região, não se pode precisar se todos os países adotam as mesmas medidas em relação às companhias e se esta decisão prevalecerá por muito tempo. Como Anyimadou elucida:

\begin{abstract}
Ship-owners seeking armed presence in Nigerian, Benin or Togolese waters can pay for national armed police or military personnel to provide escort vessels or to travel on board commercial vessels. While maritime security companies are not permitted to deploy armed guards in coastal waters, privately contracted security personnel do act in the region in a non-armed capacity (Anyimadou, op. cit., p. 11).
\end{abstract}

Informações disponíveis no relatório da "Conferência sobre segurança marítima no Golfo da Guiné”,41, contudo, mostram que as CSMPs: “(...) are keen to get involved in the Gulf of Guinea following their perceived success in the Gulf of Aden, with floating armouries already preparing to deploy”.

\footnotetext{
41 Citada anteriormente. Consultar páginas 22 a http://www.chathamhouse.org/sites/files/chathamhouse/public/Research/Africa/0312confreport_m aritimesecurity.pdf
} 
Cabe lembrar que, com a "Operação Atalanta" ${ }^{42}$ no largo da Somália e a promoção de um ambiente mais seguro na região marítima, grande parte das CSMPs vêm buscando regiões marítimas capazes de garantir a sustentabilidade do setor. O Golfo da Guiné, dada a quantidade de mercados e o crescente aumento da pirataria, é atualmente uma das regiões mais propícias para o investimento em CSMPs. Além disto, o fato da região ser considerada um espaço marítimo de "alto risco para a segurança marítima" garante às companhias grandes prêmios para as suas atuações (relatório UNDOC, nota 132).

Para países como a Nigéria, uma das preocupações em relação às CSMPs está baseada no medo de diferentes tipos de navios que entram em suas águas territoriais. O que poderia rapidamente fugir do controle das autoridades, tornando-se ainda mais difícil para a marinha nacional mitigar crimes como: a venda ilegal de armamentos, a pesca não reportada e não declarada, o tráfico de drogas, etc. Esta discussão em Nigéria, no entanto, gira em torno de questões jurídicas, políticas e econômicas controvérsias.

O dispositivo marítimo que regula o Direito Internacional do Mar, como viu-se, salienta que o Estado costeiro é o único responsável legítimo para dar segurança às embarcações comerciais privadas no seu espaço de jurisdição. As autoridades marítimas nigerianas pretendem exercer sua soberania e evitar as críticas a uma suposta privatização da segurança marítima. Entretanto, como pode-se averiguar, a Nigéria não é totalmente contra as CSMPs. Inclusive, tem recebido apoio de CSMPs para robustecer a sua marinha ${ }^{43}$ :

PMSCs are already used for gathering intelligence that is then communicated to the Nigerian Navy. The Nigerian military focus is on the accumulation of hardware and personnel, but surveillance and satellite technology are crucial. This needs to be provided by the government or, if not, by the private sector.

Este assunto também passa por uma questão política e econômica conveniente para os oficiais da marinha - o recebimento de recompensas e prêmios para escoltar embarcações comerciais privadas. Muitos basicamente entendem a escolta de navios comerciais em suas águas territoriais como serviços

\footnotetext{
${ }^{42}$ Operação internacional instituída pelo CSNU para combater a pirataria na região.

${ }^{43}$ Ver a página 23 do relatório da conferência sobre segurança marítima no Golfo da Guiné organizada a 6 de dezembro de 2012 pela Coventry University e a Chatham House de Londres: http://www.chathamhouse.org/sites/files/chathamhouse/public/Research/Africa/0312confreport_m aritimesecurity.pdf
} 
que estão além de suas obrigações. No entanto, as recompensas exigidas pela marinha nigeriana são, em boa medida, maiores do que as exigidas pelas CSMPs. Isto faz com que muitos investidores prefiram negociar com as seguradoras privadas. Para frear esta disposição, a marinha nigeriana tem pressionado as CSMPs a fechar acordos para circulação e trânsito em suas águas territoriais. Anyimadou explica que, porém: "The licensing required for these companies is stringent - particularly in Nigeria, where licence acquisition takes time because of the cost and number of ministries involved" (Anyimadou, 2013, p. 11). Para resolver este impasse, a marinha nigeriana e as CSMPs se vêm obrigadas a cooperar para alcançar seus interesses pessoais. A Nigéria, com algumas restrições, libera as águas territoriais e recebe da parte das CSMPs, comissões, armamentos, transferência de tecnologias e prestações de serviços.

Com estes acordos, todavia, há uma nítida proliferação das CSMPs e a questão da violência no espaço marítimo nigeriano vem se tornando um problema cada vez mais sério. Existem, inclusive, relatos de que guardas armados foram assassinados por piratas quando acompanhavam navios comerciais nas águas territoriais nigerianas (Anyimadou, 2013, p.11). Os piratas no Golfo da Guiné, além de serem mais equipados do que os da costa da Somália, são anunciados como sendo muito mais violentos, pois não valorizam a vida das tripulações e é comum tratarem estes com muita hostilidade, explica Anyimadou (Idem). Por seu turno, como é sinalizado na citação abaixo:

The PMSCs used so far in West Africa have been ill-trained, which has led to firefights. Furthermore, effective counter-piracy operations are dependent on the use of expensive hardware, most notably helicopters. The fact that, so far, this has not been the case in the region was seen as demonstrating why the use of PMSCs, especially local ones, needs to be regarded as a last resort rather than as an effective counter-piracy mechanism ${ }^{44}$.

As medidas adequadas contra os crimes marítimos no Golfo da Guiné, por conseguinte, não precisariam passar pela utilização das CSMPs. Pois, além destas atuarem sem um respaldo legal e sem condições adequadas para garantir a segurança de embarcações comerciais no local, exacerbam a violência. Enquanto os Estados costeiros locais não garantem a segurança marítima das embarcações

\footnotetext{
${ }^{44}$ Ver a página 23 :

http://www.chathamhouse.org/sites/files/chathamhouse/public/Research/Africa/0312confreport_m aritimesecurity.pdf
} 
comerciais privadas, algumas recomendações - tais como a colocação de arame farpado em navios e a utilização de defesas não-letais e mecanismos antiembarque - tem sido apresentadas pelo BMI e a OMI (Idem).

Ao longo deste capítulo, baseando-se essencialmente nas teorias desenvolvidas pelos autores da Escola de Copenhague (TCRS) e na CNUDM, procurou-se mostrar a existência de um movimento securitizador da pirataria no Golfo de Guiné. Apresentamos os elementos acerca de como a pirataria se tornou uma ameaça compartilhada de forma intersubjetiva entre vários atores, resultando em um movimento político-militar internacional para erradicá-la.

Procurou-se ainda apontar para o fato de que a pirataria no Golfo da Guiné não é discutida na esfera da política normal e sim, no âmbito da política de pânico e de exceção. O espectro militar da securitização da pirataria no Golfo da Guiné também foi sinalizado, mostrando a predominância da ideia de que a pirataria é uma ameaça existencial que deve ser ajuizada somente no setor militar.

Ainda dentro da noção de "política de exceção", procurou-se mostrar que, de acordo com a CNUDM de 1982, os crimes marítimos no Golfo da Guiné, de forma geral, sequer configuram crimes de pirataria. São crimes que ocorrem nas ZEE dos Estados costeiros e, portanto, a responsabilidade primária em tratar destes crimes é dos mesmos Estados. Finalmente, julgou-se interessante trazer a questão da proliferação das CSMPs para mostrar os desdobramentos incontroláveis que podem ser provocados por uma luta desenfreada contra a pirataria marítima.

No próximo capítulo propõe-se repensar a pirataria no Golfo da Guiné e problematizar a ideia de marginalização - em geral associada a sujeitos localizados fora do centro de poder. Como perceberemos, os crimes marítimos denominados como pirataria na região estudada também envolvem a participação de movimentos políticos e sociais locais (não estatais) e, por vezes, redes mais amplas ligadas aos Estados e, não apenas indivíduos à margem da história. 


\section{3. \\ REPENSANDO A PIRATARIA NO GOLFO DA GUINÉ}

É comum nos depararmos com a imagem depreciativa dos piratas, construída no imaginário popular em diferentes lugares ${ }^{45}$ do mundo a partir da literatura e de outras linguagens, como o cinema e a mídia, que mais recentemente muito contribuíram para a sua conotação.

No âmbito das Relações Internacionais (R.I.) e nos relatórios de instituições como BMI, OMI e Chatham House, também é comum encontrar definições fixas sobre pirataria, baseadas na identificação de fatores e causas que explicam as ocorrências apresentadas nas suas tipologias (Gosh, 2013, p.13; Samiotis et al., 2013, p.2). Murphy (2010, p.9), por exemplo, identifica quatro condições que explicam a existência da pirataria moderna: 1) uma topografia favorável; 2) a prevalência de espaços não governados; 3 ) a existência de fraca aplicação da lei ou quase nenhuma vontade política dos governos (ambiente cultural e político não hostil à pirataria) em acabar com os ataques piratas; 4) a possibilidade de arrecadar valores financeiros consideráveis em comparação aos riscos mínimos corridos. Como averiguaremos mais adiante, a questão dos "Estados fracos" e a ideia de "espaços não governados ou mal governados", tem sido recorrente na análise de especialistas em R.I.

Partindo desses pontos apresentados, escolheu-se trabalhar com alguns autores, principalmente cientistas sociais, que procuram fugir do lugar-comum sobre a pirataria e buscam romper com a imagem fixa negativa e superficial dos piratas. Estes pesquisadores, ao nosso entender, propõem teorias que problematizam o quadro e auxiliam o entendimento acerca da complexidade e heterogeneidade da pirataria e seu dinamismo. Não tratamos de maneira exaustiva os autores que trabalham sobre o assunto. O objetivo foi entender os atos piratas a partir de diferentes perspectivas. Com a leitura dos textos de Hobsbawm (1976), Dawdy (2011) e Dawdy \& Bonni (2012), por exemplo, percebeu-se a importância das especificidades do fenômeno num período dado e na região onde ocorre (Thomson, 1994).

\footnotetext{
${ }^{45}$ Análises realizadas no âmbito da cultura popular anglófila mostram que os piratas são desenhados no imaginário social como predadores, parasitas, criminosos, bandidos, rebeldes, heróis, heroínas, malfeitores, oportunistas, ladrões armados, invasores, saqueadores, ladinos e assassinos sanguinários...etc. (ver PENELL 2001, BABITS et al. 2006, HOBSBAWM, 1976).
} 
Hobsbawm, historiador de renome, tem o mérito de ter iniciado uma pesquisa assaz original para sua época. Nos anos setenta, o historiador procedeu a uma análise do banditismo de forma geral, entendendo-o como uma forma "primitiva" de protesto social. Os argumentos construídos pelo historiador são válidos, não obstante, há discordâncias com relação a ideia de forma primitiva de protesto social.

Hobsbawm (1976) analisou a atuação de diversos grupos sociais, entre outros, piratas, corsários e bandidos em diferentes épocas e regiões do mundo. A perspectiva de trabalho adotada pelo historiador britânico foi a de contar a história desses homens ${ }^{46}$, tentando se aproximar de sua realidade. Utilizou-se de relatos de piratas e corsários e músicas populares (dentre outros recursos) para entender o contexto do banditismo e seu funcionamento. Para Hobsbawm, não existe um tipo apenas de bandido e nem todos os bandidos podem ser considerados inimigos do Estado. O autor entende que os conflitos de classe - ou seja, uma situação econômica de desigualdade - podem gerar bandidos e considera que o banditismo - no qual inclui a pirataria - é um fenômeno universal que visa, muitas vezes restaurar a ordem "das coisas tradicionais" (Hobsbawm, 1976, p.12).

Cabe frisar que, em sua obra, o autor trata do banditismo social que ocorre em espaço terrestre, manifestando-se de formas diversas: protestos e rebeliões camponesas, por exemplo. $\mathrm{O}$ autor considera ainda que os bandidos sejam um grupo social mobilizado por um sentimento de justiça e que defendem os mais fracos. A luta por justiça é, portanto, o leitmotiv dos bandidos/piratas, sendo considerados pelo historiador - assumidamente marxista - como revolucionários e distintos dos ladrões comuns. O autor se debruça sobre a temática e procura entender quem são os bandidos; como eles atuam e porquê; como criam redes econômicas e sociais próprias e estabelecem relações políticas com intermediários que facilitam sua conexão com redes maiores de comércio (Hobsbawm, op. cit., p.20).

A metodologia proposta por Hobsbawm, no entanto, poderia ser aplicada ao caso da pirataria nos mares e, salvo engano, não tivemos acesso a nenhuma pesquisa desse gênero na área das R.I. ou ciências sociais. Outro elemento de

\footnotetext{
${ }^{46} \mathrm{~A}$ partir das nossas leituras, constatamos que os pesquisadores definem a história dos piratas como história de homens. No seu livro, Hobsbawm menciona Maria Bonita, mas, o caso da companheira do Lampião parece ser uma exceção.
} 
análise relevante proposto pelo autor é o conceito de marginalização. O historiador define que os homens (bandidos/piratas) se encontram à margem da ordem estabelecida e é essa marginalização que os leva a querer conquistar sua liberdade, mas também seu espaço dentro da sociedade. Embora Hobsbawm reconheça que Robin Hood é apenas um mito, a figura do herói e justiceiro permeia sua análise. Apesar de a análise ser imbuída de certo conteúdo ideológico, o historiador contribuiu para mostrar que o banditismo social incluímos aqui a pirataria marítima - pode ser entendido a partir de uma perspectiva política de luta contra a insatisfação local.

Os historiadores Samatar, Lindberg e Mahayni (2010, p.11) igualmente alinhados na perspectiva marxista, recuperaram a ideia de luta pela justiça ao apresentar os piratas como atores que lidam com situações de extrema desigualdade, pobreza e desemprego, confrontados a situações de tensão entre classes ricas, elites e classes pobres. Os $\operatorname{roubos}^{47}$ dos Estados locais e das empresas multinacionais criam condições de vida insuportáveis para as populações locais, obrigando-as a procurar formas de resistir a qualquer custo a tal situação. Os autores citados defendem a teoria da "predação-resistência", que permite desconstruir a noção totalizante e vaga do pirata, atentando para as motivações específicas e variadas dos indivíduos ou grupos organizados ao cometerem atos piratas.

Por sua vez, Dawdy (2010), numa vertente mais etnográfica, visa a se aproximar do ponto de vista dos denominados piratas ao realizar entrevistas ou lendo biografias de piratas. Essa abordagem nos permite descobrir os discursos dos atuantes que não possuem legitimidade internacional. Através das histórias marítimas regionais, Dawdy e Bonni (2012, p. 674-677) constataram que as costas da Indonésia, chinesas orientais, do Caribe, da América do Sul, a costa da Somália e águas nigerianas são frequentemente consideradas como as regiões mais vulneráveis aos ataques piratas por se encontrarem em rotas de grande circulação.

\footnotetext{
${ }^{47}$ Acusar os Estados locais e empresas multinacionais de roubos e outros crimes como a poluição do meio ambiente, exploração das populações locais etc... é uma perspectiva menos explorada pelos analistas, mas que vem ganhando terreno. No caso do Golfo da Guiné, podemos citar o caso do escritor e militante Ken Saro-Wiwa que promoveu, nos anos noventa, diversas campanhas pacíficas de denúncia das atividades da Shell em Ogoniland, no Delta do Níger. Atualmente, diversas instituições e ONGs trabalham em campanhas de denúncia. Ver por exemplo Amnesty Internacionale $<$ http://priceofoil.org/2012/05/09/shell-in-nigeria-its-worse-than$\mathrm{bad} /$ ?utm_source $=$ feedburner\&utm_medium $=$ feed\&utm_campaign $=$ Feed $\% 3 \mathrm{~A}+$ OilChange $+\% 28 \mathrm{O}$ il +Change $\% 29>$.Acesso em: 02/02/2015.
} 
Os dois cientistas consideram que a pirataria é fenômeno de constante ressurgimento. Para eles, existe uma "cultura do pirata" que é baseada no "ethos de partilha". Os piratas seriam um grupo social alternativo e marginalizado que cria e possui cultura e valores específicos. Os autores ${ }^{48}$ (op. cit. p. 678) enfatizam que a noção de pirataria está ancorada em um universo de representações e imaginário sociais - por exemplo, a imagem do "bom e mal pirata" - que nos influenciam inclusive nas análises mais teóricas do fenômeno. Dwandy e Bonni concluem que a pirataria é: “a form of morally ambiguous property seizure committed by an organized group which can include thievery, hijacking, smuggling, counterfeiting, or kidnapping." (Dwandy \& Bonni, 2012, p.675).

Muna Ali e Zahra Murad (2009) se perguntam quais são as histórias e os discursos sobre os piratas, interrogam os significados dessas histórias e observam como tais discursos são recriados na/pela mídia. Os autores não duvidam que a imagem construída e reiterada que se veicula dos piratas na Europa ou nos Estados Unidos, por exemplo, foi forjada a partir de um discurso único adotado pela mídia e esclarecem que a pirataria só pode ser compreendida se levarmos em consideração seu contexto cultural. Ali e Murad apresentam um aspecto relevante: a inscrição do pirata como agente de mudança, ator e sujeito histórico. A emergência do pirata enquanto sujeito histórico e sua atuação e participação ativa no espaço o torna uma figura pouco simpática aos olhos da mídia internacional ou mesmo local.

A seguir, apresenta-se o contexto geográfico do Golfo da Guiné e alguns elementos que permitem associar o aumento da pirataria marítima com a atual corrida pelo petróleo local. Este quadro nos proporcionará uma melhor leitura e compreensão sobre os ataques piratas no espaço marítimo estudado, bem como nas regiões de maior produção de petróleo, como é o caso do Delta do Níger.

\section{1}

\section{A pirataria e a corrida internacional pelo petróleo do Golfo de Guiné}

Em termos geográficos, a região do Golfo de Guiné corresponde à frente costeira do oceano Atlântico, entre o Senegal e Angola (conforme mostra o mapa

\footnotetext{
${ }^{48}$ Os dois analistas sobretudo questionam a representação do pirata somali como pobre, sem escolha, e que vive em um país não governado e sem autoridade legal.
} 
a seguir), sendo considerado o mais amplo de todos os golfos do continente africano. A região é dividida em duas importantes sub-regiões: por um lado o Golfo do Benin, localizado entre o Gana e o Delta do Níger (situado na Nigéria) e por outro lado o Golfo da Biafra (que começa após o Delta do Níger e vai até o Gabão).

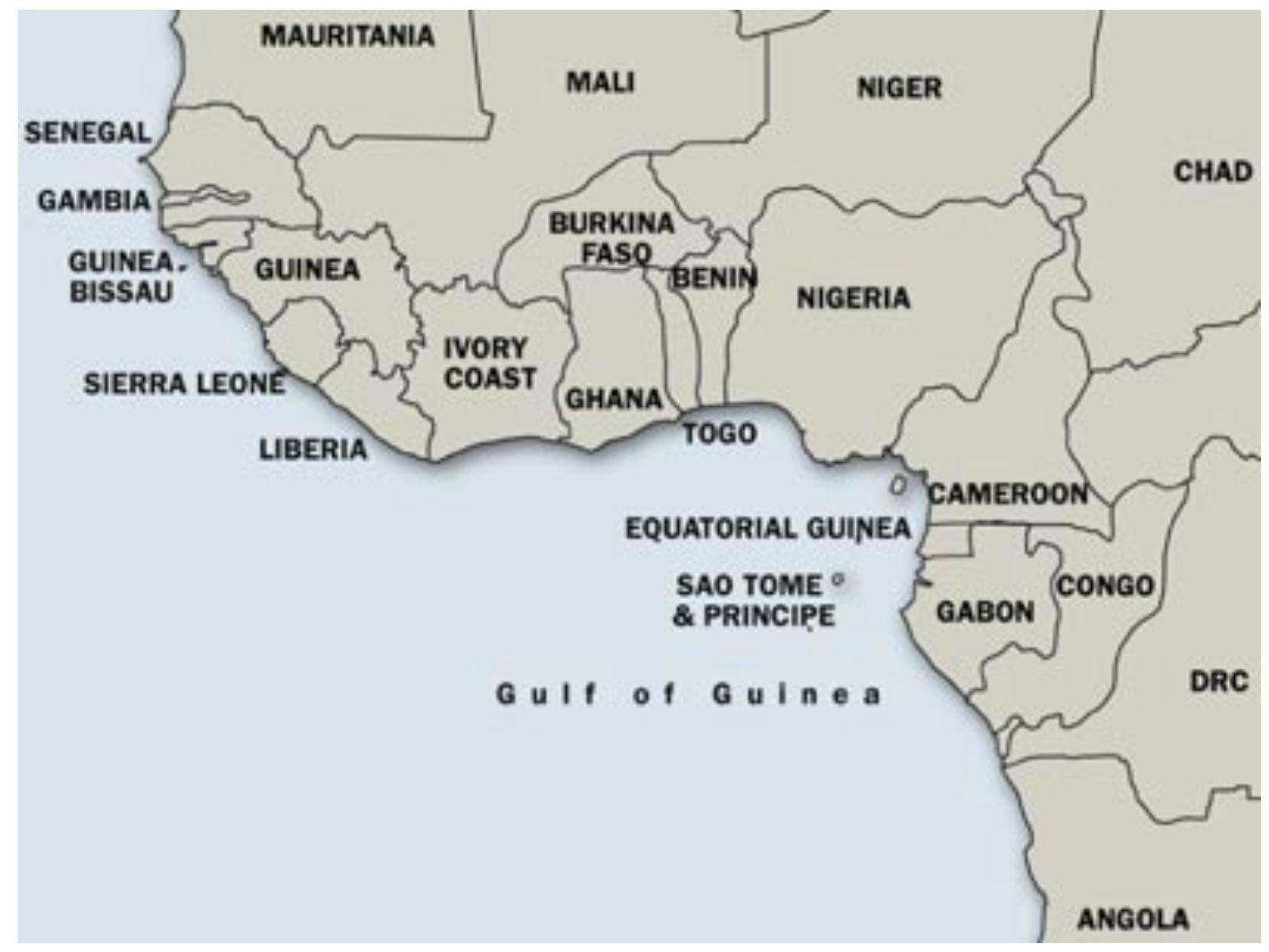

Figura 3: Mapa da região do Golfo da Guiné

Fonte: site Socialistworker. Disponível em:

$<$ http://www.socialistworker.co.uk/imageFiles/Image/2007/2078/west africa.jpg>

Pesquisadores como Watts (2012, p. 440) avaliam que o Golfo de Guiné representa uma arena limitada pela fronteira do petróleo. Isto pois, no século XX, a descoberta de jazidas de petróleo, entre outros recursos naturais, o tornou um espaço político e econômico de grande complexidade, construído em torno dos interesses dos atores e países envolvidos.

A região situa-se relativamente perto de dois continentes, cujos países são os mais interessados no petróleo bruto africano - os países da Europa e os Estados Unidos. A maior parte das jazidas são offshore, supostamente longe dos problemas das costas. Além disso, o petróleo do Golfo de Guiné é caracterizado por um baixo teor de enxofre, o que atrai muitos compradores (Escorrega, 2010). 
Sabe-se que um primeiro petroleiro saiu do Gabão em 1957, enquanto a Nigéria começava a produzir o "ouro preto" em dezembro do mesmo ano (Yates, 1996, p. 42; Frynas, Beck e Mellahi, 2000, p. 214). Desde então, a produção de petróleo cresceu sensivelmente, com grandes produtores como a Nigéria, Angola e a Guiné Equatorial. Por sua vez, os governos de Gana, Togo, Benin, Costa do Marfim, Congo-Brazzaville, Camarões e Gabão começam a investir em perfuração de plataformas continentais, gasodutos, instalações de carga e outras infraestruturas para garantir futuras produções de peso (Frynas, 2000, p.215).

Em 2010, o Wall Street Journal afirmava que "A África Ocidental ${ }^{49}$ será fonte número um de petróleo do mundo fora da Opep". Um destino que, porventura, é ao mesmo tempo a salvação e a derrocada daqueles países africanos. A salvação porque os países cujas receitas dependem exclusivamente da exploração do petróleo poderão, enfim, vir a alcançar as suas independências econômicas. E, a derrocada, pois, a corrida pelo petróleo local certamente aumentaria, trazendo novos consumidores - para além da China, a Índia, o Japão e o Brasil, cuja presença já é constante na região - e, agravando ainda mais o quadro de segurança regional e o grau de insatisfação local.

A afirmação acima, todavia, se apresenta como um axioma. As tendências apontam, de fato, para um aumento significativo de produção de petróleo no Golfo da Guiné, com a descoberta de novas jazidas de petróleo e a emergência de novos petróestados na região marítima. A seguir apresenta-se um mapa (Monié, 2012, p.5) onde constam as principais regiões e países produtores de petróleo no Golfo de Guiné, na África austral e oriental. Segundo Monié (2012, p.3), na África ocidental e central, cerca de 20 países produzirão significantes quantias de petróleo nos próximos anos.

\footnotetext{
${ }^{49} \mathrm{O}$ jornal Quotidien de l'économie (25/02/2013) afirma que o Golfo da Guiné detém 70\% da produção petrolífera do continente africano.
} 


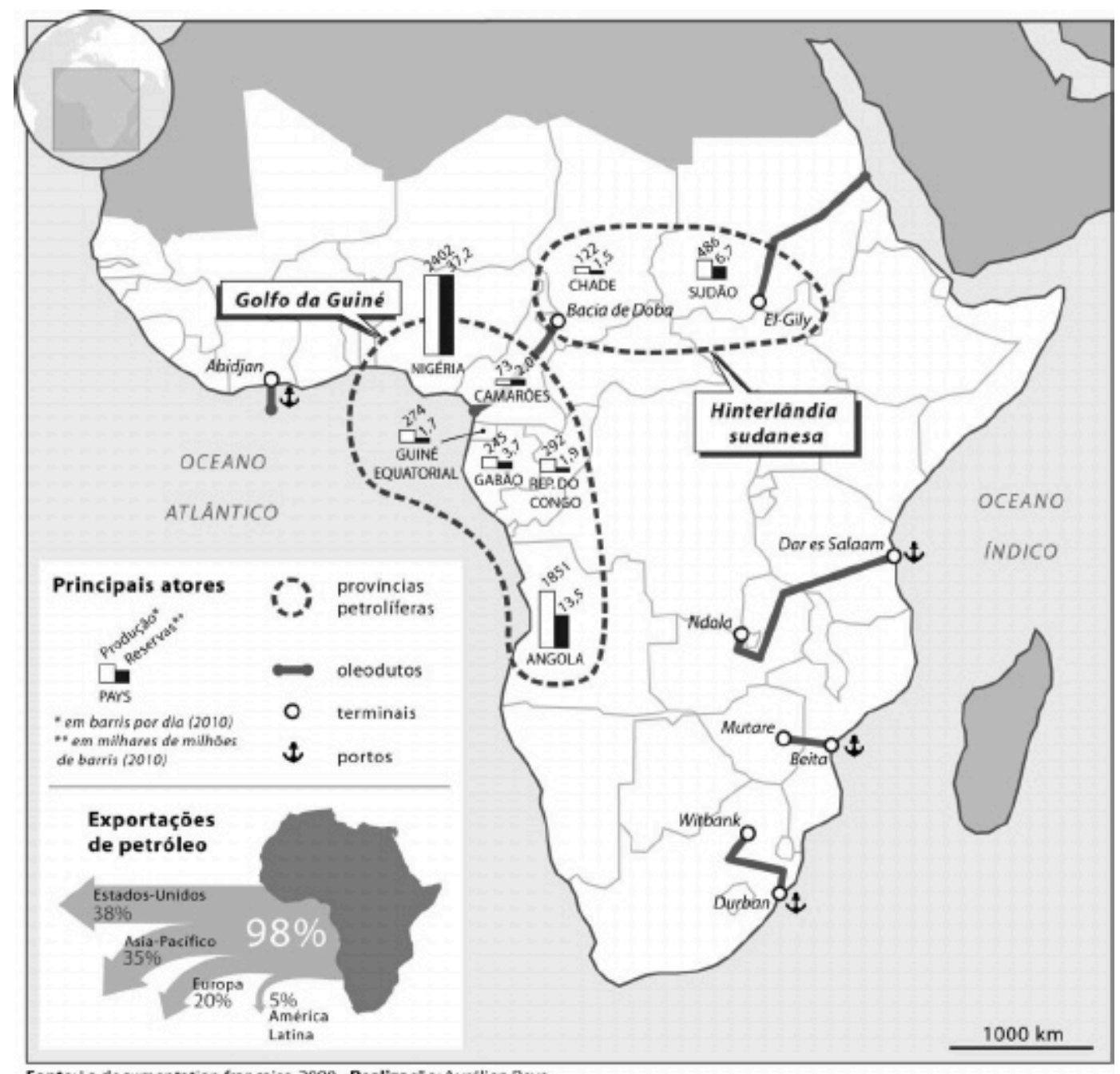

\footnotetext{
Fonte: La documentation française, 2008 - Realização: Aurélien Reys
}

Figura 4: Mapa das principais regiões e países produtores de petróleo.

Fonte: La Documentation Française, 2008. Aurélien Reys.

Paradoxalmente, as riquezas provindas das vendas de petróleo não parecem permitir um enriquecimento de suas populações, nem um desenvolvimento satisfatório dos países da região. Os autores Ukeje \& Mvomo Ela (2013) analisam que o aumento do influxo da renda do petróleo não levou (e não leva) a melhorias nos serviços oferecidos às populações. No caso da Nigéria, que particularmente nos interessa mais, existem ainda acusações de monopólio e corrupção da elite local na captação dos rendimentos, na articulação de redes informais e clientelismo mantidas graças à renda de petróleo, na concessão de exploração de petróleo para as multinacionais estrangeiras ${ }^{50} \mathrm{com}$ a falta de inclusão das populações nas atividades rentáveis.

\footnotetext{
${ }^{50}$ É o caso da companhia Shell.
} 
A descoberta e, sobretudo, a exploração e venda de petróleo, contrariamente, provocou situações explosivas no Golfo da Guiné. Entre elas, a pirataria marítima que passou a ser mais midiática quando houve um aumento significativo do fenômeno em 2009. Neste ano o BMI registrou 58 incidentes ou tentativas de pirataria no Golfo da Guiné, sendo 37 realizados com uso de armas de fogo.

Para se ter uma noção sobre os ataques piratas a nível global, segundo BMI a pirataria marítima mundial passou de 90 ataques recenseados em 1994 nos diversos mares do planeta a 445 ataques em 2003, mas conheceu um declínio passando para 293 atos recenseados em 2008. Dyer (2014) lembra ainda que, 48 ataques ocorreram em 2013, o que representa cerca de 13\% dos registros mundiais.

Embora tenha ocorrido um declínio nos ataques contabilizados a nível mundial a partir de 2008, no Golfo da Guiné este fenômeno continuou sendo crescente e chamando a atenção para um fato curioso - os alvos dos piratas basicamente eram as embarcações comerciais petrolíferas e as companhias de exploração de petróleo instaladas no local. Os ataques, por conseguinte, não se davam de forma aleatória - visando quaisquer embarcações comerciais - e, nem tão pouco se inscreviam no esquema de taxação via sequestros e cobrança de resgate. O que sugeria que os piratas da região marítima atuavam de forma particular e tinham um propósito específico.

Não obstante, os pesquisadores e estudiosos, de modo geral, sempre apostaram na tese da má governança e dos "Estados fracos" para explicar o aumento da pirataria na região. A pesquisa de Ntuda Ebone (2010, p.79) pode ser inserida nessa categoria de estudos. $\mathrm{O}$ autor desenvolve a ideia de má governança como causa principal que provoca atos piratas na região e menciona também o empobrecimento local significativo que leva a população faminta a procurar meios alternativos para sobreviver, a corrupção desenfreada que facilita o escoamento de produtos roubados e a permissividade do Estado em relação às ações de alguns grupos.

Veremos a seguir a argumentação utilizada por alguns autores para defender estas teses como causa do aumento da pirataria no Golfo da Guiné. Também, apresenta-se os contra-argumentos de autores distintos que propõem desconstruir esta "falácia", chamando a atenção para a atuação dos denominados 
piratas na região do Golfo da Guiné. Procurou-se ainda fornecer um breve histórico do contexto geopolítico e econômico do Delta do Níger como forma de trazer mais dados sobre interesses políticos em jogo ligados ao petróleo e algumas limitações do Estado nigeriano na região.

\section{2}

\section{Estados fracos e pirataria no Golfo da Guiné}

Ukeje e Mvomo Ela (2013), defendendo a ideia de fraqueza - e má governança - dos Estados para analisar a pirataria no Golfo da Guiné, chegaram à conclusão de que os Estados locais não conseguiram investir nas suas instituições políticas, nem tão pouco propor os serviços sociais básicos às suas populações. Esses Estados são chamados de "offshore States" 51 , ou seja, Estados cuja sobrevivência depende dos rendimentos de recursos petrolíferos offshore e que não reinvestem os lucros (por diversas razões) em outros setores de suas economias.

Entre outras críticas que recaem sobre os Estados, partem da premissa de que estes não conseguem aplicar suas leis e garantir a ordem nos seus próprios territórios. Sua fragilidade e incapacidade em garantir a segurança do comércio marítimo é, para a Comunidade Internacional, a causa principal que justifica o recurso das atividades criminais que ocorrem na região.

A maioria dessas definições se constroem em oposição (e referência) ao Estado moderno, inspirado pela concepção weberiana de Estado, ou seja, um Estado forte - cuja violência é legítima - capaz de garantir os serviços básicos a seus cidadãos e poder fazer uso da violência para reprimir as atividades criminais no seu território terrestre e nas suas águas territoriais.

Diversos autores (Menkhaus, K, 2003; Eklöf Amirell, 2009; Pérouse de Montclos, 2011), no entanto, discordam desta ideia de "Estado fraco". Pérouse de Montclos, por exemplo, considera essa tese uma falácia e analisa que o cerne da questão está na criminalização do Estado. Por sua vez, Amirell avalia que, a chamada "fraqueza" do Estado pode até favorecer a pirataria, mas não é suficiente para explicar sua existência e seu crescimento.

\footnotetext{
${ }^{51}$ Os "Offshore State" normalmente são acusados pelas deficiências crônicas no apoio financeiro a setores como agricultura, não tão rentável quanto o setor petrolífero.
} 
Em relação aos autores que defendem a tese dos Estados fracos, Amirell (2009) afirma que estes explicam o aumento da pirataria em virtude das limitações do Estado, e ao mesmo tempo, utilizam essa ideia - do aumento da pirataria para identificar e indicar o grau de fraqueza do Estado. O autor sugere que são as dinâmicas da pirataria que devem ser explicadas e postas em comparação com a formação do Estado: ordem interna, centralização local das operações, acumulação de riqueza e exercício de soberania sobre um espaço geográfico claramente delimitado. Stig Jarle Hansen (2009) corrobora as afirmações de Amirell, expondo que ao direcionar o foco ao Estado como o único responsável pela conjuntura política, social e econômica e pela situação de má governança, a teoria desconsidera a relevância e atuação de atores não-estatais, ao passo que sabemos da sua importância na conformação das dinâmicas nacionais.

Ao criticar a tese dos Estados fracos, os últimos autores citados demonstram que existem formas de exercício de poder paralelas ao Estado. Principalmente na África, onde o Estado-nação é uma estrutura relativamente nova. Se o Estado se tornou o principal ator centralizador de recursos, de poder e de violência, não podemos esquecer que se trata de uma situação recente. É o que Thomson (1994) mostrou em seu livro, quando procedeu a uma análise do sistema político através dos séculos, partindo da época medieval ocidental até o Estadonação. Para a autora, o Estado-nação foi criado para propor uma estruturação do poder político. Diante desta nova configuração política, atores à margem da ordem ou atores e indivíduos que já existiam - e não representavam o Estado passaram a ameaçar os interesses desta figura política soberana. A autora cita o caso dos piratas e mercenários que durante séculos fizeram parte de um sistema não soberano de uso da força. Quando o Estado soberano se torna o sujeito principal da organização política, os mercenários e piratas passaram a contestar seus interesses e a representar uma ameaça e uma insegurança para a ordem recém estabelecida que assegurava o monopólio da violência para um ator apenas.

No caso do Golfo de Guiné a argumentação de Thompson é pertinente, já que o modelo político do Estado é extremamente recente - data das independências africanas conquistadas nos anos sessenta. Isso significa que nos períodos anteriores, na era colonial ou na era dos poderes políticos regionais, diversos atores possuíam legitimidade do uso da força num contexto político onde o Estado-nação moderno não existia. Depois das independências, as regiões do 
Golfo de Guiné foram divididas em Estados com delimitação de um território, uma ou duas línguas oficias, agrupando muitas vezes grupos sociais e populações que possuem ou não herança cultural e religiosa comum. As fronteiras atuais são, portanto, resultados da política colonial e das decisões tomadas pelos primeiros governos africanos independentes. No caso da Nigéria, as fronteiras foram estabelecidas após o fim do regime colonial inglês e o país se construiu com base num sistema de federalismo com governos estaduais. Nesse contexto, o Delta do Níger (não confundir com o delta geográfico do rio Níger) é hoje uma região geográfica que nasceu de um projeto político inscrito nos anos sessenta. Nessa época, a região foi delimitada com fronteiras de três Estados. Sob o regime do presidente Olusegun Obasanjo (1999-2007), a região foi ampliada com novos Estados, conforme o mapa a seguir:

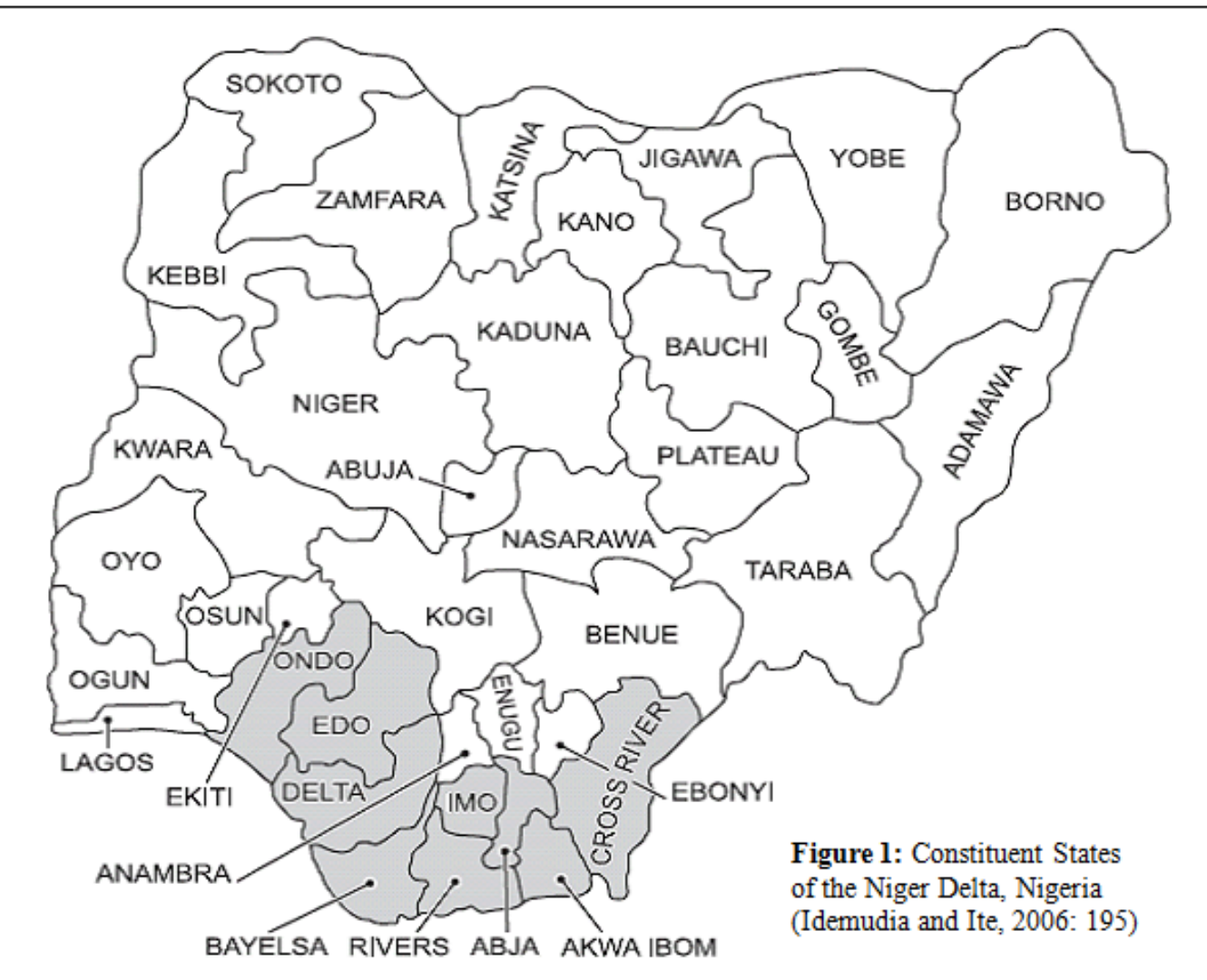

Figura 5: Mapa dos Estados do Delta do Níger. Fonte: Idemudia and Ite, 2006:195

O Delta do Níger possui uma superfície de cerca de $26000 \mathrm{~km}^{2}$ com uma faixa marítima de cerca de $250 \mathrm{~km}$. Segundo Franchette (2006, p.1), em 2005 a 
população era de 10 milhões de habitantes com uma densidade populacional de 600 habitantes por $\mathrm{km}^{2}$. Considerando a sua biodiversidade agrícola, piscícola e marítima convém admitir que a região é de suma importância para o país, já que produz a quase totalidade do petróleo onshore. Até o fortalecimento do governo federal independente (fragilizado pela Guerra do Biafra ocorrida no fim dos anos sessenta), as firmas do Reino Unido - ex-potência colonial - ocupavam um lugar de destaque na exploração do petróleo nigeriano. A British Petroleum se associou a companhia anglo-holandesa Shell para impor as regras do jogo no mercado de petróleo, até ser expulsa pelo governo federal nigeriano em 1979. Conforme Ariweriokuma (2009, p.59), no início dos anos 2000, mais de 90\% do petróleo era produzido por joint ventures contando com o peso maciço das multinacionais (Chevron Texaco, ENI/Agip, Exxon-Mobil, a mais conhecida Shell e Total) e sua associação com a empresa nacional Nigéria Nacional Petroleum Corporation. Vale ainda notar a presença da Petrobras (brasileira) e da China Nacional Offshore Company (CNOC).

O governo federal nigeriano propôs um programa de reestruturação a fim de remediar o desequilíbrio econômico existente entre os Estados produtores de petróleo (Delta do Níger ocupando o lugar de maior produtor) e os outros não produtores. $\mathrm{O}$ autor citado explicita que houve uma drenagem da renda para Estados não produtores de petróleo ${ }^{52}$. Monié $(2012$, p.32) lembra que o rearranjo territorial do Delta do Níger, realizado no início dos anos 2000, objetivou a inserção de regiões menos produtoras de petróleo dentro do Estado para assim garantir a estabilidade política do momento. Através dessa composição, evitar-seiam as possíveis reivindicações políticas de um Estado que então teria monopólio econômico e cuja influência crescente ameaçava o status quo político e os arranjos estratégicos realizados para conter os conflitos entre diferentes grupos sociais. Com isso, percebemos a importância estratégica do Delta do Níger para o governo federal nigeriano.

A seguir, baseando-se em elementos teóricos e empíricos, sinalizamos algumas estratégias e motivações dos piratas no Golfo da Guiné. Utiliza-se noções relacionadas às formas de economias alternativas - "economia política das novas

\footnotetext{
${ }^{52}$ Monié (2012, p. 20) acrescenta que no período de "nigerianização" do setor petrolífero, diversas ações, como a diversificação do tecido industrial com os recursos obtidos pelos setores petroquímico, não foram levados adiante por conta dos custos elevados e de gargalos infraestruturais.
} 
guerras" - para salientar não somente o lado empreendedor dos piratas do Golfo da Guiné, como também as suas atuações como atores políticos na cena regional.

\section{3 \\ A pirataria no Golfo de Guiné e no Delta do Níger: aspectos teóricos, econômicos e políticos}

A maioria dos autores que trabalham a questão da pirataria no Golfo de Guiné (Bateman, 2014; Riols, 2010 e Nincic, 2008) têm se preocupado basicamente com os impactos diretos e indiretos da pirataria e os custos que representam para as economias local e global. Esses impactos constituem, segundo os autores, argumentos suficientes para justificar intervenções militares e garantir a segurança do espaço marítimo ${ }^{53}$. Entre os impactos mencionados constam: o declínio econômico do setor da pesca local; a inflação dos preços dos alimentos; o atraso na entrega de cargas de alimentos e as dificuldades encontradas para as entregas de ajuda humanitária (Bateman, 2014, p.4; Nincic, 2008, p.1; Samiotis et al., 2013, p.3).

Considerando que as Instituições Internacionais, os governos clientes do petróleo africano e a mídia constantemente denunciam as perdas milionárias constatadas nas estatísticas do comércio marítimo, é possível propor uma abordagem assaz original que sugere que os piratas no Golfo da Guiné são atores que usam estratégias já existentes no mercado mundial para suprir suas necessidades econômicas.

Uma análise semelhante foi proposta por Oliveira (2012, p.1-2) e Duffield (2001, p. 139-40 e 2010, p.68) que, ao analisar o caso da Somália, criticam os estudos que associam a pirataria somali ao "nexo segurança-desenvolvimento" defendido pelo CSNU. Se referindo às "economias políticas das novas guerras", os autores observam a existência, por um lado, de uma ordem e paz liberais que moldam os projetos de desenvolvimento econômico e, por outro lado, uma dinâmica local própria que leva à escolha de estratégias de sobrevivência e de ações de desenvolvimento possíveis para seus atuantes.

Oliveira (2012, p.1) argumenta que a pirataria somali não é "a regressão a um estágio pré-moderno de civilização", mas sim a concretização de uma

\footnotetext{
${ }^{53}$ Consultar: Samiotis et al., 2013; International crisis group, 2012; Onuoha, 2013.
} 
racionalidade plenamente integrada à atual lógica da economia global, relacionada à reivindicação do "direito à riqueza" ${ }^{54}$. Segundo o autor (Idem), por conseguinte, a pirataria na Somália se trata de uma economia alternativa que permite um acesso mais eficiente à riqueza e garante modos de acumulação de bens para os seus atores.

Baseando-se ainda nas teorias sobre a "economia política das novas guerras" e nos argumentos de Pugh e Cooper (2004, p.13), Oliveira (Idem) apresenta três estratégicas econômicas das quais se pode referir ao se tratar da pirataria na Somália: 'economia subterrânea' (gerando lucros para enriquecimento pessoal); 'economia de enfrentamento' (gerando recursos básicos de sobrevivência para as populações pobres e marginalizadas); e 'economia de combate' (gerando recursos para a condução da guerra).

Considera-se que as análises propostas pelo autor se aplicam muito bem ao caso do Golfo da Guiné. Mais precisamente no Delta do Níger, onde algumas estratégias econômicas apresentadas acima já representam propostas alternativas de garantia temporária de um desenvolvimento local às margens do Estado nacional e da ordem liberal. É possível notar, inclusive, ethos de partilha entre os piratas, quando se tratava de dividir os lucros do petróleo roubado. O que também dá a entender se tratar de reivindicações sociais e econômicas - ligadas à exploração e o comércio do petróleo, promovidas por indivíduos pertencentes a determinadas comunidades locais. Especialmente as localizadas nos litorais e nos rios da região.

Bizouras (2013), por sua vez, trazendo a discussão para o campo político, sugere que as atividades criminais no Golfo da Guiné sejam interpretadas como formas de protesto contra a situação de desemprego elevado e a ausência de serviços propostos pelos Estados da região às suas populações. Em termos atuais, o autor reformula a ideia de banditismo social inicialmente proposta por Hobsbawm. Propõe pensar os piratas da região do golfo como atores políticos que acionam diversas estratégias para manifestação de seu descontentamento. Fazem

\footnotetext{
${ }^{54}$ Outra perspectiva econômica ousada é a proposta por Leeson (2009, p.10), economista que enfatiza o fato dos piratas atuarem de maneira racional. "(...) everything they did was for a clear economic, selfish motive to maximize their material returns and minimize their risks". Para o autor, pautando para uma perspectiva provocadora, os piratas encontram sucesso nas suas empresas e são os: “(...) capitalists who deftly exercise Adam Smith's Invisible Hand”.In: LEESON, Peter. The Invisible Hook: The Hidden Economics of Pirates. Princeton University Press.
} 
uso da violência, proferem declarações públicas, enunciam problemas e soluções, negociam e representam uma força política contra o Estado.

A abordagem de Bizouras é de extrema pertinência, porém, deve ser distanciada da ideia de que os atores que perpetram atos de banditismo ou de pirataria devam ser vistos como heróis nacionais. Pois, assim como outros atores políticos, estes possuem interesses individuais e, muitas vezes, procuram se enriquecer sob a desculpa de defender os "mais pobres e vulneráveis". A noção de reivindicação social e econômica ou política, por conseguinte, não isenta seus atores de ter interesses individuais, de manipular, construir discursos que defendem seus atos.

O julgamento moral de que os piratas desenvolvem um discurso em defesa dos mais vulneráveis, ou seja, das populações locais, mas se enriquecem com os lucros dos ataques ou ainda se apropriam de um determinado poder, entretanto, não é relevante para o estudo. Dito de outra forma, os interesses financeiros dos atores em lucrar com os ataques, suas estratégias políticas, suas buscas pelo poder coincidem com atividades políticas de modo geral. O jogo da política mundial demonstra que os atores políticos e os militantes sempre defendem interesses individuais e coletivos ao mesmo tempo, usam estratégias diversas, estabelecem alianças, se engajam em determinadas causas e participam de certos conflitos.

O que queremos destacar é o fato de que, em especial no Delta do Níger, os piratas fazem jus ao uso da "violência legítima" (assim como atores estatais e internacionais) e representam realmente um poder político alternativo ao Estado. Têm acesso à tecnologias (por exemplo, GPS) que visam localizar as suas rotas com mais facilidade, possuem pequenas embarcações com grandes capacidades de deslocamento e armamentos de peso. Suas ações são muito bem coordenadas e organizadas e demonstram fazer parte de um amplo repertório, que inclui atuações não só no mar como na terra.

Barrios (2013), por exemplo, menciona a existência de esquemas de corrupção e venda de cargas de petróleo roubado pelos piratas. O autor explica que, o petróleo roubado é transferido para outra embarcação e vendido para terceiros ou no mercado informal em terra, com a cumplicidade de alguns membros dos governos.

Esta estratégia política radical, promovendo o desenvolvimento real em seu contexto local, mas representando, ao mesmo tempo, uma "ameaça 
existencial" para a segurança marítima e energética regional, contudo, tem seus riscos. O maior deles é confrontar diretamente com as estratégias políticas de atores de peso envolvidos na questão de segurança marítima e energética na região. Pois estes têm mecanismos ainda mais eficientes para mobilizar ações políticas com o propósito de neutralizar quaisquer prática tida como ameaçadora para o equilíbrio e para a ordem liberal.

$\mathrm{Na}$ Nigéria, propriamente no Delta do Níger, é possível observar esse confronto direto entre as duas forças. Por um lado, os piratas associados aos movimentos políticos e sociais que atuam na região. Por outro, as forças do governo nigeriano que atuam com o respaldo das Instituições Internacionais e de países estrangeiros com vínculos históricos e econômicos com o país. Ilustra-se esta lide a seguir, tendo como principais atores o Movimento de Emancipação do Delta do Níger e o Governo nigeriano.

\section{4 Insurgências e reivindicações políticas a partir do Delta do Níger: O Movimento de Emancipação do Delta do Níger}

$\mathrm{Na}$ parte anterior, onde destacou-se o papel dos piratas como atores políticos e econômicos, foi sinalizado que os elementos avançados para definir esses atores poderiam também ser aplicados ao caso de estudo da pirataria no Golfo da Guiné, particularmente no Delta do Níger onde se percebe que tais atores estão intimamente ligados à questão da luta pelo poder. Posto isso, julgou-se pertinente citar Copinschi, quando afirma:

O exercício do poder se torna particularmente atrativo por constituir a única via de acesso à riqueza numa economia onde os recursos da renda petrolífera podem ser um fator de imobilismo político para o regime ou, ao contrário, um vetor de lutas políticas que podem degenerar em conflitos abertos (Copinschi, 2003, p. 43).

A afirmação de Copinschi sinaliza um fato importante no caso do Delta do Níger: o exercício do poder se apresenta para determinados atores como a única forma de ter acesso à riqueza. Assim estes buscam pelo poder no seu mais amplo sentido - poder político, militar, econômico e social - visando ter cada vez mais controle dos recursos petrolíferos locais e, porque não dizer, uma maior fonte de renda para as comunidades e população do Delta. Desde 2008, a região, no 
entanto, é supervisionada por um ministério ${ }^{55}$ que procura conter os crimes marítimos e terrestres e visa garantir a ordem e a segurança no Delta.

No mapa a seguir, os pontos em cor laranja representam os campos de petróleo existentes e os traços de cor preta representam os oleodutos. Dois terminais são sinalizados com um ponto branco.

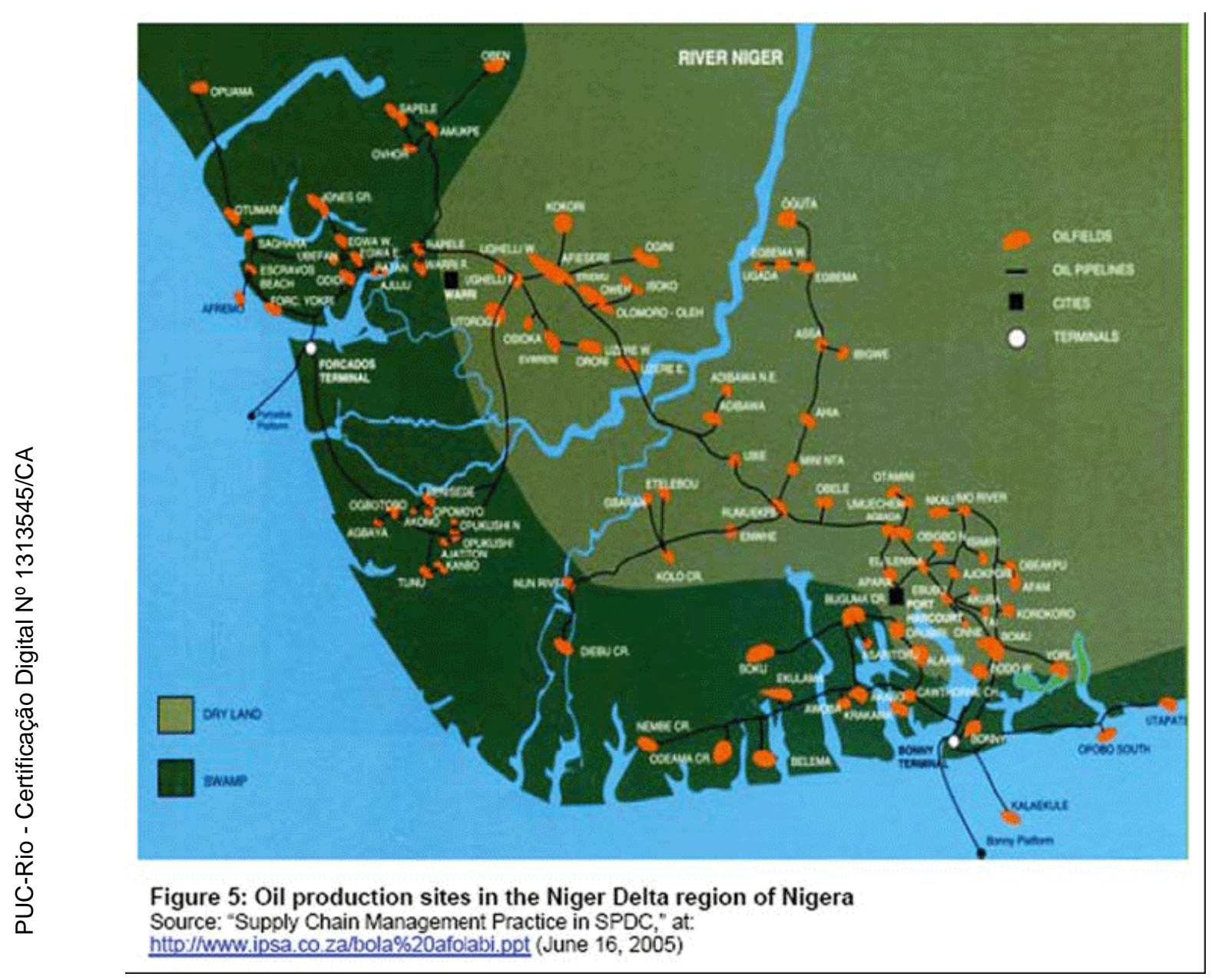

Figura 6: Mapa da produção de petróleo no Delta do Níger.

Fonte: http://ipsa.co.za/bola\%20afolabi.ppt. 16/06/2005.

É possível se ter uma noção do quão envolvida na exploração do petróleo está a região do Delta Níger e, ao mesmo tempo, o quão difícil é para o governo nigeriano dar conta da sua complexidade. Provavelmente seja por essa razão que o atual presidente da Nigéria, Umaru Musa Yar'Adua, priorizou, na sua agenda política, a resolução da insegurança na região atribuída aos piratas e ativistas armados de movimentos políticos que criticam a sua atuação.

\footnotetext{
${ }^{55}$ O site oficial é: http://www.nddc.gov.ng/
} 
Desde que alguns movimentos políticos iniciaram a luta armada, a Nigéria viu reduzida drasticamente a sua capacidade de extração e perdeu boa parte das suas receitas da venda de petróleo bruto. Uma estimativa afirma que o país perdeu até 500000 barris por dia numa produção diária de 2 milhões em 2008. Em março de 2009 os dados oficias anunciados eram de 1,6 milhão de barris por dia enquanto em 2006 era de 2,6 milhões (Augé, 2009).

A atuação dos piratas - e mais especificamente do MEND - provocou grandes preocupações ao governo e a Joint Task Force (JTF), força aérea, exército e marinha do governo nigeriano, foi designada para o Delta do Níger para resolver a situação. A JTF procura obter constantemente informações sobre o MEND, sua forma de atuar, suas estratégias e as armas que possui. Os habitantes sofreram as consequências da militarização da região e acusaram o governo nigeriano de ter deslocado essa força tarefa para garantir a segurança das multinacionais em detrimento de sua segurança.

O governo nigeriano oscila constantemente entre organizar ofensivas militares contra os piratas - ações apoiadas pela OMI e a BMI - e negociar com os piratas. Foi assim que se deu a anistia de 2009. Na ocasião, o presidente nigeriano Umaru Yar'Adua prometeu a anistia aos militantes do MEND, caso eles suspendessem imediatamente suas atividades piratas. Um relatório do United Nations Office On Drugs and Crime (UNDOC) anuncia o número de $26000^{56}$ militantes que teriam abandonado as armas na ocasião. O relatório ainda enfatiza que o governo teria prometido uma melhor distribuição das receitas provindas do petróleo aos governos do Estado do Delta ${ }^{57}$.

Dr. Ebikabowei Victor Ben, aliás 'General Boyloaf', foi anistiado em 2009. Na entrevista realizada no dia 07/09/2013, e apresentada aqui, o exmilitante chamado Boyloaf é interrogado por Soni Daniel, editor regional. O título do artigo publicado foi: "Why Niger Delta oil theft can't stop". Durante a entrevista, Boyloaf acusou o presidente Yar'Ádua de não ter cumprindo as promessas feitas no momento da anistia e isso justificaria o fato do MEND ter retomado seus ataques. As multinacionais também são acusadas quando o

\footnotetext{
${ }^{56}$ Outros mencionam um número menor de 8000 . < $<$ ttp://www.afrinewscentre.com/pt/africa1/africa-ocidental/1607-piratas-sequestram-dois-marinheiros-americanos-da-nigeria.html $>$ Acesso em: 18/12/2014.

57 Informações disponíveis em: http://www.unodc.org/documents/data-andanalysis/tocta/West_Africa_TOCTA_2013_PT.pdf $>$ Acesso em: 17/12/2014.
} 
entrevistado afirma: "Nigerians must be made to know clearly that over 75 percent of the oil said to be stolen in the Niger Delta belongs to the security agencies and they must be held responsible for the rising theft" (in: Daniel, 2013). ${ }^{58}$

O entrevistado anuncia que enquanto o governo federal não tomar medidas compensatórias a favor das populações do Delta, os roubos de petróleo continuarão. Segundo Boyloaf, é a incompetência e o desleixo do governo federal que provocam o roubo de petróleo. Boyloaf ainda não concorda com o fato dos piratas serem chamados de ladrões já que eles fazem apenas uso do que lhes foi dado por Deus:

I hate to hear the word 'oil thieves or oil theft' because the people you want to label as thieves are simply trying to make use of their God-given resources. In other words what they are doing is the legitimate 'resource control' that we have been talking about. The truth of the matter is that the Niger Delta people are simply controlling their resources and not stealing any oil (in: Daniel, 2013).

Além do MEND, existem outros movimentos políticos heterogêneos ${ }^{59}$ no Delta do Níger. Um deles, o Movement for the Survival of the Ogoni People (MOSOP) adquiriu uma grande visibilidade na mídia internacional graças à figura carismática de Ken Saro-Wiwa, seu líder, que reivindicava resistência pacífica dos habitantes através de manifestações populares na rua, sabotagens de oleodutos (...) para defender seus direitos. No entanto, foi com o movimento Niger Delta People's Volunteer Force (NDPVF), em 2004, e o Movement for the Emancipation of the Niger Delta (MEND) no fim de 2005, que a resistência armada passou a ser escolhida pelos ativistas nigerianos em geral, que consideravam que esta era a forma mais eficaz de intimidar o governo federal e as multinacionais. Segundo Pérouse Montclos (2011) a mudança política de uma oposição pacifista à luta armada foi uma mudança estratégica que coincidiu com a consolidação de meios criminais urbanos nas cidades litorais de Port Harcourt e Warri.

Avalia-se que existe cerca de 90 campos de militantes do MEND em toda a região do Delta do Níger. O "campo 5" - um dos ramos mais ativos e

\footnotetext{
${ }^{58}$ Vanguard, 07 de setembro de 2013.

${ }^{59}$ Ogege (2011, p. 253) cita o Movement for the Survival of theIjaw in the Niger Delta (MOSIND).
} 
conhecidos - conta com cerca de 1000 combatentes. Augé (2009) menciona a participação de líderes de outros grupos (Exemplo: Ateke Tom, líder do Niger Delta Vigilante Movement) presentes neste campo. Este também conta com a presença do "General Officer Commanding" (GOC) que, por sinal, é irmão do presidente do governo local de "Warri Southwest".

Os militantes mais conhecidos são: Ateke Tom, Boyloaf (Ebikabowei Ben) Aka Boyloaf, Egberipapa (Soboma Jackreece), Farah Dagogo, Tom Polo, Soboma Jacrich. Esses se entregaram no momento da anistia de 2009, juntamente com outros militantes famosos como Henry Okah (mencionado na introdução do trabalho). Cita-se ainda o militante Jomo Gbomo que teria sido durante muito tempo o porta-voz do MEND e Akpos Mezeh seu secretário. Os membros do MEND, pelo menos os que possuem cargos de responsabilidades, têm nomes ou apelidos e são conhecidos, o que facilita a análise sobre os seus atos piratas e dos seus discursos.

Na prática, as atividades do MEND, tais como bunkering e contrabando de petróleo bruto são as mais recorrentes. Todavia, com a escalada da violência na região, o movimento também passou a cometer alguns raptos de membros de tripulação estrangeira e assassinatos de soldados policiais - supostamente agentes secretos que tentaram infiltrar no grupo.

As suas ações são diversas e sempre anunciadas na imprensa (envio de comunicados e fotos para dar informações sobre os atos cometidos, carta com suas reivindicações, etc.). O MEND dialoga com a imprensa de maneira constante, nega certas acusações ou confirma alguns ataques, como podemos ler no trecho a seguir: 
Depois de ter violado a nossa interdição, concernente aos navios petroleiros que transportam gás ou produtos químicos, de se aproximar das águas do Delta do Níger, seis membros da tripulação que trabalham no navio Siehem Peace foram sequestrados até à nova ordem", anunciou o MEND. A sua detenção deve servir de exemplo para mostrar que existem problemas internos que devem ser resolvidos com o Governo nigeriano, tais como o regresso das populações deslocadas às suas terras de origem, a indemnização pelos danos sofridos, o recuo da força de intervenção conjunta para as casernas e, finalmente, uma emenda à constituição para modificar a fiscalidade federal antes que a situação volte à normalidade", afirmou o movimento separatista nigeriano.

O grupo militante adverte que o próximo navio petroleiro que for interceptado terá menos sorte pois, prometeu que ele será queimado e os membros da tripulação serão evacuados. O MEND retomou recentemente os seus ataques contra as infra-estruturas petroleiras no Delta do Níger na sequência da ofensiva militar lançada contra os seus militantes em meados de maio último." 60

Como foi apresentado acima, é possível constatar que o MEND é um movimento político articulado que possui ainda uma organização hierarquizada, sem líder "visível” (Augé, 2009, p. 19). Os membros parecem beneficiar-se do apoio dos habitantes da região e de atores locais e, possuem legitimidade para falar em seus nomes. Contudo, Asuni (2009, p. 12) afirma que a intimidação também foi e é posta em prática por parte de membros do MEND para garantir esse apoio ou obrigar as populações a ajudá-los.

Além do apoio da população, várias figuras carismáticas do país manifestaram seu apoio ao MEND. É o caso de Wole Soyinka, prêmio Nobel de literatura nigeriano, que escolheu fazer parte da equipe que falou em nome do MEND quando o governo federal propôs negociar com seus membros e pôr termo à violência na zona petrolífera do país.

Em suma, essencialmente em Nigéria, os ataques piratas emanam principalmente de grupos e movimentos políticos organizados e com forte engajamento no contexto social. Boa parte dos movimentos apresentam intenções políticas que visam a destruir capacidades produtivas da Nigéria e defender os direitos dos habitantes locais. Autores como Michael Watts (s.d. p. 80), todavia, defendem que o objetivo principal destes movimentos é apenas o lucro.

Optamos, no entanto, pela distinção elaborada por Augé (2009), que corrobora a ideia de que atores políticos e militantes sempre defendem ao mesmo tempo interesses individuais e ideias políticas. Pois tais atores apresentam uma

\footnotetext{
${ }^{60}$ Fonte: <http://www.panapress.com/Seis-membros-de-tripulacao-de-navio-petroleiro-raptadosna-Nigeria--3-434471-51-lang1-index.html>. Acesso em06 de julho de 2009.
} 
perspectiva de lucro financeiro e uma perspectiva política voltada para a questão do poder no Delta.

De acordo com a opinião de Jomo Gbomo - porta-voz do MEND - o objetivo do Movimento é destruir totalmente a capacidade do governo nigeriano de exportar petróleo e obrigar as multinacionais a reverem suas políticas de exploração. O MEND, portanto, se inscreve no grupo de atores que possui uma perspectiva política e financeira. Com efeito, o MEND constrói sua imagem de movimento político e acusa o governo federal nigeriano e as multinacionais de serem os principais responsáveis pela situação vivida pelas populações do Delta do Níger. É extremamente dinâmico, sendo objeto de discórdias políticas entre membros que, como em qualquer outro movimento político, disputam o poder.

Todavia, baseando-se na definição jurídica sobre a pirataria o MEND sequer poderia ser considerado como um grupo pirata pela comunidade internacional. Existe, no entanto, uma extrapolação das definições da pirataria (definições genéricas e definição jurídica) que leva atores internacionais e regionais a classificarem atos criminosos cometidos nas águas territoriais, nos rios, e por vezes em terra, como tal. O conjunto de informações que conseguiu-se recolher sobre o MEND corrobora portanto a tese de que a securitização da pirataria leva à despolitização de questões internas como, por exemplo, atitudes do governo federal frente ao Estado do Delta.

Neste capítulo, constatou-se diversos aspectos da pirataria no Golfo de Guiné e no Delta do Níger. Observou-se que os autores que constroem uma visão mais complexa da pirataria rompem com a ideia simplificadora de que os piratas são somente indivíduos cruéis, perversos e oportunistas. Os autores mencionados apelam para a dimensão política e econômica dos atos piratas, evidenciando a participação ativa desses atores na cena nacional. Suas reivindicações e sua atuação no âmbito político e econômico nos leva a considerar que os piratas são sujeitos de suas histórias e de suas próprias realidades e propõem alternativas que respondem às suas necessidades, ansiedade pelo poder e interesses no enriquecimento, como qualquer outro ator político. Ao repensar a pirataria a partir dessas análises inovadoras, constatou-se que essas poderiam ser utilizadas para melhor entender a pirataria no Golfo de Guiné. Por esta razão, após uma breve contextualização do Golfo de Guiné e da questão do petróleo na região intimamente ligada ao recrudescimento dos atos piratas - apresentou-se a questão 
da pirataria no Delta do Níger. Verificou-se que as reivindicações políticas dos piratas representam apenas parte das explicações para entender as modalidades do fenômeno. Cabe lembrar que o Golfo da Guiné é a maior região provedora de petróleo na escala do continente africano, portanto não é possível entender o contexto político atual e os atos piratas sem levar em consideração os interesses e jogos políticos que se efetivam entre atores internacionais, nacionais ou ainda regionais.

Veremos a seguir algumas explicações sobre este contexto. Em âmbito local, apresentamos algumas estratégias adotadas pelo governo nigeriano; em âmbito internacional estuda-se brevemente a atuação de atores políticos como a França - no horizonte do Critical Maritime Route in Gulf of Guinea (CRIMGO) e, os Estados Unidos - no quadro da sua política de segurança para África (AFRICOM); e, em âmbito regional, trazemos algumas reflexões sobre a atuação dos Estados africanos na luta contra a pirataria e sobre o regionalismo africano. 


\section{4. REFLEXÕES SOBRE AS SOLUÇÕES ADOTADAS CONTRA A PIRATARIA E A NOÇÃO DE SEGURANÇA NO GOLFO DA GUINÉ}

A pirataria marítima, como acabamos de constatar, é um tema que constantemente envolve discussões diversas e calorosas. É difícil saber quais são as verdadeiras causas que provocam a pirataria $^{61}$ e esse fenômeno possui múltiplos significados, construídos a partir de perspectivas e interesses diversos. Analisa-se aqui soluções que já foram utilizadas ou aplicadas pelos atores políticos envolvidos na luta contra a pirataria, com objetivo de defender seus interesses.

Conforme abordado anteriormente, o Golfo da Guiné tornou-se um espaço com aumento significativo de crimes marítimos e, mais especificamente, de atos de pirataria. Embora países como Benim, Camarões e Angola tenham sofrido ataques, a maioria destes aconteceram ao longo do litoral da Nigéria e ao largo de portos nigerianos: Calabar, Lagos e Port Harcourt. Atos de banditismo, como vimos, ocorrem também em suas águas territoriais, principalmente em torno do Delta do Niger. Estes crimes marítimos preocupam o governo federal nigeriano e os compradores estrangeiros de petróleo, que passaram a definir pirataria como ameaça existencial e permanente.

$\mathrm{Na}$ maioria das vezes, o governo federal qualifica as operações de grupos armados como “insurreição". Conforme Augé (2009), a palavra “terrorismo” é utilizada pelo governo federal nigeriano para definir a natureza de tais operações. O documento "Prevention for Terrorism Bill", define de maneira ampla o que é terrorismo e as ações que podem ser tomadas pelo poder central para atuar contra esse fenômeno. A Terrorism Prevention Act de 2011 - com elementos votados pelo senado em 2012 e em 2013 - autoriza, por exemplo, a pena de morte para os atores de atos terroristas ${ }^{62}$. Vale destacar que militantes e ativistas dos movimentos do Delta do Niger são considerados "terroristas potenciais", mas são julgados pela Territorial Waters Act.

\footnotetext{
${ }^{61}$ Mesmo quando o consenso existe, é muito difícil garantir a eficiência das soluções para eliminar os atos piratas da região.

${ }^{62}$ Para mais informações, consultar: <http://www.nigerianwatch.com/news/1334-nigerian-senatepasses-new-anti-terrorism-act-with-death-penalty-for-offenders\#sthash.wEC8ZKkz.dpuf $>$. Acesso em: 13/01/2015.
} 
Em matéria de erradicação da pirataria e banditismo no Golfo de Guiné, a Nigéria $^{63}$ é considerada uma exceção ${ }^{64}$ em relação aos seus vizinhos, que, conforme apontam atores internacionais, possuem uma capacidade de defesa marítima e terrestre incipiente. Na tabela abaixo constam dados dos últimos três anos sobre atos piratas que ocorreram nas águas territoriais da Nigéria e em alto mar próximo ao espaço de jurisdição do país. O BMI, autor desses dados, afirma que 117000 toneladas de produtos petrolíferos foram roubados desde 2010 até 2014, o que equivale a 100 milhões de dólares.

\begin{tabular}{|c|c|c|c|}
\hline & 2011 & 2012 & 2013 \\
\hline Ataques a navios & 97 & 46 & $\begin{array}{l}59 \text { (cerca de } 31 \\
\text { apenas na Nigéria } \\
\text { e } 263 \text { registrados } \\
\text { em todas as águas } \\
\text { marítimas) }\end{array}$ \\
\hline Roubos $^{65}$ & 66 & 64 & 86 \\
\hline Total & 163 & 110 & 145 \\
\hline
\end{tabular}

Tabela 1: Dados 2011-2013.

Fonte: BMI, 2013.

A comparação entre os dados de 2011 e os de 2013 revela uma diminuição dos atos piratas. Ainda assim, atores internacionais - a França ${ }^{66}$ por exemplo - e nacionais, manifestam sua apreensão em relação aos atos cometidos em 2013 e alertam as autoridades nacionais e regionais para o fato de que seus interesses continuam sendo ameaçados. A Nigéria valida esse tipo de declaração e tem demonstrado vontade política clara em relação à luta contra a pirataria e o terrorismo em geral, sobretudo à luz dos últimos eventos que ocorreram no norte do país ${ }^{67}$.

\footnotetext{
${ }^{63}$ A formação e o treinamento do pessoal da marinha nigeriana foram realizados por Missões Militares da "Royal Navy". Informação disponível no site da Oficial Nigerian Navy: www.navy.mil.ng. Acesso em: 07/02/2015.

${ }^{64} \mathrm{O}$ orçamento anual da Nigerian Navy é de 279 milhões de dólares, (o que representa $20 \%$ do orçamento total do ministério de defesa). A Marinha nigeriana possui fragatas, navios e lanchas de patrulha (...) e conta com guarda costeira e Força formada para atuar em operações complexas.

${ }^{65} \mathrm{~A}$ definição dada aos roubos é: delitos praticados dentro de áreas que pertencem à jurisdição de um Estado.

${ }^{66}$ Consultar:http://www.diplomatie.gouv.fr/fr/IMG/pdf/_PresentationVRLauCESD_cle895c1e.pd f. Acesso em: 10/02/2014.

${ }^{67}$ Para mais informações sobre os acontecimentos ocorridos em janeiro de 2015 na Nigeria, consultar: http://fr.groupegeos.com/veille/[GEOS]_Note_mensuelle_Nigeria_janvier2014.pdf.
} 
Em relação à sua dinâmica política interna, salientamos que a guerra do Biafra, de 1967, configurou o contexto político atual. Ou seja, parte das tensões atuais entre o Delta do Níger (antes da ampliação de suas fronteiras) e outros Estados se origina na guerra do Biafra. Cabe sinalizar que, no final dos anos setenta, dez anos aproximadamente depois da guerra, o governo federal institui the Land Use Act ${ }^{68}$ que estipula que os recursos mineiros e fundiários pertencem ao Estado nigeriano. Desde então, o governo federal procura administrar os conflitos existentes dentro da região do Delta e entre os diferentes Estados que compõem o país. Entre as iniciativas e tentativas do governo para instaurar um equilíbrio social e político no Delta do Niger, selecionou-se algumas ações que pareceram significativas e representativas.

Em 2000, o presidente Olusegun Obasanjo criou a Niger Delta Development Commission (NDDC) com intuito de financiar projetos econômicos para o Estado do Delta do Niger. No entanto, o orçamento da comissão foi diminuindo a cada ano, o que dificultou o trabalho dessa comissão até torná-la obsoleta. Em 2006, foi criada a Joint Task Force - JTF (citada no último capítulo). Como mencionado, várias críticas surgiram em reação às ações dessa Força tarefa. Até hoje, esta não conseguiu controlar os diferentes movimentos da região. Segundo Ogege (2011, p.252), a $\mathrm{JTF}^{69}$ é considerada ineficaz ${ }^{70}$ e é acusada de estar envolvida em diversos atos violentos (genocídio em Ogoni em 1993 ou massacres em 1999 e 2009). Frynas (2001, p.50 e 51) lembra que algumas multinacionais participaram (e participam ainda) de ações violentas contra as populações e os grupos militantes e justificam seus atos (e as ações repressivas do Estado nigeriano) pela preocupação com sua segurança que seria ameaçada, já que operam em zona considerada de riscos e conflitos.

\footnotetext{
Acesso em: 12/02/2015.

${ }^{68}$ Com a aprovação do Land Use Act em 1978, o governo federal nacionalizou as terras. Os Estados recebem o pagamento da renda das terras e não aos donos da terra (Frynas, 2001, p. 30). A partir da aplicação da lei, as multinacionais passaram a pagar compensações (mas apenas quando há destruição de algo) aos governadores regionais (e não às comunidades). As comunidades e populações locais não podem questionar a instalação de uma multinacional em "suas" terras. Se, historicamente, as terras pertencem a determinada comunidade, ela perdeu o direito de propriedade com a adoção da lei de 1978. A legislação é também muito vaga sobre a questão dos pagamentos às comunidades afetadas pela poluição ambiental causada por multinacionais.

${ }^{69}$ Segundo Amunwa $(2011$, p.9) a JTF protege as atividades da Shell através da presença de uma força armada no local de suas operações e considera que é da responsabilidade do Estado e não sua garantir sua segurança. As forças do governo dependem em muito do apoio da Shell, que chegou a contratar forças governamentais para proteger seus próprios interesses.

${ }^{70}$ Suspeita-se que certos membros integrantes dessa força tarefa estão envolvidos em esquemas de roubo de petróleo. International Crisis Group, p. 5.
} 
Com o presidente Yar'Adua, em 2008, iniciou-se a criação do ministério (mencionado anteriormente) dedicado a questões diversas relativas ao Estado do Delta. O Ministério tinha - entre outros objetivos - atuar em prol da juventude do Delta do Níger e propor melhorias nas infraestruturas da região. Mas assim como a NDDC, sofreu baixas no seu orçamento e não tinha objetivos políticos claros. $\mathrm{O}$ ministério não conseguiu cumprir seu papel por conta de limitações políticas e financeiras. Assim, apesar das tentativas dos sucessivos governos em solucionar as questões políticas e econômicas ligadas ao estratégico Delta do Níger e controlar o início da luta armada e roubos de petróleo de certos movimentos desse Estado, a Nigéria chegou a perder, segundo Augé (2009), até 500000 barris por dia (até 2008) ${ }^{71}$.

No mesmo ano, outra instituição de peso foi criada: Niger Delta Technical Committee. Após análise minuciosa de todos os relatos produzidos desde os anos sessenta e depois de consultar todos os atores envolvidos (inclusive os movimentos armados) - este comitê elaborou propostas no seu relatório final, tais como: a proposta da anistia de membros de movimentos armados e sua reinserção social (que será recuperada pelo então presidente um ano mais tarde); o aumento dos rendimentos do petróleo recebidos pelos Estados do delta do Níger (13\% para $25 \%)$.

O programa de anistia de agosto de 2009 proposto por Yar'Adua consistia em ajuda financeira e governamental para os militantes que se prontificassem a abandonar as armas e seus respectivos grupos de militância. A ajuda financeira equivalia a um valor de 65000 nairas por pessoa. Augé (2009) lembra que o orçamento total desta operação foi de 65 bilhões de nairas. Ogege afirma que:

The amnesty programme became an inevitable response to the inability of the Military Joint Task Force with its heavy artillery and weaponry to ensure a peaceful environment for interrupted exploration and exploitation to raise the revenue base derivable from oil production. The Nigerian state was desirous to create an enabling business climate for the multinational oil companies to operate unencumbered (Ogege, 2011, p.253).

A anistia $^{72}$ foi escolhida como estratégia para diminuir a violência e os

\footnotetext{
${ }^{71}$ Segundo uma fonte oficial do governo francês, Inauguration du Centre inter-régional de coordination pour la sûreté maritime dans le golfe de Guinée (CIC), janeiro de 2014, atualmente contabiliza-se 300000 baris roubados por dia.

${ }^{72}$ Catherine Yang, « Less blood for oil, Nigeria's fragile amnesty », Harvard International Review
} 
sequestros que estavam ocorrendo. Continha promessas de renegociar a distribuição das receitas de petróleo e organizar uma conferência nacional sobre o Delta do Niger. Não há unanimidade quanto ao número de pessoas que aceitaram se render: segundo Rémy (2010, p.6) entre 15000 e 20000 militantes; segundo Ogege (2011, p.254) 20192 militantes (todos movimentos confundidos: Federated Niger Delta Ijaw Communities (FNDIC), Ijaw Youth Council (IYC), Movement For the Survival of the Ijaw Ethnic in The Niger Delta (MOSIEND), Movement for the Emancipation of Niger Delta (MEND), etc) teriam se inscritos, mas apenas entre 6 a 8000 membros se renderam efetivamente. $O$ valor da compensação financeira era muito aquém do esperado e do que os membros recebiam enquanto militantes. Tendo em conta a resistência dos militantes do Delta do Níger em se renderem e os muitos obstáculos existentes para iniciar o processo de paz em Nigéria, a anistia foi, a curto prazo, considerada um sucesso e em seguida um fracasso. Ogege avalia nestes termos:

\begin{abstract}
Between 6th August 2009 when the disarmament (the first phase of the amnesty programme) commenced and October 4, 2009 when it ended, 20,192 militants comprising 20,049 males and 133 females respectively across the nine states of the Niger Delta denounced militancy and registered for the amnesty programme. Those that accepted the amnesty offers, surrendered their weapons of war to security forces at different designated collection centers. The conditional amnesty offer gave the militants the opportunity to renounce violent agitations. It is worthy to note without equivocation that the amnesty initiative successfully but temporarily put an end to militancy and insecurity in the region thereby paving way for uninterrupted exploration and exploitation by the multinational oil companies (Ogege, 2011, p. 254).
\end{abstract}

A criação de (inúmeros) comitês encarregados de analisar a situação do Delta do Níger e propor soluções para o delicado problema de gestão do petróleo também não trouxe a aplicação de soluções concretas esperadas ao longo prazo.

O Estado nigeriano, apesar das várias medidas tomadas ao longo desses últimos 30 anos, não conseguiu reverter a situação de desequilíbrio e insatisfação das populações locais, o que resultou em grande perda de credibilidade. A "Reform Conference 2005" não resolveu as tensões existentes entre a delegação da região do Delta e as outras delegações nigerianas. O governo federal é constantemente obrigado a intervir para tentar equilibrar as forças políticas no 
norte e sul do país, tendo que mediar a questão principal dos dividendos do petróleo, que gera desacordos entre os diferentes Estados nigerianos. O Estado não conseguiu se impor nem pela força nem pela negociação (anistia, por exemplo) aos movimentos armados ou às companhias petrolíferas estrangeiras. $\mathrm{O}$ resultado foi, entre outros, a militarização dos seus atos em nome da segurança nacional com repressões violentas ao longo das três últimas décadas.

Cabe ressaltar que por conta dos enormes recursos provenientes do mercado paralelo e contrabando de petróleo, os militantes possuem equipamentos e tecnologia de ponta, que lhes permite realizar ações até em alto mar, com o objetivo de atingir instalações petrolíferas ou navios estrangeiros (International Crisis Group, 2007: 11). Isso dificulta as operações do governo federal e sua capacidade em controlar movimentos armados. O governo federal tem ainda dificuldade em propor uma dinâmica política na qual poderia contar com atores locais do Delta do Niger. Os Estados que compõem a atual região do Delta do Níger participam ativamente da vida política nacional e local. São eles que recebem os dividendos das receitas do petróleo e são ainda os mediadores políticos entre o governo federal e os grupos armados. Muitos governadores locais apoiam as reivindicações dos grupos armados no que toca a proposta de um aumento do valor das receitas petrolíferas. Aliás, Augé (2009) não descarta a hipótese de um apoio dado pelos governadores locais aos militantes do Delta do Niger.

Antes de adoecer, o presidente Umaru Yar'Adua chegou a propor diversas medidas consensuais, por exemplo: a instauração de uma taxa de poluição que seria paga pelas companhias exploradoras de petróleo nacional e um aumento da redistribuição dos lucros de petróleo. Vale destacar que com a distribuição atual, as regiões que possuem petróleo continuam recebendo apenas $13 \%$ dos lucros do petróleo que elas produzem, o que não corresponde aos $25 \%$ ou $50 \%$ sugeridos pelos militantes. Com o falecimento de Yar'Adua em 2010, essas propostas não foram levadas adiante pelo seu sucessor. A eleição do presidente da república Goodluck Jonathan não trouxe esperanças em relação ao aumento dos lucros do petróleo $^{73}$.

\footnotetext{
${ }^{73}$ Segundo a agência de imprensa, o presidente Goodluck Jonathan trabalha (desde 2012) sobre um projeto de lei visando a aumentar as receitas do petróleo do governo federal e reestruturar a companhia de petróleo nacional (NNPC). No entanto, até hoje, esse projeto de lei visando a
} 
Os conflitos e tensões existentes atualmente no Delta do Níger ameaçam um governo federal já frágil e mostram que, apesar das diferentes tentativas dos governos entre o uso da força e a negociação com anistia, os movimentos insurgentes se fortalecem e não desaparecem. O Estado perdeu sua credibilidade com as populações, já que as questões sociais permanecem pendentes - segundo relato do PNUD (2006, p.iii), as condições das comunidades moradoras em terras de exploração de petróleo continuam críticas, sem acesso à água potável, para citar apenas um exemplo.

O contexto acima apresentado, com comentários sobre a situação do Estado nigeriano, permite entender a relatividade do conceito de segurança e o quanto este está relacionado às necessidades do governo, partilhadas pelos atores internacionais que agem movidos pelos seus próprios interesses. A segurança enquanto construção social da realidade ${ }^{74}$ - passa a ser um conceito que responde às demandas dos atores e às suas preocupações em termos de poder, medo e riscos.

Não há dúvida que nessa situação - e apesar de possuir a frota mais equipada da região - a Nigéria encontra-se fragilizada dentro de suas próprias fronteiras, mas também em termos regionais. Isso me permite trazer à tona a discussão sobre o papel do Estado diante dos conceitos de segurança e securitização da pirataria, que passaram a ser discutidos nas redes globalizadas nas quais o Estado possui uma credibilidade menor e um espaço de atuação reduzido. Nesse sentindo, Jan Aart Scholte (1996) ${ }^{75}$ considera que a globalização provocou a criação de uma dimensão supra territorial, na qual se tecem as relações sociais que provocam a diminuição do espaço de ação do Estado. Esse já não é mais a figura proeminente e legítima que representa a autoridade política nacional.

Vimos, em capítulo anterior, que os atores não estatais participam de diversas redes sócio-eco-políticas e estabelecem novas dinâmicas que influenciam a ordem estabelecida pelo Estado. Esta é constantemente revisitada por esses atores que, atualmente - e na era de globalização contemporânea - possuem

\footnotetext{
reforma energética não foi apresentado oficialmente.

${ }^{74}$ Para mais informações, consultar Karacasulu e Urgozen, 2007, p. 38; Krause; Williams, 1996, p. 243.

${ }^{75}$ Disponível em: http://originwww.unicef.org/socialpolicy/files/Global_Civil_Society_Changing_the_World.pdf. Acesso: $15 / 02 / 2015$.
} 
espaços de expressão, contestação e redefinição e fazem jus das redes globais para atuar.

No caso estudado aqui, as medidas de contestação, em reação aos discursos e atos do governo federal e das multinacionais, são cada vez mais violentas e visam a desconstruir essa ordem. Os militantes se relacionam diretamente com as multinacionais sem contar com Estado como intermediário.

Mann (1999) ${ }^{76}$ considera que a relevância das redes globais levou a uma perda de centralidade do Estado, que não é mais o único ator a enfrentar problemas de segurança. Atores internacionais estão sendo alvos de ameaças e atos piratas e, por essa razão, passaram a interferir nas políticas nacionais dos Estados africanos. Ao construir uma ameaça comum, partilhando as mesmas preocupações em relação à segurança marítima do Golfo de Guiné, atores extra regionais ou extra territoriais se tornaram uma força política incontornável em assuntos internos ao país.

A definição do conceito de segurança basicamente não depende mais do ponto de vista do Estado, que possui - como soberano - o monopólio da violência e o monopólio dos discursos que produziram e construíram a imagem do inimigo - o pirata. O Estado nigeriano ainda assim tenta atuar como ator principal na dinâmica de segurança regional, porém, se vê sobrecarregado com os problemas sociais a serem solucionados. A seguir, analisa-se a atuação França que vem impondo sua perspectiva em relação à luta contra a pirataria na região.

\section{1}

\section{A perspectiva francesa (e europeia) sobre a questão da segurança marítima no Golfo de Guiné}

A segurança é, antes de qualquer análise, um termo carregado de valores e subjetividades. Com isso, e em base na teoria de securitização apresentada no primeiro capítulo, avalia-se a segurança enquanto política e como meio através do qual países estrangeiros, como a França, veiculam valores humanos supostamente universais. O fato, de existir (ou não) uma ameaça real é um assunto secundário. Pois, conforme as conclusões de uma pesquisa ${ }^{77}$ realizada em 2008, as

\footnotetext{
${ }^{76}$ Globalization and september 11. In: http://newleftreview.org/II/12/michael-mann-globalizationand-september-11. Acesso em: 12/02/2015.

${ }^{77}$ Dado calculado a partir do número de navios que circulam nos mares e dos atos piratas
} 
probabilidades de um navio ser atacado (independentemente do mar onde circula) ou de ser alvo de um ato pirata é de $0,012 \%$ ! E, se avaliarmos o risco de um navio ser atacado no período de dez anos (1995-2005) a percentagem sobe para 0,57\%. Infelizmente, a pesquisa não traz estatísticas relativas a cada zona marítima, o que dificulta a análise dos reais riscos que correm os petroleiros que circulam na região. Mesmo assim, juntando essas percentagens com os dados que constam na tabela anteriormente apresentada, pode-se sugerir que a pirataria não é um crime marítimo relevante, diante de outros atos perpetrados e questões urgentes a serem resolvidas no Golfo de Guiné, e na Nigéria em particular. Assim como os autores da pesquisa mencionada sugerem, considera-se que a pirataria é uma ameaça marginal.

Contudo, existe uma discrepância entre essa "ameaça marginal" e os discursos alarmistas construídos pelas vítimas internacionais dos atos piratas. De modo geral, a pirataria se tornou - entre 2008 e 2014 - um tema recorrente da agenda de segurança internacional. Vale frisar que a segurança internacional é um campo dinâmico de atuação que vem sendo ampliado à medida que o contexto político internacional se transforma. Em seus discursos, diversos representantes de instituições associaram rapidamente o tema da segurança - a pirataria sendo um elemento constitutivo deste - à ideia de ameaça em contexto internacional. Em outras palavras, o conceito de segurança passou a ser visto como conceito abrangente que solicitava participação de uma multiplicidade de atores como: ONU, CSNU, ONGs, Think tank, Estados, (etc.) para garantir sua eficiência e se tornar uma prioridade universal. É assim que, de maneira surpreendente, a ONU passou a se tornar um ator preponderante no âmbito da segurança regional. A ONU, encarregada dos assuntos de droga e crime (ONUDC), afirmaria que as instituições estatais e a figura do Estado são fracos e a tendência é ver a “instabilidade" aumentar, se os Estados não tomarem nenhuma providência.

A União Europeia (UE), enquanto outro ator relevante nesse cenário, também adota tal discurso. Nas duas últimas décadas, a UE assumiu sua função de ator de segurança, confirmando a preocupação dos Estados europeus em estabelecer, através de práticas discursivas, normas e programas de elaboração de

registrados (por ano). Cariou P., Meija M., Wolff F.C., 2009. Chap.7 Ship Piracy: Ship Type and Flag in Talley W.K. (eds), Maritime Safety, Security and Piracy,-- World Maritime University, Malmö. 
uma estratégia de defesa e segurança. Enquanto comunidade de segurança, a UE elegeu uma série de ameaças partilhadas pelos Estados membros. A imigração e o terrorismo são duas das ameaças mais citadas. A pirataria poderia ser incluída nesta lista.

Um dos elementos mais recorrentes dessa estratégia de segurança é o "uso da força" nas relações internacionais. Nas suas práticas discursivas, a UE propõe de maneira sistemática o uso da força para erradicar a pirataria da zona marítima em questão. $\mathrm{O}$ argumento se baseia em proposta de ordem (liberal) que possa garantir a paz no mundo. A França (como carro chefe) utiliza sua imagem de "país dos Direitos Humanos" para firmar sua posição em defesa dessa ordem. A ordem liberal (e pacífica) é definida a partir de valores (democracia, Direitos Humanos, liberdade, etc.) e de uma ideia subjetiva do que é "justo" ou "injusto".

Em suma, a retórica europeia se constrói em torno da garantia da segurança e consolidação da ordem liberal. Sublinhando que "estabilidade" e "instabilidade" são os novos elementos discursivos utilizados para justificar a atuação da UE e o recurso da força para preservar a segurança e a paz.

No entanto, por trás dessas ideias, discursos e estratégias, justamente a força militar e a legitimidade política da UE são os elementos decisivos quando um ator político opta pelo "uso da força". Os países da UE são convictos da necessidade de recorrer à força para garantir a segurança de seus navios. Os discursos pronunciados defendem o uso ampliado da força no mar. Contudo, tratase de uma questão paradoxal, pois o "uso da força" é considerado o último recurso nas relações internacionais, que deve ser acionado somente quando todas as ações diplomáticas já foram utilizadas.

No caso da pirataria, a UE anunciou, em janeiro de 2013, uma nova iniciativa chamada "The Critical Maritime Routes in the Gulf of Guinea Programme (CRIMGO)" para combater a pirataria no Golfo de Guiné. A proposta é apresentada da seguinte forma: "A new project which will boost security and the safety of maritime routes across seven African countries in the Gulf of Guinea."

A proposta ${ }^{78}$ é "ajudar" os governos nacionais africanos a "melhorarem" a segurança através da formação das suas guardas costeiras e o estabelecimento de uma rede de informação (supõe-se que se trate de uma espécie de INTERPOL) que

\footnotetext{
${ }^{78}$ Disponível no site: http://www.fei.gouv.fr/index.php/en/a-la-une/441-crimgo. Acesso em: 13/02/2015.
} 
inclui países e agências. Para tal iniciativa 4,5 milhões de euros foram desbloqueados e aplicados no projeto, considerado um instrumento para a estabilidade (IFS). O projeto conta com uma multiplicidade de instituições europeias envolvidas no controle policial do $\operatorname{mar}^{79}$. Andris Pielbags, responsável pelo desenvolvimento do programa, explica:

Without security, development can never properly reach the people it needs to. That's why our new project, which will help to boost transport security in Western Africa, is so crucial. By making the waters safe, we are helping to boost trade and growth and provide more opportunities to make a living, which these countries so desperately need. ${ }^{80}$

Com base nesse trecho de discurso, nota-se que "a segurança" consta aqui como valor universal. Segundo Andris, a segurança é uma noção universal e objetiva que não precisa ser definida. Outro aspecto a se destacar é a relação nítida que Andris faz entre segurança e desenvolvimento. Essa relação é validada no seguinte programa: The Instrument for Stability (IFS). A UE considera que o desenvolvimento é somente possível quando o espaço a ser desenvolvido é seguro. Portanto, existe por trás do seu programa, um único valor: a estabilidade da ordem liberal. Sem essa, não existe segurança, nem desenvolvimento. Nota-se que a palavra "desenvolvimento" - assim como a palavra segurança - é considerada universal. A presença europeia na região, através de projetos, forças militares e sua participação financeira na luta contra a pirataria, confirma que a mesma é um objeto securitizado e uma ameaça partilhada pela maioria dos Estados europeus. Lutar contra atos piratas é se afirmar como potência que procura enunciar normas na tentativa de controle das rotas marítimas.

A França é uma das potências europeias que procura exercer seu poder através do controle de diversos espaços marítimos. A questão do controle do mar é tão crucial que a França conta, desde 2008, com um Representante oficial de luta contra a pirataria ${ }^{81}$.

O país adota um discurso de pioneirismo em matéria de detecção de

\footnotetext{
${ }^{79}$ O projeto inclui: "France Expertise International", a "Direction de la Coopération de Sécurité et de Défense", a "Direção-Geral da Política do Mar", a "Fundación Internacional y para lberoamérica de Administración y Políticas Públicas", a "Foreign and Commonwealth Office", a "Satakunta University of Applied Sciences", a "International Maritime Safety Security Environment Academy", e a "Szczecin Maritime University".

${ }^{80}$ Idem.

${ }^{81}$ Chantal Poiret foi nomeada para esse cargo em outubro de 2008. Em 2014, Véronique RogerLacan, foi escolhida como Représentante spéciale pour la lutte contre la piraterie maritime,
} 
ameaças em questão de segurança marítima e lembra, através de práticas discursivas, que sempre contribuiu nas operações da UE de luta contra a pirataria (principalmente na Somália: EUNAVFOR Atalanta, EUCAP, NESTOR, EUTM) e da NATO (Ocean Shield) ${ }^{\mathbf{8 2}}$.

O governo francês destaca seu papel estratégico e preconiza uma abordagem global da segurança no mar e na terra. Considera ainda que é o único ator a propor essa perspectiva (o Reino Unido é considerado como ator que foca em ações militares) e considera que sua atuação permitiu obter "resultados que abrem o caminho para uma estabilização da situação no mar" ${ }^{83}$.

Depois de sua experiência na Somália, a França assumiu parte das operações de apoio à securitização nos espaços marítimos do Golfo de Guiné. Além da "missão Corymbe", a França atua no Golfo de Guiné através do Programme de Renforcement des Capacités Africaines de Maintien de la Paix en Afrique (RECAMP) e l'Appui à la réforme de la Sécurité Maritime dans le Golfe de Guinée (ASECMAR). Esse último projeto pretende melhorar "as capacidades da administração interna da segurança e coordenação regional nas questões marítimas". No mapa a seguir, consta um recapitulativo das missões em curso e das ameaças identificadas.

\footnotetext{
${ }^{82}$ Para mais informações consultar o site: http://rpdefense.over-blog.com/tag/piraterie/

${ }^{83} \mathrm{http} / / /$ www.diplomatie.gouv.fr/fr/IMG/pdf/inauguration8septembre_cle0ef887.pdf
} 


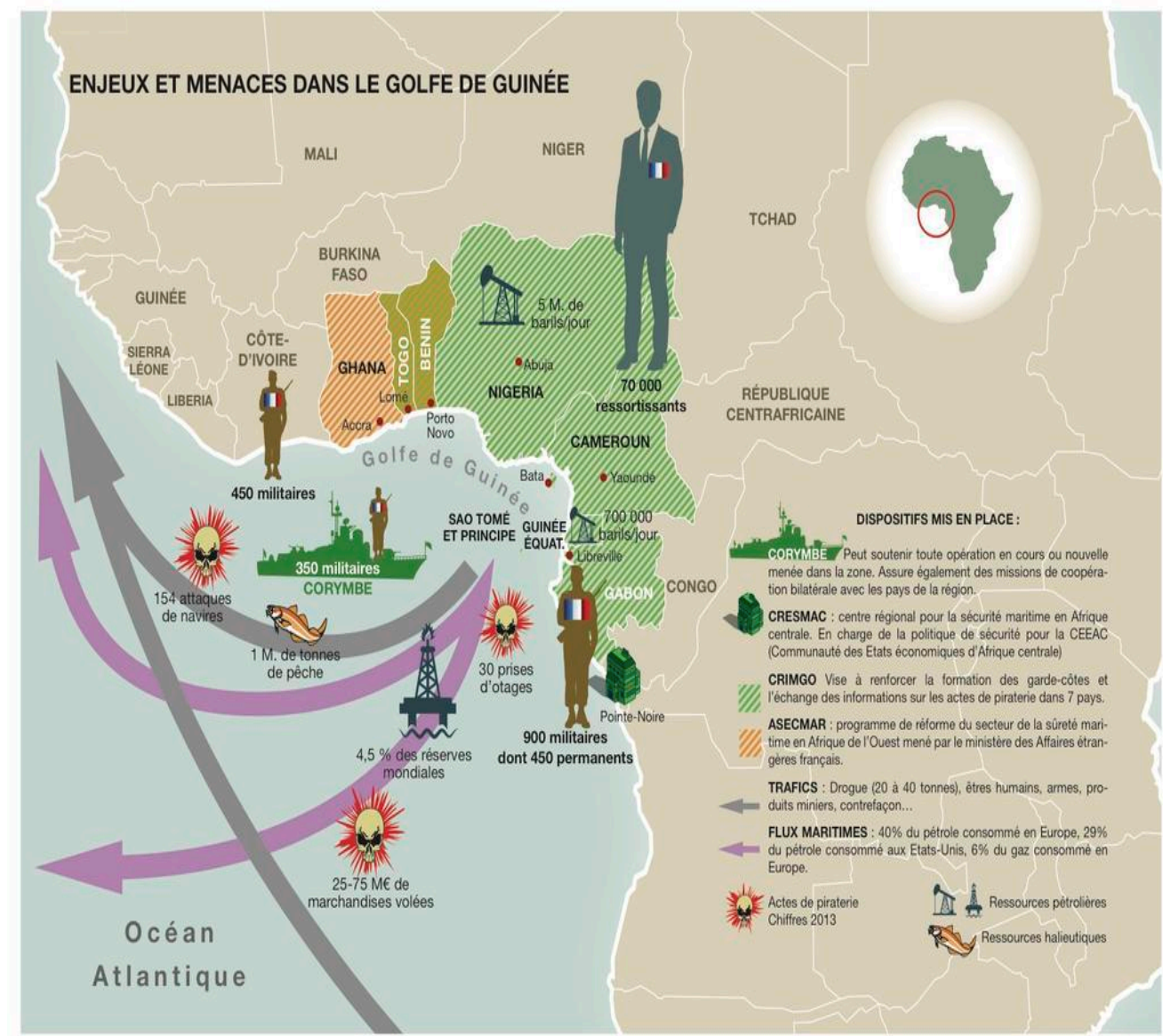

Figura 7: Mapa das missões e ameaças identificadas Fonte: http://rpdefense.over-blog.com/tag/piraterie/

Nota-se que em suas intervenções, a França conta com uma multiplicidade de atores que recolhem informações e constroem práticas discursivas. A mesma situação ocorre, com a participação de diversos ministérios, para tomar decisões. Vale lembrar que o país possuía colônias na região e tentou, depois das independências, manter um controle político e econômico na África do Oeste. A intervenção de outros atores internacionais como a China e os Estados Unidos levou à perda de legitimidade e autoridade da França na região. O país ofereceu seu apoio financeiro ${ }^{84}$, logístico e em inteligência militar com envio de conselheiros militares. Além de presença militar na região chamada Corymbe onde, desde os anos noventa, garante a presença física no local com intuito de preservar os interesses econômicos franceses. Mas nas práticas discursivas, o governo francês, através das palavras ${ }^{85}$ de Véronique Roger-Lacan insiste em

\footnotetext{
${ }^{84} \mathrm{Em}$ 2011, através de um financiamento do 'Fonds de Solidarité Prioritaire' a França assinou um projeto de apoio durante três anos ao Benim, Togo e Gana. O projeto financia a formação de civis e forças armadas e a instauração de um programa de estratégia nacional de segurança marítima.

${ }^{85} \mathrm{http}: / /$ www.diplomatie.gouv.fr/fr/IMG/pdf/inauguration8septembre_cle0ef887.pdf
} 
defender sua atuação em nome dos "principais prejudicados", que são os cidadãos do Golfo de Guiné.

É incontestável que a França privilegia o emprego de sua força naval de guerra no seu programa de ações executadas no mar, tendo o Estado como referente que defende seus interesses políticos e econômicos. O país tenta manter uma presença política na região alegando os laços históricos existentes entre as ex-colônias africanas e a sua antiga metrópole. No entanto, esse discurso retrógrado não convence mais os países africanos independentes, que privilegiam relações internacionais com outros atores - como Estados Unidos. Dada a instauração de livre concorrência após o fim da Guerra fria, Washington se fortalece com as lacunas na política africana da França. A perspectiva estadunidense visa a contestar a tutela política francesa - ainda existente - para com suas ex-colônias. A administração norte-americana, em contraste às propostas de Paris, promete a promoção da democracia, a inserção das economias africanas na economia mundial, a liberalização econômica. Em suma, a abordagem norte-americana visa seduzir os países africanos que criticam a política africana da França.

Obviamente, a política norte-americana - através do United States Africa Command (AFRICOM), formalmente criado em 2008, e outras operações possui uma forte dimensão geoestratégica e dispõe de objetivos não oficiais que explicam sua presença maciça na região do Golfo de Guiné, conforme veremos mais adiante.

\section{2}

Breve apresentação da política de segurança norte-americana para a África centro-ocidental

O objetivo oficial do programa do Comando dos EUA para África (AFRICOM), anunciado pelos Estados Unidos é: 
Conseguir um nível contínuo e constante de engajamento na segurança com os nossos parceiros africanos, orientado para programas de prevenção do conflito e promoção do diálogo contínuo e o desenvolvimento. Este engajamento é definido pelo termo "segurança activa" e inclui programas militares para militares e actividades patrocinadas por militares que promovem um ambiente africano estável e seguro em apoio à política externa dos $\mathrm{EUA}^{86}$.

A administração norte-americana alega que o Comando para África dedica-se à prevenção do conflito e da guerra, e não ao combate. Assim, o Comando dos EUA para África se propõe a estabelecer parcerias com os Estados africanos e ajudá-los a construir a segurança regional do Golfo de Guiné. A luta contra a pirataria se insere no campo da segurança regional.

Assim como para a UE, as noções de segurança e estabilidade são associadas, ambas representam condições sine qua non para garantir o desenvolvimento econômico da região. Observa-se o uso da noção de "segurança" associada a um novo termo: "segurança ativa", que se baseia, conforme a citação acima apresentada, na prevenção, no diálogo e nas parcerias estabelecidas com a África na formação militar. O discurso oficial norte-americano enfatiza que o objetivo da "segurança ativa" consiste em: "permitir o trabalho de africanos para marginalizar os inimigos da paz, prevenir o conflito, promover o crescimento de governos fortes e justos e instituições legítimas e apoiar o desenvolvimento das sociedades civis". ${ }^{87}$

Os EUA confirmaram a institucionalização da militarização do Comando, consolidando sua linha de atuação no combate ao terrorismo global. Em site oficial $^{88}$, AFRICOM é apresentado como o Comando que: “(...) assumirá responsabilidade administrativa pelo apoio militar dos EUA à política do governo norte-americano em África, incluindo relações entre militares com 53 países africanos".

Por trás do estabelecimento dessas novas parcerias, vale destacar certas informações que ajudam a entender as estratégias americanas que justificam sua presença no Golfo de Guiné. Em 2002, o país produzia 7,6 milhões de barris de petróleo por dia, enquanto seu consumo interno, no mesmo ano, foi avaliado a 19,7 milhões de barris por dia. Isso significa que os Estados Unidos não conseguiam

\footnotetext{
${ }^{86}$ Informações disponíveis em: http://portuguese.maputo.usembassy.gov/africom2.htmlNotícias, acesso: 07/ 01/2015.

${ }^{87}$ Ibidem. P.1.

${ }^{88}$ Para mais amplas informações ver: http://portuguese.maputo.usembassy.gov/africom2.html. Acesso: dia 22/01/2014.
} 
produzir o suficiente para garantir seu consumo interno e precisavam importar 12,1 milhões de barris por dia $-60 \%$ do consumo total em petróleo bruto ${ }^{89}$. O país passou a enxergar a África como fornecedor potencial de cerca de $25 \%$ do seu consumo, evitando assim uma dependência maciça do país com a OPEP e o oriente médio.

Os objetivos militares ${ }^{90}$ dessa missão são: combater Al-Qaeda e qualquer outra organização terrorista na região; reforçar as capacidades militares e democráticas dos principais países africanos; ajudar os países africanos, parceiros dos Estados Unidos, para que esses sejam capazes de participar, de maneira eficiente, das operações de paz na região e em contexto internacional e ajudá-los a lutar contra as violações dos Direitos Humanos.

A palavra terrorista deve ser sublinhada aqui. Já que ela representa, ao nosso entender, o fundamento real da presença americana no Golfo de Guiné. Ndlovu-Gatscheni afirma:

\begin{abstract}
At the global level the present era is also characterized by intensification of 'securitization' of Africa that is, defining Africa as a security risk and a zone of conflict. This discourse came into the center of international politics following 9/11 attacks on the twin towers in the United State of America. Within this discourse the African continent is an abode of weak, failed and collapsed states that are in turn abodes of terrorists (Ndlovu-Gatsheni 2010, p. 96).
\end{abstract}

Muito embora o terrorismo e a pirataria não se confundam, essas ameaças são, por vezes, associadas. Como o indica Ndlovu-Gatsheni, os acontecimentos do 11 de setembro são a razão que explica essa associação e o fato do continente africano ser considerado como palco propício para manifestações e atos terroristas. É a partir deste marco que os Estados Unidos começaram a desenvolver mecanismos e tecnologias de controle mais robustos para inibir o terrorismo e a pirataria em África, e mais especificamente no Golfo de Guiné principal provedor de petróleo do país.

Os argumentos utilizados para defender a guerra global ao terrorismo e seus pressupostos podem também ser aplicados ao estudo de caso da pirataria no Golfo de Guiné e, de forma geral, constitui um ponto de partida para pensar as

\footnotetext{
${ }^{89}$ Para mais informações, consultar: http://www.diploweb.com/AFRICOM-Le-commandementmilitaire.html "La sécurité énergétique américaine ou la défense de l'american way of life?". Acesso, dia 07/01/2015.

${ }^{90}$ Ibid.
} 
práticas de "segurança ativa" dos EUA na África. O terrorismo e a pirataria foram também objetivos securitizados pelos EUA. Diversas instituições americanas avaliaram que grupos terroristas estariam ameaçando a segurança regional (terrestre e marítima) africana e, consequentemente, a segurança internacional, ou mais especificamente, dos países ocidentais. A securitização destes espaços se inscreve também no programa AFRICOM.

Se AFRICOM representa o programa guarda-chuva dos EUA, diversas operações mais específicas ocorrem constantemente no Golfo de Guiné e são ligadas à prevenção das ameaças na região. O Obangame Express é uma dessas operações e tem como objetivo:

\begin{abstract}
Capacitar os países africanos para prover a segurança marítima da área do Golfo da Guiné contra ações de pirataria, tráfico de drogas e armas, sequestro, pesca ilegal e outros atos ilícitos praticados na região. Para isso, são realizados exercícios de operações de interdição marítima, técnicas de abordagem e treinamentos médicos e meteorológicos para testar e avaliar a interoperabilidade regional, a relação multinacional de Comando e Controle e a proficiência marinheira dos países africanos com seus parceiros regionais do Golfo da Guiné, em conjunto com os países estrangeiros participantes ${ }^{91}$.
\end{abstract}

A operação se inscreve na linha de atuação padrão dos EUA, e de outros atores internacionais, em matéria de segurança. Na edição 2014, por exemplo, países como Alemanha, Bélgica, Benim, Brasil, Espanha, EUA, Portugal, e Turquia participaram juntos com seus parceiros africanos: Angola, Camarões, Congo, Costa do Marfim, Gabão, Gana, Guiné Equatorial, Nigéria, São Tomé e Príncipe e Togo.

Conforme Ndoutoume Ngome Jonathan (2012 p.179) aponta de maneira pertinente, a noção de segurança dos espaços marítimos não é determinista. Em outras palavras, são os homens e suas estratégias, representantes ou não dos Estados, que fazem a segurança, constroem sistemas de proteção, criam ameaças. As políticas de segurança ou de defesa visando a luta contra o terrorismo e a pirataria se baseiam em elementos subjetivos que determinam o conceito de segurança. O desafio de segurança das áreas marítimas é multifacetado e depende basicamente das formas tecnológicas e vontade política. De fato, a tecnologia de

\footnotetext{
${ }^{91}$ Informações disponíveis em: http://www.defesanet.com.br/naval/noticia/15630/NPaOc$\% \mathrm{E} 2 \% 80 \% 9 \mathrm{CAPA} \% \mathrm{E} 2 \% 80 \% 9 \mathrm{D}$-participa-do- $\% \mathrm{E} 2 \% 80 \% 9$ CObangame-Express2014\%E2\%80\%9D/. Acesso em: 16/02/2015.
} 
ponta e a vontade política americanas são elementos que contam a seu favor e favorecem seu autoritarismo na guerra total contra o terrorismo.

Nesse campo, Buzan (2006) afirma que EUA se autoproclamou líder em termos de combate ao terrorismo e, através do seu auxílio a seus parceiros africanos, conseguiu consequentemente impor sua perspectiva da "segurança", formando equipes militares a adotarem suas medidas (subjetivas) de prevenção e combate.

No terrorismo e na pirataria, regiões avaliadas como ameaças contam com a presença marcante de grupos islâmicos radicais, regimes estatais não democráticos, e Estados considerados fracos, como é possível constatar na citação apresentada. Em outros termos, a desordem; a ameaça à instauração de uma ordem liberal; a insegurança e a instabilidade são elementos constitutivos do álibi norte-americano para aumentar e justificar sua presença militar no Golfo de Guiné. Dentro da perspectiva norte-americana, as ameaça são claras. Cita-se, entre outras: o tráfico de seres humanos e migração ilegal; o tráfico de drogas (principalmente cocaína consumida pelos EUA e que passa pela África do Oeste); a venda ilegal do petróleo na Nigéria (avaliada em três milhões de dólares por dia, conforme dado apresentado pela Human Rights Watch); e o aumento da pirataria global por conta do registro de ataques que se multiplicaram no continente.

Assistimos então a um paradoxo, levantado por Estrada e Mattos (de) (2013), no qual os EUA são considerados como país que promove valores liberais e preconiza o estabelecimento de um regime democrático para a aplicação desses valores e, ao mesmo tempo, mobiliza todo um aparato militarizado na região, assumindo seu papel de potência normativa que enuncia normas e princípios de segurança. Diversos autores (Toby \& Popovic 2007; Estrada e Mattos (de) 2013) alertam que a presença militar estadunidense tem como consequência o fortalecimento dos regimes autoritários em vigor e dos grupos radicais islâmicos paralelamente. No caso dos atos piratas, conclui-se que os piratas não são intimidados pela presença militar norte-americana e mantêm sua linha de atuação.

Considerando esses elementos, avalia-se que a securitização da pirataria no Golfo de Guiné é um processo político construído por atores políticos internacionais (UE e EUA), para aforar as suas percepções de ameaça. Cabe frisar que este processo político se insere na dinâmica "Repressão-RadicalizaçãoSecuritização" sugerida por Estrada e Mattos (de) (2013). Com base na sugestão 
destes autores, pode-se avançar a hipótese de que tais atores políticos internacionais são responsáveis pela desestabilização crônica da segurança africana, pelo risco de extraversão da estratégia de segurança regional e pela persistência dos atos piratas na região.

\section{3 \\ A governança na luta contra a pirataria: reflexões sobre o regionalismo africano}

Em entrevista ${ }^{92}$ concedida por Jean-Yves Le Drian, o ministro da defesa da França afirmou que Paris auxiliava constantemente os países africanos na elaboração de uma estratégia comum de segurança. Ao mesmo tempo, em mensagem proferida durante o Fórum Internacional de Dacar sobre paz e segurança em África em dezembro de 2014, o ministro demonstrou "impaciência" ao afirmar que "era mais do que hora dos africanos assumirem o comando das operações e reunir os meios disponíveis para melhorar sua defesa". Criticou ainda, de maneira indireta, a "lentidão" da construção da arquitetura regional de defesa do espaço marítimo do Golfo de Guiné.

O ministro ainda apontou para a relevância do regionalismo na criação de uma estratégia coletiva de defesa, já que ele considera que uma gestão nacional das questões de segurança é uma ilusão, posto que "o terrorismo não tem fronteiras e se amplia por conta da fragilidade dos espaços para além das fronteiras" ${ }^{93}$. A África do Oeste confirma ser, através dessa questão, um Complexo Regional de Segurança e os Estados africanos reconhecem a pertinência de adoção de estratégias coletivas para resolver problemas e ameaças comuns. No entanto, se existe um consenso sobre a necessidade de uma segurança coletiva, os Estados africanos ainda não resolveram seus problemas de fronteiras (principalmente marítimas) com seus vizinhos. Bathélémy Blédé, pesquisador em segurança marítima no Institute for strategic studies (ISS) de Dacar, indaga como Gana e Costa do Marfim (por exemplo) podem organizar patrulhas conjuntas se a delimitação de suas fronteiras marítimas não foi finalizada?

\footnotetext{
${ }^{92}$ Entrevista concedida por Jean-Yves Le Drian a Jean Guisnel Défense ouverte - Le Point.fr. disponível em: http://www.lepoint.fr/editos-du-point/jean-guisnel/securite-en-afrique-le-forum-dedakar-expose-plus-de-problemes-que-de-solutions-17-12-2014-1890322_53.php. Acesso dia $03 / 02 / 2015$.

${ }^{93}$ Ibid.
} 
O Estado francês não deixa de ser incisivo quando o assunto é a dificuldade de organização de uma resposta regional e acordos bilaterais na luta contra a pirataria. Assim, Véronique Roger-Lacan ironiza: "Pendant que nous signons des documents, les pirates, eux, continuent d'agir" (2013, p.2). O que pode ser considerado como crítica à multiplicação de acordos multilaterais e bilaterais, bem como à burocracia existente em termos de jurisdição e no julgamento dos piratas e, ainda, à falta de empenho quanto a necessidade de implementação de uma "segurança ativa" na região. O CSNU critica também a postura africana no Golfo de Guiné, a falta de consenso e estratégia coletiva para garantir a segurança marítima da região.

Vale lembrar que as Resoluções 2018 e 2039 do CSNU preconizavam uma arquitetura regional de grande amplitude para controlar os atos piratas do Golfo de Guiné. Com essas duas Resoluções, o CSNU se mostrou convencido da pertinência de uma abordagem regional para enfrentar as ameaças marítimas e energéticas, garantir o andamento do comércio internacional marítimo na região, investir na guerra mundial contra o terrorismo, o tráfico de drogas e armas e a imigração ilegal. O recurso ao uso da força como solução eficaz tem sido mencionado ou sugerido para responder as ansiedades dos atores políticos internacionais e constitui uma resposta "rápida", em oposição à somente "assinar documentos", como retrucou a representante francesa na luta contra a pirataria. No entanto, essa lista de prioridades a serem tratadas na estratégia de segurança regional não parece corresponder às realidades e as prioridades dos países - e de suas populações - que possuem litoral no Golfo de Guiné.

As prioridades dos Estados africanos da região podem divergir ou eventualmente convergir com as prioridades do CSNU e das potências extra regionais. Mas, o que é evidente é que a lista de prioridades do CSNU não são as mesmas do que as das comunidades e populações do Golfo de Guiné. A noção de segurança definida pela ONU diverge também da definição do mesmo conceito por parte dessas mesmas comunidades. Para exemplificar essa ideia, julga-se oportuno citar Saro-Wiwa para evidenciar a perspectiva Ogoni da noção de segurança: 
We in Dere, a community in Ogoni today are facing a situation which can only be compared to that of a civil war....the ocean of crude oil had emerged, moving swiftly like a great flood, successfully swallowing up anything that comes its way; crops, animals, etc....There is no pipe borne water and yet the streams, the only source of drinking water is coated with oil. The air is filled with crude and smells only of crude oil. We are thus faced with a situation where we have no food to eat, no water to drink and no air to breathe (Saro-Wiwa, 1995, p.14).

A noção de segurança para os Ogoni poderia ser a garantia de acesso à água potável e ar não poluído? O contraste entre visões sobre a noção de segurança em função do ator político entrevistado é abismal. Nota-se ainda a desconexão entre as prioridades estabelecidas pelo CSNU, as de um Estado africano como Nigéria e as exigidas por parte de diversas comunidades do Estado do Delta. Em outras palavras: por um lado, temos as preocupações da Comunidade Internacional, que se baseiam na segurança do transporte marítimo, tendo o CSNU como porta-voz. E, por outro lado, múltiplas outras preocupações sendo priorizadas pelo Estado e atores não-estatais da região. O Estado pode também ter problemas de segurança que são muitas vezes relacionados às questões que ocorrem no espaço terrestre, como é o caso da Nigéria. Posto isso, é preciso mencionar as pressões internacionais exercitadas por essa Comunidade Internacional para que suas prioridades sejam tratadas na agenda dessa estratégia regional de segurança marítima. Os atores políticos internacionais apoiam a iniciativa regional desde que essa garanta a defesa de seus interesses.

Demonstrou-se ao longo dos capítulos que, a interferência dos atores internacionais para defender seus interesses na questão da segurança marítima é estimável. Em outras palavras, as potências e instituições estrangeiras ${ }^{94} \mathrm{se}$ apresentam como atores imprescindíveis para resolver a situação no Golfo de Guiné e participar da construção e formação de um poder regional para atuar contra a pirataria. No entanto, a atuação desses atores internacionais pode, em certas situações, resultar em uma violação da soberania dos Estados da região africana - que possuem recursos financeiros e tecnológicos limitados - em nome dos seus interesses políticos e econômicos. A securitização da pirataria consta como estratégia que corresponde à instauração de valores e regimes de verdade por parte dos atores políticos internacionais, que determinam as ameaças.

\footnotetext{
${ }^{94}$ Vircoulon afirma que países como o Japão contribuíram em termos financeiros no Fundo para a segurança marítima da África do Oeste e do Centro sob a administração da OMI.
} 
Viu-se que, após a Resolução de 2018, os Estados do Golfo de Guiné começaram a estabelecer acordos bilaterais com seus vizinhos. A Nigéria e o Benim vão assinar o primeiro acordo de cooperação bilateral da região no campo de segurança internacional. Esse acordo militar prevê uma cooperação entre os dois países vizinhos para mobilizar uma patrulha conjunta encarregada de circular nas suas zonas marítimas. A missão foi mantida durante seis meses e permitiu lidar com as patrulhas com base nas jurisdições dos dois países.

Apelar para uma iniciativa regional é contar com a CEEAC e CEDEAO, as duas instituições regionais de referência. No entanto, já foi possível notar diferenças de atuação por parte dessas duas instituições. A CEEAC parece ter mais prática nestas questões e já desenvolveu um programa de segurança marítima, o que falta ainda na CEDEAO (Ukeje \& Mvomo Ela, 2010, p.29-30). Existem, obviamente, limitações ao desenvolvimento dessa estratégia de segurança. As duas instituições possuem, por exemplo, uma capacidade militar, financeira e logística restrita para responder aos desafios da segurança marítima. Com isso, as duas instituições dependem da assistência da Comunidade Internacional, que se outorga o direito de ditar normas dessa estratégia marítima regional. Se a CEEAC estabeleceu um programa de segurança desde 2009, os Estados membros da CEDEAO só começaram a debater essa questão em 2010. É quando os atos piratas começaram a se expandir além das águas territoriais nigerianas que os membros da CEDEAO constataram a pertinência da elaboração de um programa regional de atuação.

A estratégia marítima continental - Estratégia Marítima Integrada da África (SMIA), criada em 2009 - se inscreve no já citado projeto de estratégia da África 2050 (MIA 2050) e visa auxiliar as forças regionais em sua empreitada. Apesar desse apoio, a iniciativa tem gerado ceticismo e críticas.

$\mathrm{O}$ pesquisador Thierry Vircoulon, vinculado ao Internacional Crisis Group, nos alerta sobre os obstáculos relativos à implementação de uma cooperação regional eficaz ${ }^{95}$. O autor menciona primeiramente o fato de que a luta contra pirataria exige tempo e se desenvolve no longo prazo. Ele ainda considera que a CGG é uma "concha vazia" e que a multiplicidade dos atores no

\footnotetext{
95 http://blog.crisisgroup.org/africa/2014/09/04/golfe-de-guinee-la-regionalisation-de-la-securitemaritime-est-elle-la-solution-contre-la-piraterie/
} 
cenário regional implica ainda uma fragmentação das responsabilidades, da coordenação das duas associações de Estados.

Thierry Vircoulon (2014) analisa também a questão da liderança do poder regional. Entre as disputas sobre fronteiras marítimas e/ou terrestres (caso de Gana e Costa do Marfim; Gabão e Guiné Equatorial, São Tomé e Príncipe e Nigéria, etc.) e questionamentos sobre a liderança assumida pela Nigéria, o poder regional se constrói ao longo prazo e não representa a unanimidade. Outros líderships são mencionados por Awoumou (2005, p.6), com a possível consagração do CEEAC e Camarões e Chade como líderes ou a eventual consolidação da CGG com a liderança da Nigéria - Angola - Camarões.

Se o regionalismo aprece o modelo de segurança viável para o Golfo da Guiné, muitas questões apresentadas precisam ainda ser resolvidas. Vircoulon prevê que o fim do apoio financeiro da Comunidade Internacional levaria as políticas de apoio a "um campeão regional" e a ajudas bilaterais entre um país africano da região e um país estrangeiro. Essa previsão é pertinente e aponta para o risco de exacerbação da competição entre países do Golfo de Guiné para solicitar material de defesa dos seus parceiros estrangeiros. Ou seja, a dependência financeira e material seria mantida, porém com outras modalidades.

Alguns autores como Augé (2009) mencionaram também a necessidade de incluir o espaço terrestre na estratégia regional de segurança. Sem tratar dos problemas que ocorrem nesse espaço - cita-se aqui o mercado local e regional de contrabanda de petróleo - não é possível lutar contra a pirataria no alto mar, avalia o autor.

As redes globalizadas, as ameaças e problemas partilhados e as discussões em torno do conceito de segurança obrigam os Estados nacionais a abrirem mão de uma discussão local, nacional. Ou melhor, a considerar que a discussão local e nacional deve ser inserida em debate mais amplo. Com efeito, as instituições regionais e os Estados africanos passam a aceitar que assuntos internos sejam analisados por atores internacionais, em nome da globalização do debate sobre ameaças e segurança marítima local. Destaca-se, ainda, a dependência quase exclusiva desses Estados e instituições em relação ao apoio logístico, material e militar oferecidos pelos atores políticos internacionais. Citou-se o exemplo dos Estados Unidos e da França, que se caracterizam por ações intervencionistas. Em 
suma, a segurança e os espaços securitizados são moldados pelos Estados regionais e pelos atores internacionais ${ }^{96}$.

Maurino Évora explica a problemática da integração regional e seu difícil desenvolvimento pela ameaça que representa para a soberania dos Estados nacionais:

A esfera da política securitária é, em muitas formas, o último bastião a partir do qual os Estados fracos reforçam a sua soberania. Só se compreende o facto de os Estados membros da CEDEAO não quererem abrir mão de parte da sua soberania política. Todavia, é preciso termos presente que a transferência da soberania, por si só, não resolve a questão. Esse processo deverá ser acompanhado de soluções políticas eficientes. As raízes das crises securitárias em África Ocidental possuem uma natureza eminentemente doméstica, assim como os principais instrumentos para lhes fazer face. Por isso, a adopção de uma estratégia de segurança comum é susceptível de fomentar e pressionar os Estados membros a procurarem em conjunto as soluções para os seus problemas ${ }^{97}$.

Embora não compartilhe-se a ideia de Estado fraco, o receio da perda de soberania se torna viável para explicar as dificuldades encontradas em estabelecer um consenso no leadership da região e desenvolver uma integração regional que possa auxiliar os Estados na resolução de seus problemas internos. Apesar de criticada, a integração regional acaba sendo a única estratégia viável para solucionar problemas partilhados pelos Estados nacionais da região. Pois, facilita a constituição de conjuntos de países de uma mesma esfera geográfica que procuram unificar suas estruturas e harmonizar suas instituições.

\footnotetext{
${ }^{96}$ Vale mencionar a existência de outras relações internacionais, como a iniciativa multilateral de cooperação para a segurança marítima e o desenvolvimento do Atlântico sul, proposta de cooperação sul/sul entre os países da América do Sul e os da costa da África do oeste.

97 Évora, M. (2011). Que Regionalismo Securitário para a África Ocidental? ISEG (CESA): in Seminário sobre Ciências Sociais e Desenvolvimento em África. Disponível em: http://pascal.iseg.utl.pt/ cesa/files/Doc_trabalho/18-MaurinoEvora.pdf. Acesso dia 09/02/2015.
} 


\section{5. \\ CONSIDERAÇÕES FINAIS}

O principal objetivo dessa dissertação foi propor uma análise crítica sobre a erradicação dos atos piratas que ocorrem no Golfo da Guiné. Na escolha de um enquadramento teórico, julgou-se oportuno basear-se nas Teorias dos Complexos Regionais de Segurança, partindo da premissa de que há um compartilhamento de percepções intersubjetivas sobre a pirataria - considerada como uma ameaça existencial e um objeto a ser securitizado - entre vários atores (regionais e internacionais). Observou-se que a securitização da pirataria, no entanto, corresponde a uma política de segurança extremamente subjetiva e que contempla os interesses dos investidores estrangeiros no Golfo de Guiné e os governos dos Estados locais. A aplicação desta prática de segurança na região marítima estudada leva ainda à despolitização de questões cruciais, como por exemplo, a própria atuação política de certos "piratas" e, as consequências relativas à corrida pelo petróleo no Golfo (por sinal, uma das principais implicações dos atos piratas e da indignação popular local).

Aplicando o conceito de Complexo Regional de Segurança (CRS) ao estudo de caso, pressupôs-se que a Comissão do Golfo de Guiné poderia ser analisada como um Subcomplexo Regional de Segurança. Argumentou-se que essa Comissão poderia ser definida como um SubCRS diante de sua configuração e atuação como ator regional, sua implicação na construção de uma arquitetura de segurança regional/local e o fato de representar uma instituição que auxilia os seus Estados membros a criar respostas regionais para ameaças e problemas comuns. $\mathrm{O}$ movimento securitizador da pirataria no Golfo da Guiné, as limitações da CGG na luta contra a pirataria no seu espaço marítimo e os motivos da constante ingerência de atores políticos internacionais na dinâmica de segurança regional também foram apresentados.

A ingerência dos atores extrarregionais nos assuntos políticos regionais, como vimos, se deve em boa medida ao poder de compra do petróleo africano, e as capacidades financeira, logística e militar dos países estrangeiros. A partir disto, analisou-se a participação desses atores internacionais na erradicação da pirataria e o risco de "extraversão" da política regional de segurança marítima. Tratou-se também de sinalizar a heterogeneidade dos crimes marítimos no Golfo 
da Guiné, sinalizando o fato de que a maioria dos crimes que ocorrem na região, de acordo com a CNUDM de 1982, sequer correspondem ao crime internacional de pirataria definida no seu artigo 101. A partir disto, procurou-se explicar que esse fenômeno se insere também no contexto geopolítico contemporâneo e provoca situações "novas". Uma delas é a proliferação das Companhias de Segurança Marítima Privada que surgem para oferecer escolta às embarcações comerciais privadas. Essas, como tratou-se de explicar, são poucos eficientes e exacerbam o quadro de violência local.

Em seguida, propôs-se repensar a pirataria no Golfo da Guiné a partir de perspectivas diferentes e que permitissem um entendimento mais compreensivo desta atividade no espaço marítimo estudado. Visando mais esclarecimentos sobre quem são os piratas, constatou-se que as suas perspectivas e discursos são demasiadamente pouco analisados. É relevante, em pesquisa que trata dessa temática, interrogar outras fontes e perspectivas, como as existentes nas ciências sociais, para entender que a noção de pirataria é subjetiva e ressignificada em função dos interesses de atores políticos, das vítimas de atos piratas e instituições que se autoproclamam guardiões da segurança marítima.

Procedendo à contextualização geográfica e política regional, validou-se o pressuposto segundo a qual é possível associar a corrida pelo petróleo local, a insatisfação popular e local relativa à má gestão dos recursos do petróleo e os atos piratas perpetrados na região. Os piratas se utilizam da insatisfação e reivindicações das comunidades, tanto quanto das críticas às consequências ligadas à exploração/comércio e poluição do petróleo bruto, para argumentar a favor de sua atuação criminosa. Isso leva alguns autores a considerar que existem dois tipos de pirataria no Golfo de Guiné: a pirataria baseada em interesses financeiros e a pirataria baseada em motivações políticas e financeiras.

Procurou-se ainda mostrar que as reivindicações de grupos militantes como o MEND, sua atuação política e interesseira e as respostas dadas pelo governo federal nigeriano são elementos que contribuem para a perpetuação dos conflitos existentes no Delta do Níger, desde a guerra do Biafra. O MEND, como viu-se, é associado aos grupos piratas pela comunidade regional e internacional por apresentar como um dos seus atos o exercício do controle total dos recursos petrolíferos locais. No contexto atual, representa um poder político alternativo ao Estado nacional nigeriano. 
Notou-se também que o governo nigeriano, por seu turno, encontra-se muito fragilizado, já que sua economia se baseia na exploração e exportação de recursos ligados ao petróleo e, ao mesmo tempo, enfrenta uma situação social caótica e complexa, com muitas denúncias de má gestão dos recursos petrolíferos e de uso excessivo da violência militar. Avaliou-se ainda, no segundo capítulo, que apesar das diferentes tentativas dos governos sucessivos em remediar a situação, principalmente no seu diálogo com os piratas (a partir do uso da força com a JTF- ou através de negociações) não se observa a aplicação de soluções eficazes. Os atos repressivos contra os militantes dos diversos grupos do Delta e as populações locais (diga-se de passagem, os piratas) alcançou como resultado o aumento do descontentamento dos cidadãos, a confirmação das acusações (locais e internacionais) de corrupção e de mercado paralelo de venda do petróleo sustentado por membros de Estado, o rearmamento dos grupos militantes e o aumento da repressão por parte do governo nigeriano. Chegou-se a conclusão de que a noção de interesses, de jogo de poder, de luta pelo monopólio da violência e elaboração de normas para construir um programa de segurança regional são, por conseguinte, elementos constitutivos da dinâmica da luta contra a pirataria.

No terceiro capítulo, buscou-se trazer um conjunto de informações que permitissem dar sequência às noções sobre o movimento e ato securitizador da pirataria na região estudada. Tratou-se de expor algumas soluções apresentados pelos agentes securitizadores em três níveis de análise, nesta respectiva ordem: local, internacional e regional. Apresentou-se primeiramente a atuação do governo nigeriano, em seguida a atuação da União Europeia (França) e os Estados Unidos e, por fim, algumas dinâmicas entre atores políticos, notadamente a CGG, CEDEAO e a CEEAC, na tentativa de manutenção da segurança regional.

Um dos aspectos mais curiosos destas reflexões foi perceber que na atribuição de novos significados para a noção de segurança, os atores internacionais se tornaram imprescindíveis, notadamente a França e os Estados Unidos. Por serem os maiores implicados na exploração do petróleo no Golfo da Guiné e terem maior capacidade de construir discursos e prioridades de segurança, os Estados locais praticamente delegaram as responsabilidades para estes dois atores políticos para, em projetos distintos, elaborarem uma arquitetura de segurança regional. 
Buscou-se evidenciar, no entanto, que as especificidades securitárias no Golfo da Guiné, em especial no Delta do Níger, devem ser inseridas na pauta securitária regional dando abrangência às ameaças às populações. Procurou-se mostrar que a noção de segurança é polissêmica, globalizada e interdependente e os líderes africanos não podem desconsiderar os impactos que uma política de segurança regional elaborada por atores internacionais podem ter nas relações sociais e na dimensão ética e política.

Não obstante às críticas, a integração regional pareceu a melhor solução para enfrentar os problemas políticos dos países do Golfo da Guiné. Em vez dos Estados regionais delegarem o direito de intervir no seu espaço de soberania para atores políticos internacionais, podem abrir mão de suas soberanias para a atuação de instituição regional com mais capacidade de unificar os interesses em comum e de promover a segurança regional de forma eficiente e efetiva. 


\section{6. \\ REFERÊNCIAS BIBLIOGRÁFICAS}

ALMEIDA, Eugênio Costa \& BERNARDINO, Luís Manuel Brás. A comissão do golfo da guiné e a zona de paz e cooperação do atlântico sul. Organizações interzonais para a persecução da segurança marítima na bacia meridional atlântica. Disponível em: http://www.revistamilitar.pt/artigo.php?art id=797. Acesso em: 3/12/2013.

ALI, Munae \&MURAD, Zahra. Unravelling Narratives of Piracy: Discourses of Somali Pirates.Darkmatter Journal, 2009, Issue-5, Pirates\&Piracy.

Universidad

AMARAL, Arthur Bernardes do. A Guerra ao Terror e a Tríplice Fronteira na Agenda de Segurança dos Estados Unidos. Dissertação de Mestrado Acadêmico, 2008. Pontifícia Universidade Católica do Rio de Janeiro. Brasil

ÂMBITO JURÍDICO. Disponível em:

http://www.ambitojuridico.com.br/site/index.php?n_link=revista_artigos_leitura\&artigo_id=6248 Acesso em: 25/06/2014.

AMUNWA, Ben. Counting the cost: corportations and human rights abuses in the Niger Delta. 2011.

Disponível em:http://platformlondon.org/2011/10/03/counting-the-costcorporations-and-human-rights-abuses-in-the-niger-delta/. Acesso em: $12 / 02 / 2015$.

ANDERSON, J.L. Piracy and World History: An Economic Perspective on Maritime Predation.Disponível em: Journal of World History, Vol. 6, No. 2 (Fall, 1995), pp. 175-199. University of Hawai'i Press. Disponível em: http://www.jstor.org/stable/20078637. Acesso em: 11/12/2013.

ANYIMADU, Adjoa. Maritime Security in the Gulf of Guinea: Lessons Learned from the Indian Ocean. Chatham House paper. Disponível em:

$<$ http://www.chathamhouse.org/sites/default/files/public/Research/Africa/0713pp maritimesecurity_0.pdf $>$. Acesso em: 07/02/2014.

ANYU, J. Ndumbe \& MOKI, Samuel. Africa: The Piracy Hot Spot and Its Implications for Global Security. Mediterranean Quarterly 20, no. 3, setembro de 2009, pp 95-121.

ARIWERIOKUMA, SOALA. The Political Economy of Oil and Gas in Africa: The Case of Nigeria.London: Routledge, 2009.

ASUNI, BURDIN Judith. Blood Oil in the Niger Delta. United States Institute of Peace, Special Report 229, August 2009. 
AUGÉ, Benjamin. Pillage et vandalisme dans le Delta du Niger. Hérodote ${ }^{\circ} 134$, La découverte, 3ème trimestre 2009,pp. 151-174,. Disponível em: http://www.herodote.org/IMG/pdf/2.pdf. Acesso em: 07/02/2014.

AWOUMOU, C. \& DAMIEN, Georges. Le Golfe de Guinée face aux convoitises. Présentation faite à la 11 ème Assemblée générale du CODESRIA, Maputo, 6-10 décembre 2005. Disponível em: www.codesria.org/IMG/pdf/awoumou.pdf. Acesso em: 08 de dezembro de 2013.

BALL, Jeffrey. Angola Possesses a Prize as Exxon, Rivals Stalk Oil.In: Wall Street Journal, 5 December 2005.

BALZACQ Thierry. La politique européenne de voisinage, un complexe de sécurité à géométrie variable. Cultures \& Conflits, $n^{\circ} 66$, été, 2007. p. 31-59. DOI : $10.4000 /$ conflits.2481

BARRIOS, Cristina. Fighting piracy in the Gulf of Guinea: Offshore and onshore. European Union Institute for Security Studies , 2013.

BATEMAN, Sam. "A New Dimension to Global Piracy - Increased Attacks in the Gulf of Guinea".RSIS Commentaries No. 112/2012. June 2012 .S. Rajaratnamschool F. international studies. Disponível em: www.rsis.edu.sg. Acesso em: 17/02/2014.

.Killing Pirates: Dilemma of Counter-piracy.RSIS

Commentaries, no. 6 (2011). Disponível em: http://hdl.handle.net/10220/7579. Acesso em: 17/02/2014.

BENY, Eduardo. A nova geopolítica do petróleo. Viseu: Novo Imbodeiro. 2007.

BIZOURAS, Nikolaos. "Piracy, State Capacity and Root Causes: Lessons from the Somali Experience and Policy Choice in the Gulf of Guinea." African Security Review, 2013: 1-17.

BUEGER, Christian. Contemporary Maritime Piracy as an Issue of Academic Inquiry.p.3. Paper presented at the bi-annual conference of the Standing Group for International Relations of the ECPR, Stockholm, September 2010, p. 3. Disponível em: www.Piracy-Studies.org. Acesso em: 21/02/2014.

BUZAN, Barry. Peoples States and fear: an agenda for international security studies in the post-cold War Era. Londres: Lynne Rienner Publisher, 1991.

BUZAN, Barry \& HANSEN, Lene. A evolução dos Estudos de Segurança Internacional. São Paulo: Editora Unesp, 2012.

BUZAN, Barry \& WÆVER, Ole. Regions and Powers: the structure of international security. Cambridge University Press, 2003.

BUZAN, Barry; WÆVER, Ole; WILDE, Jaap de.Security: a new framework for analysis. Boulder: Lynne Reinner Publishers, 1998. 
BURNLEY Terry. "Emory S. Land Completes Gulf of Guinea Deployment". In: Navy Newstand, 22 March 2005; U.S. European Command News Release.

BWELE, Charles. “Golfe de Guinée: anti-piraterie ou pétrostratégie ?". Electrosphère, 29 avril 2009. Disponível em: http://electrosphere.blogspot.com.br/2009/04/golfe-de-guinee-anti-piraterieou.html . Acesso em: 22/05/2013.

CARIOU P., MEIJA, M., WOLFF, F.C. Ship Piracy: Ship Type and Flag in Talley W.K. (eds), Maritime Safety, Security and Piracy. World Maritime University, Malmö, 2009.

CEPIK, Marco \& BORBA, Pedro. Crime organizado, Estado e Segurança internacional. Contexto internacional - vol. 33, n. 2, julho/dezembro 2011, pp131.

CHATHAM HOUSE. Oil and Elections: Prospects for the Resolution of Oil Conflict in the Niger Delta and Potential Impacts on the 2007 Elections. Meeting Report. London: Chatham House. 2006. Disponível em: http://www.chathamhouse.org.uk/research/africa/papers/view/-/id/355/. Acesso em: 17/02/2014.

CONVENÇÃO DO DIREITO SOBRE O MAR. 1982. Disponível em: http://www.fd.uc.pt/CI/CEE/OI/ISA/convencao_NU_direito_mar-PT.htm.

Acesso em: 28/12/2013.

COPINSCHI, Philippe. Rente pétrolière, géopolitique et conflits. Questions Internationales, n.2, juillet-août2003, p.39- 45.

CORMIER-SALEM, Marie-Christine e DAHOU, Tarik (org). Gouverner la mer. États, pirates, societies. Politique africaine $\mathrm{n}^{\circ} 116$ - décembre 2009. Introdução.

Disponível

em:

http://www.cmjornal.xl.pt/detalhe/noticias/outros/domingo/a-pirataria-em-altomar-ainda-existe. Acesso em: 27/01/2014.

DANIEL, Soni. Why Niger Delta oil theft can't stop - Boyloaf. Vanguard. 07 de setembro de 2013. Disponível em: $<$ http://www.vanguardngr.com/2013/09/whyniger-delta-oil-theft-cant-stop-boyloaf/\#sthash.a3zo29wR.dpuf $>$ Acesso em: $09 / 02 / 215$.

DAWDY, LEE, Shannon. Why Pirates Are Back. Annual Review of Law and Social Science.Vol. 7: 361-385 (Volume publication date December 2011)

First published online as a Review in Advance on August 23, 2011

Disponível em: http://www.lawsocsci.annualreviews.org. Acesso em: 07/09/2014.

\& BONNI Joe.Towards a General Theory of Piracy. Pirates and Piracy, Broadly Conceived. Anthropological Quarterly, Vol. 85, No. 3, p. 673-700, 2012. Institute for Ethnographic Research (IFER), George Washington University. 
DE CLERCK, Julie. "La sécurité en mer, un nouveau marché?". In: Conventions.Disponível em: http://convention-s.fr/decryptages/la-securite-enmer/. Acesso em: 08/02/2014.

DEUTSCH K. et al., Political Community and the North Atlantic Area. Princeton UP, 1957, p1-15.

DIALLO, ALPHA, Mamadou. A dinâmica da segurança regional na áfrica subsaariana: áfrica ocidental proto-complexos ou sub-complexo regional de segurança. In: Seminário de relação internacional: $1^{\circ}$ seminário nacional de pósgraduação/UFRGS.12 e 13 de julho de 2012

Duffield M (2001) Global Governance and the New Wars: The Merging of Development and Security. London/New York: Zed.pp.130-150.

(2010) The Liberal Way of Development and the DevelopmentSecurity Impasse: Exploring the Global Life-Chance Divide. Security Dialogue 41(1): 53-76.

DUQUE ESTRADA, Rodrigo \& PREUSSER, Fernando. 2013. O Processo de Securitização do Magreb-Sahel. Seminário brasileiro de estudos estratégicos internacionais (sebreei) o atlântico sul como eixo da inserção internacional do Brasil. 21 a 23 de maio Porto Alegre/RS, Brasil. Disponível em:

$<$ http://www.sebreei.eventos.dype.com.br/resources/anais/21/1365651980_ARQ

IVO_artigo_sebreei.pdf $>$. Acesso em: 17/01/2014.

ESCORREGA, FALCÃO,Luís Carlos. 2010. "Estratégia Americana para a África: A importância do Golfo da Guiné.” Revista Estratégia.

ESTRADA, DUQUE, R. E MATTOS (de) PREUSSER, Fernando. Realização: O Processo de Securitização do Magreb-Sahel. SEMINÁRIO BRASILEIRO DE ESTUDOS ESTRATÉGICOS INTERNACIONAIS (SEBREEI) GT. O Atlântico Sul como Eixo da Inserção Internacional do Brasil. 21 a 23 de Maio de 2013 Porto Alegre/RS, Brasil

ÉVORA, M. (2011). Que Regionalismo Securitário para a África Ocidental?ISEG (CESA): in Seminário sobre Ciências Sociais e Desenvolvimento em África. Disponível em: http://pascal.iseg.utl.pt/ cesa/files/Doc trabalho/18MaurinoEvora.pdf. Acesso dia 09/02/2015.

FIERKE, F. M. Critical Approaches to International Security. Cambridge: Polity Press, 2007.

FANCHETTE, S. « Le Delta du Niger (Nigeria) : rivalités de pouvoir, revendications territoriales et exploitation pétrolière ou les ferments de la violence ", Hérodote, La Découverte, Paris, 2e trimestre 2006.

FRYNAS, Jedrzej; George, BECK, P., Matthias, MELLAHI, Kamel.Maintaining corporate dominance after decolonization: the first mover advantage of Shell-BP 
in Nigeria”. In: Review of African Political Economy 27 (2000), p. 213-30.

PAULO, Manuel.A new scramble for african oil? historical, political, and business perspectives. In: African Affairs, 106/423, 229-251 2007. Published by Oxford University Press on behalf of Royal African Society.

GARY, Ian; KARL, Terry Lynn."O fundo do barril: o boom do petróleo em África e os Pobres”: CRS-Catholic Relief Services, 2003. Disponível em: $<$ www.earth.columbia.edu/.../Bottom_of_the_Barrel_Port_PDF.pdf $>$. Acesso em: 10 de setembro de 2013.

GHOSH, P. K. 2013.“Waiting to Explode: Piracy in the Gulf of Guinea". Paper nr. 46. Observer Research Foundation Occasional. Disponível em: http://www.observerindia.com/cms/export/orfonline/modules/occasionalpaper/atta chments/occasionalpaper46_1381300389613.pdf. Acesso em: 12/01/2015.

GROS, Jean-Germain. "Towards a taxonomy of failed states in the New World Order: decaying Somalia, Liberia, Rwanda and Haiti”. Third World Quarterly v. 17, n.3, p. 455-471, London, 1984.

Hansen, Stig Jarle. Piracy in the greater Gulf of Aden Myths, Misconception and Remedies. NIBR Report 2009:29. Norwegian Institute for Urban and Regional Research, 2009.

Disponível in: http://www.nibr.no/filer/2009-29-ny.pdf. Acesso em: 08/12/2014.

HETTNE, Björn \& SÖDERBAUM, Frederik. "Theorizing the rise of regionness". In: BRESLI, S., HUGHES, C., PHILIPPS, N. (eds). New regionalisms in the global political economy. London: Routledge. pp. 33-47. 1999.

HERZ, Monica. O tratamento de segurança regional pela disciplina de Relações Internacionais. $2005 . \quad$ Disponível em: $<$ http://www.scribd.com/doc/86585177/HERZ-2005-O-Tratamento-da-

Seguranca-Regional-pela-disciplina-de-Relacoes-Internacionais $>$. Acesso em: 13/08/ 2013.

HOBSBAWM, Eric J. Bandidos. Rio de Janeiro: Forense Universitária, 1976.

HOLMAN, Fenwick W. Piracy off Somalia. 2012. Briefings. Disponível in: http://www.fulcrum-maritime.com /Anti piracy Information. Acesso em: 05/01/2014.

HUYSMANS, Jef. The Politics of Insecurity: Fear, migration ansasylium in the EU. Londres: Routledge, 2006.

INTERNATIONAL CRISIS GROUP. Le golfe de guinée: la nouvelle zone à hautrisque. Rapport Afrique $\mathrm{N}^{\circ} 195$ - 12 décembre 2012.

INTERNATIONAL MARITIME BUREAU'S (IMB). Piracy and Armed Robbery against Ships Annual Reports.In: http://www.icc-ccs.org/piracy- 
reporting-centre. Acesso em: 03/01/2014.

JEUNE AFRIQUE.http://www.jeuneafrique.com/

JORNAL ALLAFRICA.West Africa:Gulf of Guinea - the New Flashpoint of

Piracy in Africa?Alex Benkenstein, 16 December 2013. http://allafrica.com/stories/201312171230.html. Acesso em: 24/04/2014.

JORNAL AFRICA RENEWAL. Disponível em: http://www.un.org/africarenewal/magazine/december-2013/piracy-west-africa. Acesso: 02/02/2014.

JORNAL LE MONDE. http://www.lemonde.fr/afrique/article/2008/11/19/faceaux-attaques-de-pirates-la-mobilisation-navale-internationale-montre-seslimites_1120301_3212.html. Artigo de ZECCHINI, Laurent. Acesso em: 23/03/2014.

JORNAL SLATE. Disponível em: http://www.slate.fr/story/83105/epicentrepiraterie-golfe-guinee. Ver artigo de JONHSON, Keith.

$<$ http://www.histoiredumonde.net/Pirate.html> Acesso em: 07/02/2014

JOSÉ, Joveta. A Política Externa de Angola: Novos Regionalismos e Relações Bilaterais com o Brasil (2011). Tese de doutorado. UFRGS. Disponível em: http://www.lume.ufrgs.br/bitstream/handle/10183/35078/000794257.pdf?se.

Acesso em: 14/02/2014.

KARL, L. Terry. The Paradox of Plenty. Berkeley, CA: University of California Press, 1997.

KLARE, Michael; VOLMAN, Daniel.The African "Oil Rush" and American National Security. In: Third World Quarterly, Volume 27, Issue 4 (May 2006).

KERR, Lucas. Petróleo e segurança internacional. Aspectos globais e regionais na África subsaariana. Dissertação de mestrado. Universidade Federal do Rio Grande Do Sul, Instituo de Filosofia e ciências humanas, Programa de pósgraduação em relações internacionais: Porto Alegre, 2007.

KIPRÉ Pierre. "Sur la périodisation de l'histoire de l'Afrique de l'Ouest: le Golfe De Guinée".Afrique \& histoire, n.1/2004 (vol. 2), p. 85-96. Disponível em $<$ www.cairn.info/revue-afrique-et-histoire-2004-1-page-85.htm $>$ Acesso em: $03 / 12 / 2013$.

K'NAAN.ON SOMALI.Pirates - There is a Reason Why This Started," Hard KnockTV, (30 Dec. 2008). Disponível em:

http://www.youtube.com/watch?v=UTxJL1QCe4U. Acesso 03/02/2014.

K'NAAN ON SOMALI. “Somali Pirates.” Indira Naidoo Harris, Host, The Current, CBC Radio One. (21 Nov. 2008). Disponível em: http://www.cbc.ca/thecurrent/2008/200811/20081121.html. Acesso: 03/02/2014. 
KOUNGOU, Leon. De La sécurisation à la "sécuritisation " du golfe de Guinée. Tribune n.480. Disponível em: <www.defnat.fr $>-18$ février 2014. Acesso em: 24/02/2014.

IBM (2012) Piracy and Armed Robbery against Ships. Annual Report 2011. London: International Maritime Bureau. Disponível em: ww.iccwbo.org/productsand-services/fighting-commercial-crime/imb-piracy-reporting-centre e http://www.iccwbo.org/news/ Acesso em: 25/06/2014

IMO (2011) International Conference on Piracy at Sea - Keynote Address, International Maritime Organization. Disponível em: $<$ http://www.imo.org/Pages/home.aspx $>$

$<$ http://www.imo.org/MediaCentre/SecretaryGeneral/SpeechesByTheSecretaryGe neral/Pages/International-Conference-on-Piracy-at-Sea-.aspx>. Acesso em: $25 / 06 / 2014$

LEESON, Peter. The Invisible Hook: The Hidden Economics of Pirates. Princeton :University Press.2009.

LUNTUMBUE, Michel. "Piraterie et insécurité dans le Golfe de Guinée : défis et enjeux d'une gouvernance maritime régionale". Note d'analysedu Groupe de recherche et d'informationsur la paix et la sécurité, 30 septembre 2011.

LYMAN, Michael; POTTER, Gary.Organized crime. Upper Saddle River: Prentice Hall, 2000.

MALAQUIAS A., 2012. 'Ask the Expert: The Growing Threat of Oil Pirates in West Africa's Gulf of Guinea'. Africa Center for Strategic Studies. Disponível em: http://africacenter.org/2012/03/ask-the-expert-the-growing-threatof-oil-pirates-in-west-africa $\% \mathrm{E} 2 \% 80 \% 99$ s-gulf-of-guinea/. Acesso em: 09/02/2014.

MAZRUI, A. "The blood of experience: The failed state and political collapse in Africa" in: World Policy Journal, vol 12, n²1, 1995, pp. 28-34.

MCSWEeney B. 1999, Security, Identity and Interests: a Sociology of International Relations, Cambridge, Cambridge University Press.

MELOUPOU, Jean-Pierre e NGOUTSOP, TAMEKEN, Moïse.Piraterie et Mécanismes psychosociologiques de défense dans le Golfe de Guinée. Revues sociologiques. Disponível em: http://sociologies.revues.org/4155?lang=en. Acesso em: 03/01/2014.

MIDDLETON, Roger. Piracy in Somalia. Threatening Global Trade, Feeding Local Wars.Briefing Paper, Africa Programme. Chatham House, October 2008, p. $1-12$.

MIGDAL J., Strong Societies and Weak States: State-Society Relations and State Capabilities in the Third World.Princeton, New Jersey, 1998. 
MIRABEAU, NCHARE, N., Théophile.Initiatives diplomatiques et occupation de l'espace africain: le cas du golfe de guinée (2001-2008). Mémoire de DEA en science politique.Sousladirection de Fogue T. Alain. Université de Yaoundé II. Année académique: 2008-2009.

MONIÉ, F. Petróleo, desenvolvimento e dinâmicas especiais na África subsaariana. In: Monié, Frédéric, BINSZTOK, Jcob (org.): Geografia e geopolítica do petróleo, Rio de janeiro: Mauad X, p.201-236.2012.

MONTCLOS, Marc-Antoine Pérouse de. A pirataria marítima na Nigéria - um fenômeno antigo em vias de modernização. Relações Internacionais, n. 31, set.2011. Disponível em: http://www.scielo.oces.mctes.pt/scielo.php?pid=S164591992011000300008\&script=sci_arttext. Acesso em:18/12/2013.

MOTTA, Bruno \& DUTRA, Gabriela. Violência armada organizada: um fenômeno que ameaça fronteiras estatais.Oikos, v. 9, n. 1, p. 85-105, 2010. Disponível http://www.revistaoikos.org/seer/index.php/oikos/article/viewFile/173/132Acesso em: 16/02/2014.

MURPHY, Martin N. Small Boats, Weak States, Dirty Money: Piracy \& Maritime Terrorism in the Modern World, London, Hurst \& Company.2009.

NDOUTOUME, N., J. 2010. Terrorisme et piraterie: quelle sécurité pour les mers du Golfe de Guinée (p.159-181). In: Piraterie et terrorisme: de nouveaux défis sécuritaires en Afrique centrale. Ntuda Ebode Joseph Vincent (cord.). Presses Universitaires d'Afrique B.P. 8106 Yaoundé - Cameroun.

NEOCELOUS, M. (2008). Critique of security. Edinburgh: Edinburgh University Press.

NEPAD (2005) African Post-Conflict Reconstruction Policy Framework. Johannesburg: The New Partnership for Africa's Development.

NGOM NDOUTOUME, Jonathan. "Le Golfe de Guinéeau centre desconvoitises mondiales". In: Diplomatie, no. 56, mai-juin, 2012, p. 72-74.

NINCIC, Donna. "State Failure and the Re-Emergence of Martime Piracy." Paper Prepared for Presentation atthe 49th Annual Convention of the International Studies Association, March 26-29, San Francisco,CA, 2008: 1-34.

NTOUTOUME, Loic. Gabon Review.In :à la une, afrique. Jeudi 27 juin 2013. Disponível em: <http://gabonreview.com/blog/les-decisions-du-sommetsur-la-piraterie-maritime-de-yaounde/>Acesso em:20/01/2014

NTUDA EBODÉ, Joseph, Vincent. La nouvelle posture géopolitique Du Cameroun et La lutte contre La piraterie dans le Golfe de Guinée. P. 43- In: Piraterie et terrorisme: de nouveaux défis sécuritaires en Afrique Centrale. Presses Universitaires d'Afrique: Yaoundé - Cameroun. 2010. 
OLIVEIRA, Gilberto. A Articulação da Pirataria Somali através do "Nexo" Segurança-Desenvolvimento: "Paz Liberal" ou "Guerra Liberal". Disponível em: http://www.ces.uc.pt/coimbrac/pages/pt/comunicacoes-e- posters/601--gilberto-oliveira.php. Comunicação apresentada no III Colóquio de Doutorandos/as do CES-2012.

Economia política da pirataria na Somália: bases para uma abordagem transformativa. Univ. Rel. Int., Brasília, v. 8, n. 2, p. 23-51, jul./dez. 2010.

- A interface interna-externa da segurança no espaço oceânico 0 caso da criminalidade marítima. Relações Internacionais no.40 Lisboa dez. 2013

ONUF, Nicholas G. Constructivism: A User's Manual. New York: Routledge, (1998).

Making sense, making word: constructivism in social theory and international relations. New York: Routledge, 2013.

ONUOHA, C., Freedom. "Piracy and Maritime Security in the Gulf of Guinea: Nigeria as a Microcosm". Al Jazeera Centre for Studies. Junho de 2012. Disponível

em: http://studies.aljazeera.net/ResourceGallery/media/Documents/2012/6/12/201261 294647291734Piracy\%20and\%20Maritime\%20Security\%20in\%20the\%20Gulf $\%$ 20of\%20Guinea.pdf. Acesso em: 12/12/2014.

2013. "Oil piracy in the Gulf of Guinea". Conflict trends I 35. Issue 4.

ORGANIZAÇÃO DAS NAÇÕES UNIDAS. The globalization of crime: a transnational organized crime threat assessment. Nova Iorque: UNODC, 2010 .

Conselho de Segurança das Nações Unidas. Resolução 1373. 28 set. 2001. Resolução 1817. 11 jun. 2008. Resolução 1890. 8 out. 2009a.

Statement by the President of

the Security Council. 8 dez. 2009b. Organization of Petroleum Exporting Countries. OPEC: Annual Statistical Bulletin, 2013. Disponível em: http://www.opec.org/opec_web/static files project/media/downloads/publications /ASB2013.pdf

OYEFUSI, Aderoju.Oil and the Propensity to Armed Struggle in the Niger Delta Region of Nigeria.World Bank Policy Research Working Paper 4194, April 2007.The Post-Conflict Transitions Working Paper Series. Disponível em: http://econ.worldbank.org. Acesso em: 10/12/2014.

ORTOLLAND, Didier \& PIRAT Jean-Pierre.Atlas des espacesmaritimes. Paris. 2010, p. 58. 
PATRICK, S. "Weak States and Global Threats: Fact or Fiction?". The Washington Quarterly.v.29, n. 2, p. 27-53. Washington. 2006.

PLAUT, Martin. "Pirates 'Working with Islamists", BBC News. Disponível em: http://news.bbc.co.uk/2/hi/7737375.stm (19 Nov. 2008).

PLEMING, Sue. “Clinton Says World Must End 'Scourge' of Piracy,"Reuters. Disponível em: http://www.reuters.com/article/latestCrisis/idUSN08546967 (8 Apr. 2008).

PENNELL, C.R. Bandits at Sea: $\boldsymbol{A}$ Pirates Reader. Edited by C.R Pennell. New York: New York University Press, 2001.p3-25.

PÉROUSE DE MONTCLOS, Marc-Antoine. "Migração e crise urbanização forçada. África subsaariana uma perspectiva histórica".In: Autrepart, n.55 (2010), p.3-18.

PUGH, M \&COOPER, N. (2004). War Economies in a Regional Context: Challenges of Transformation. International Peace Academy. Lynne Rienner Publishers, Inc.

RADIO FRANCE INTERNATIONAL.http://www.rfi.fr/afrique/20131203piraterie-maritime-france-societes-securite-privees-somalie-golfe-guinee/. Acesso: $14 / 01 / 2014$.

RÉMY, Jean-Philippe, Une nouvelle « guerre du pétrole » menace le Nigeria, Le Monde, 1er avril 2010, p.6.

ROSS Margaret. “Africa's Elephants of the Deep”. In: The Lamp (Exxon Corp), Winter 1998-99, p. 4.

RIOLS, Alexis. "Piraterie et brigandage maritime dans le Golfe de Guinée". In: Centre d'études supérieures de la marine, Paris, 2011.

RISSO, Patricia. Cross-Cultural Perceptions of Piracy: Maritime Violence in the Western Indian Ocean and Persian Gulf Region during a Long Eighteenth Century. In: Journal of World History, Vol. 12, No. 2 (Fall, 2001), pp. 293-319. University of Hawai'i Press. Disponível em: http://www.jstor.org/stable/20078911. Acesso em: 11/12/2013.

SABELO J. Ndlovu-Gatsheni \& OJAKOROTU Victor, 'Surveillance Over a Zone of conflict: AFRICOM and the Politics of Securitization in Africa,' in Journal of Pan- African Studies, 3 (6) (March 2010), pp. 94-110.

SAMATAR, A., Ismail, LINDBERG Mark e MAHAYNI Basil.The Dialectics of Piracy in Somalia : the rich versus the poor. Third World Quarterly, Vol. 31, No. 8, 2010, pp 1377-1394. 
Vasilis. The Effect of Maritime Piracy on Greek Shipping. Paper. 05/2013. Apresentado no4th International Symposiumof Maritime SafetySecurity \& Environmental Protection, $30^{\text {th }}$ e $31^{\text {st }}$ of May 2013. Disponível em: http://www.massep.gr/speakers-and-presentations. Acesso em: 25/02/2014.

SARO-WIWA, K.B.A Month and A Day: A Detention Diary. Harmondsworth: Penguin Books, 1995.

SCHMITT, Jean-Claude. A história dos marginais. In: LE GOFF, Jacques. A história nova. São Paulo: Martins Fontes, 1993. p. 261-290.

"Africom: Mode d'emploidu nouveau cheval de Troie". Interview publicada em «EUCOM Leader calls Africa Global Strategic Imperative» in Revista defenselink.mil.08/03/2006.

"More than Humanitarianism: A Strategic U. S. Approach Toward Africa". Chairs: Anthony Lake and Christina Tood Whitman. Independent Task Force report n.56.

SONI, Daniel. Why Niger Delta oil theft can't stop - Boyloaf.Vanguard, 07 de setembro de 2013. Disponível em: $<$ http://www.vanguardngr.com/2013/09/whyniger-delta-oil-theft-cant-stop-boyloaf/\#sthash.a3zo29wR.dpuf $>$ Acesso em: $02 / 12 / 2014$.

TANNO, Grace. 2003. "A contribuição de Escola de Copenhague aos Estudos de Segurança Internacional". In: Revista Contexto Internacional. Vol. 25, n. 1, 47-80. Disponível em: http://www.scielo.br/pdf/cint/v25n1/v25n1a02.pdf. Acesso em: 04/01/2014.

TOBY Archer, TIHOMIR Popovic. The Trans-Saharan Counter-Terrorism Initiative. The US War on Terrorism in North Africa. 2007.

FIIA (UPI) Reports \& Analyses. Finnish Institute of International Affairs (FIIA), Helsinki, Finland.

THOMSON, Janice E. Mercenaries, Pirates, and Sovereigns: State-Building and Exterritorial Violence in Early Modern Europe. United Kingdom: Princeton University Press, 1994.

TSVetKova, V., Bilyana.Securitizing Piracy Off the Coast of Somalia. Central European Journal of International \& Security Studies, volume 3, issue 1, 2009, pp. 44-63. Disponível em: http://static.cejiss.org/data/uploaded/1383601451477445/cejiss_vol3_issue1_full_ version.pdf. Acesso em: 17/02/2013.

ULLMAN, Richard. "Redefining Security". International Security, Vol. 8, n. 1. 1983, p.129-153. Disponível em: http://www.jstor.org/stable/2538489 . Acesso em: 20/08/2014.

UKIWO, Ukoha. From "pirates" to "militants": a historical perspective on anti-state and anti-oil company mobilization among the ijaw of warri, 
western niger delta. African Affairs, 106/425, 587-610. 2007. Oxford University Press on behalf of Royal African Society.

UKEJE, Charles e MVOMO ELA, Wullson. African approaches to maritime security. The gulf of Guinea. Nigeria: Friedrich Ebert Stitfund. 2013.

VIRCOULON, Thierry.Golfe de Guinée : la régionalisation de la sécurité maritime est-elle la solution contre la piraterie ? 04/09/2015. International Crisis Group.

Disponível em: http://blog.crisisgroup.org/africa/2014/09/04/golfe-de-guinee-laregionalisation-de-la-securite-maritime-est-elle-la-solution-contre-la-piraterie/. Acesso em: 02/02/2015.

VOLMAN, Daniel. The Military Dimensions of Africa's New Status in Global Geopolitics. Paper Prepared for Nordic Africa Institute Conference: "ChinaIndia-Africa Relations: New Strategic Encounters", Uppsala, Sweden, 22-23 September 2008. Disponível em: http://concernedafricascholars.org/africansecurity-research-project/?p=49. Acesso em: 24/02/2014.

VRËY, François. "Bad order at sea: From the Gulf of Aden to the Gulf of Guinea." African Security Review, 2010: 17-30.

WALDO, ABSHIR, Mohamed. "The two piracies in Somalia: why the world ignores the other?" agosto de 2009. Disponível em:http://wardheernews.com/Articles_09/Jan/Waldo/08 The two piracies in So malia.html. Acesso em: 23/02/2014.

WATTS. Mickael. A Tale of Two Gulfs: Life, Death, and Dispossession along Two Oil Frontiers. In: American Quartely, Vol.64, N.3, Agosto de 2012. P.437467.

YANG, Catherine.Less blood for oil, Nigeria's fragile amnesty, Harvard International Review winter 2010.

YATES, A., Douglas. The Rentier State in Africa: Oil rent dependency and neocolonialism in the Republic of Gabonin Africa. World Press: Trenton NJ. 1996.

ZARTMAN W. Collapsed States, the Disintegration and Restoration of Legitimate Authority.London, Lynne Rienner Publishes, 1995. 